$2{ }^{2}$

f Prepared in cogperation with the Osage Nation

Description of Landscape Features, Summary of Existing

Hydrologice Data, and Identification of Data Caps for the Osage Ifatjon, Northeastem OKJahoma, 1890-2012

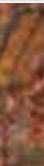




\section{Front cover:}

Background, Sand Creek in Osage Hills State Park, Oklahoma, 2013; photograph by Stan Paxton.

Top, Unnamed tributary of the Arkansas River near Cleveland, Okla., 2013; photograph by Stan Paxton.

Bottom, Bird Creek near Pawhuska, Okla., 2013; photograph by Stan Paxton.

\section{Back cover:}

Left, Arkansas River near Cleveland, Okla., 2013; photograph by Stan Paxton.

Right, Arkansas River near Ralston, Okla., 2013; photograph by Stan Paxton.

Bottom, U.S. Geological Survey drilling rig near Hominy, Okla., 2013; photograph by Stan Paxton. 


\section{Description of Landscape Features, Summary of Existing Hydrologic Data, and Identification of Data Gaps for the Osage Nation, Northeastern Oklahoma, 1890-2012}

By William J. Andrews and S. Jerrod Smith

Prepared in cooperation with the Osage Nation

Scientific Investigations Report 2014-5134 


\section{U.S. Department of the Interior \\ SALLY JEWELL, Secretary}

\section{U.S. Geological Survey \\ Suzette M. Kimball, Acting Director}

\section{U.S. Geological Survey, Reston, Virginia: 2014}

For more information on the USGS — the Federal source for science about the Earth, its natural and living resources, natural hazards, and the environment, visit http://www.usgs.gov or call 1-888-ASK-USGS.

For an overview of USGS information products, including maps, imagery, and publications, visit http://www.usgs.gov/pubprod

To order this and other USGS information products, visit http://store.usgs.gov

Any use of trade, firm, or product names is for descriptive purposes only and does not imply endorsement by the U.S. Government.

Although this information product, for the most part, is in the public domain, it also may contain copyrighted materials as noted in the text. Permission to reproduce copyrighted items must be secured from the copyright owner.

Suggested citation:

Andrews, W.J., and Smith, S.J., 2014, Description of landscape features, summary of existing hydrologic data, and identification of data gaps for the Osage Nation, northeastern Oklahoma, 1890-2012: U.S. Geological Survey Scientific Investigations Report 2014-5134, 53 p., http://dx.doi.org/10.3133/sir20145134.

ISSN 2328-031X (print)

ISSN 2328-0328 (online) 


\section{Acknowledgments}

The authors wish to thank the Osage Nation Congress along with Jann Jones and other Osage Nation staff for supporting this work and providing technical advice. The authors also appreciate assistance provided by Erwin Pino, DeLon Flinchum, and Matt Stover of Chaparral Energy, Inc., and Kyle Murray of the Oklahoma Geological Survey for estimating saline-water injection in the Osage Nation. 



\section{Contents}

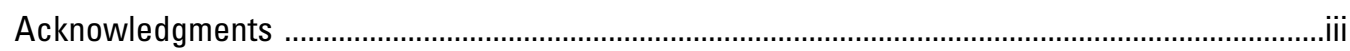

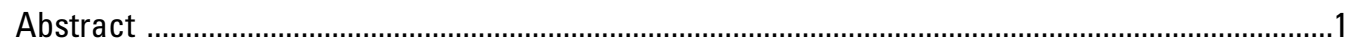

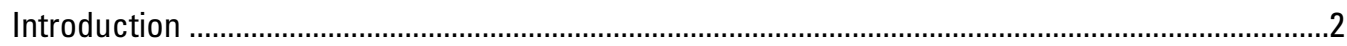

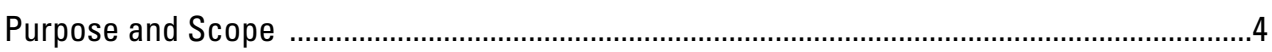

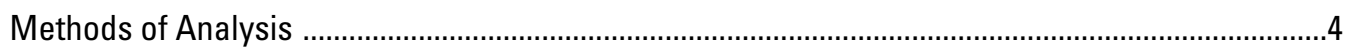

Selection and Analysis of Climatic, Geographic, and Hydrogeologic Data ............................4

Selection and Analysis of Streamflow and Surface-Water-Quality Data ...............................4

Selection and Analysis of Groundwater-Quality Data ..............................................................

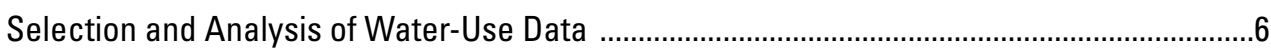

Quality Assurance ...............................................................................................................

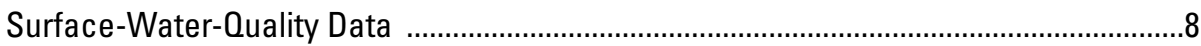

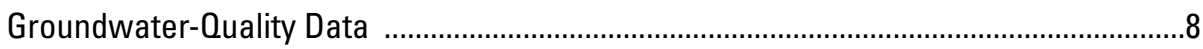

Description of Landscape Features of the Study Area ..............................................................

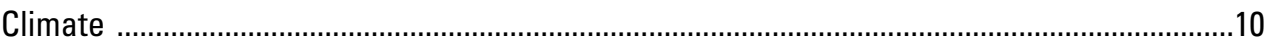

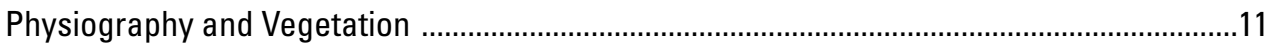

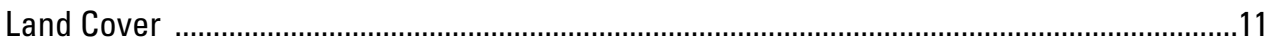

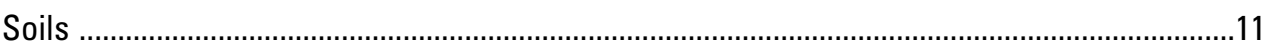

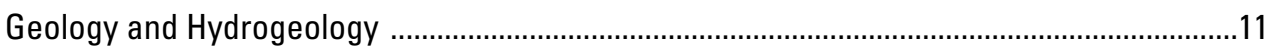

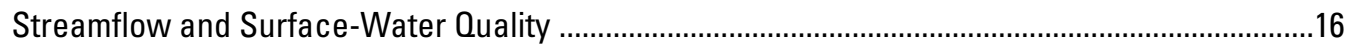

Long-Term Trends and Seasonality of Streamflow .........................................................16

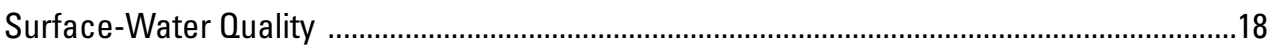

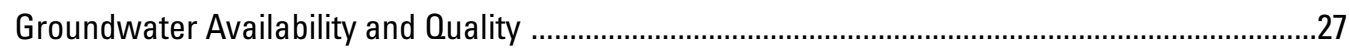

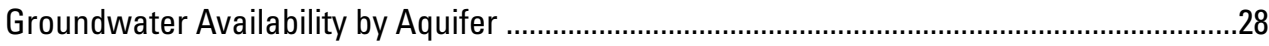

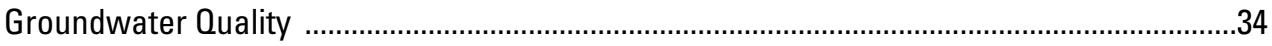

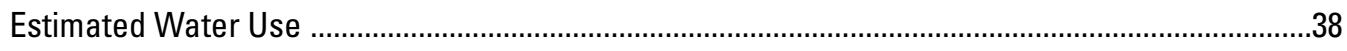

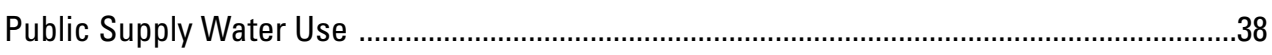

Domestic Self-Supplied Water Use .................................................................................

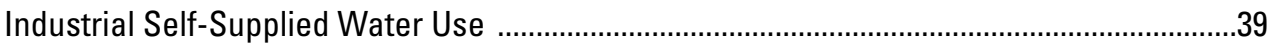

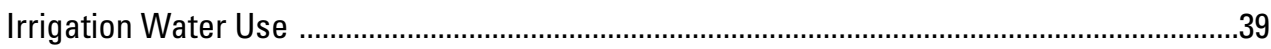

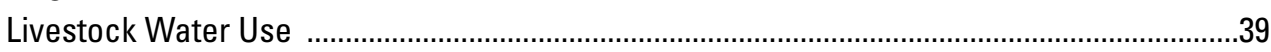

Aquaculture Water Use .............................................................................................

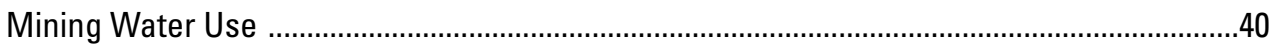

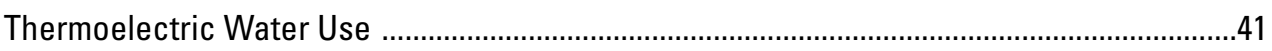

Water Use for All Purposes .................................................................................................. 41

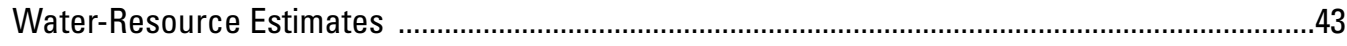

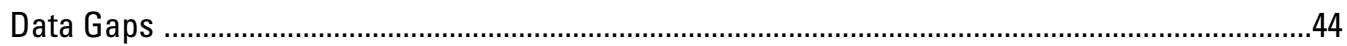

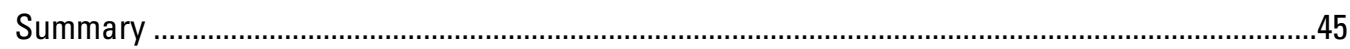

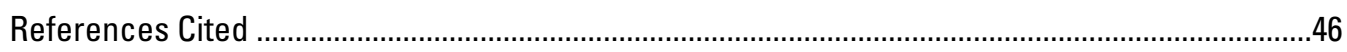

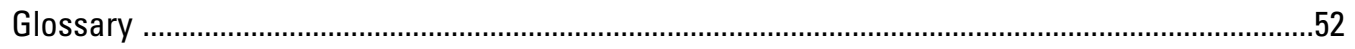




\section{Figures}

1. Map showing locations of selected geographic features of the Osage Nation, northeastern Oklahoma

2. Graphs showing climate data from three selected weather stations in the Osage Nation, northeastern Oklahoma, 1970 through 2012

3. Map showing land cover and percentages of land-cover classes in the 0sage Nation, northeastern Oklahoma, 2006

4. Map showing generalized soil groups in the Osage Nation, northeastern Oklahoma

5. Map showing surface geology in the Osage Nation, northeastern Oklahoma

6. Graphs showing trends in monthly mean streamflow at three long-term streamflow-gaging stations in or near the Osage Nation, northeastern Oklahoma, October 1976 through September 2012

7. Boxplots showing distributions of monthly mean streamflow by season at three streamflow-gaging stations in the Osage Nation, northeastern Oklahoma, October 1976 through September 2012

8. Boxplots showing dissolved oxygen concentration in surface-water samples collected at five sites in the Osage Nation, northeastern Oklahoma, 1999 through 2012

9. Boxplots showing total dissolved solids concentration in surface-water samples collected at five sites in the Osage Nation, northeastern Oklahoma, 1999 through 2012

10. Graph showing total dissolved solids concentration with streamflow at five sites in the Osage Nation, northeastern Oklahoma, 1999 through 2012

11. Map showing chloride concentrations measured downstream of selected basins in the Osage Nation, northeastern Oklahoma, 1999

12. Map showing locations of petroleum and natural-gas wells drilled in the Osage Nation, northeastern Oklahoma, as of 2002

13. Boxplots showing dissolved chloride in surface-water samples collected at five sites in the Osage Nation, northeastern Oklahoma, 1999 through 2012

14. Graph showing dissolved chloride concentration with streamflow at five sites in the Osage Nation, northeastern Oklahoma, 1999 through 2012

15. Boxplots showing dissolved phosphorus in surface-water samples collected at two sites in the Osage Nation, northeastern Oklahoma, 1999 through 2012

16. Graph showing dissolved phosphorus concentration with streamflow at two sites in the Osage Nation, northeastern Oklahoma, 1999 through 2012

17. Map showing principal aquifers and locations of 79 wells having depth-towater measurements made by the U.S. Geological Survey in the Osage Nation, northeastern Oklahoma, as of 2012

18. Map showing sand thickness of the unconfined Vamoosa-Ada aquifer in the Osage Nation, northeastern Oklahoma

19. Map showing water-table elevation in the unconfined Vamoosa-Ada aquifer in the Osage Nation, northeastern Oklahoma, as of 1975

20. Map showing altitude of the base of freshwater in the Vamoosa-Ada aquifer in the Osage Nation, northeastern Oklahoma, as of 1975

21. Cross sections showing sandstone layers and hydrogeologic boundaries in the Vamoosa-Ada aquifer in the Osage Nation, northeastern Oklahoma 
22. Map showing locations of wells sampled for water quality in the Osage Nation, northeastern Oklahoma, 1972 through 1997.

23. Boxplots showing total dissolved solids concentration by aquifer in the Osage Nation, northeastern Oklahoma, 1972 through 1997

24. Boxplots showing dissolved chloride concentration in groundwater samples by aquifer in the Osage Nation, northeastern Oklahoma, 1972 through 1997

25. Diagram showing the general pattern of groundwater recharge and discharge to streams and wells

26. Boxplots showing total phosphorus concentration by aquifer in the Osage Nation, northeastern Oklahoma, 1972 through 1993

27. Bar graph showing estimated freshwater use, by purpose and source, in the Osage Nation, northeastern Oklahoma, 1890 through 2010

28. Bar graph showing estimated fresh surface-water and groundwater use by source in the Osage Nation, northeastern Oklahoma, 1890 through 2010

\section{Tables}

1. Names and locations of selected streamflow-gaging stations in the Osage Nation, northeastern Oklahoma, 1982 through 2013

2. Names and locations of selected surface-water-quality sites sampled in the Osage Nation, northeastern Oklahoma, 1999 through 2012.

3. Relative percent differences of surface-water-quality data between field surface-water samples and field-replicate surface-water samples collected by the U.S. Geological Survey in the Osage Nation, northeastern Oklahoma, 2004 through 2005

4. Selected constituent concentrations measured in a blank water-quality sample associated with surface-water samples collected by the U.S. Geological Survey in the Osage Nation, northeastern Oklahoma, 2005

5. Relative percent differences of groundwater-quality data between field groundwater samples and field-replicate groundwater samples collected by the U.S. Geological Survey in the Osage Nation, northeastern Oklahoma, 1997

6. Selected constituent concentrations measured in blank water-quality samples associated with groundwater samples collected by the U.S. Geological Survey in the Osage Nation, northeastern Oklahoma, 1997

7. Major stratigraphic units in the Osage Nation, northeastern Oklahoma ........................15

8. Properties of freshwater aquifers underlying the Osage Nation, northeastern Oklahoma

9. Quality of 894 brine samples collected from petroleum and natural-gas wells in the Osage Nation, northeastern Oklahoma, 1939 through 1980

10. Estimated human population and population water sources in the Osage Nation, northeastern Oklahoma, 1890 through 2010

11. Estimated fresh surface-water use, by purpose, in the Osage Nation, northeastern Oklahoma, 1890 through 2010

12. Estimated fresh groundwater use, by purpose, in the Osage Nation, northeastern Oklahoma, 1890 through 2010

13. Estimated saline-groundwater reinjection related to petroleum and natural-gas extraction in the Burbank Oil Field, Osage Nation, northeastern Oklahoma, 1950 through 2012 


\section{Conversion Factors}

Inch/Pound to SI

\begin{tabular}{|c|c|c|}
\hline Multiply & By & To obtain \\
\hline \multicolumn{3}{|c|}{ Length } \\
\hline inch (in.) & 2.54 & centimeter $(\mathrm{cm})$ \\
\hline inch (in.) & 25.4 & millimeter $(\mathrm{mm})$ \\
\hline foot $(\mathrm{ft})$ & 0.3048 & meter $(\mathrm{m})$ \\
\hline mile (mi) & 1.609 & kilometer $(\mathrm{km})$ \\
\hline \multicolumn{3}{|c|}{ Area } \\
\hline acre & 4,047 & square meter $\left(\mathrm{m}^{2}\right)$ \\
\hline acre & 0.004047 & square kilometer $\left(\mathrm{km}^{2}\right)$ \\
\hline square foot $\left(\mathrm{ft}^{2}\right)$ & 0.09290 & square meter $\left(\mathrm{m}^{2}\right)$ \\
\hline square inch $\left(\mathrm{in}^{2}\right)$ & 6.452 & square centimeter $\left(\mathrm{cm}^{2}\right)$ \\
\hline square mile $\left(\mathrm{mi}^{2}\right)$ & 2.590 & square kilometer $\left(\mathrm{km}^{2}\right)$ \\
\hline \multicolumn{3}{|c|}{ Volume } \\
\hline $\begin{array}{l}\text { barrel (bbl), (petroleum, } \\
1 \text { barrel=42 gal) }\end{array}$ & 0.1590 & cubic meter $\left(\mathrm{m}^{3}\right)$ \\
\hline gallon (gal) & 3.785 & liter $(\mathrm{L})$ \\
\hline million gallons (Mgal) & 3,785 & cubic meter $\left(\mathrm{m}^{3}\right)$ \\
\hline cubic foot $\left(\mathrm{ft}^{3}\right)$ & 0.02832 & cubic meter $\left(\mathrm{m}^{3}\right)$ \\
\hline acre-foot (acre-ft) & 1,233 & cubic meter $\left(\mathrm{m}^{3}\right)$ \\
\hline \multicolumn{3}{|c|}{ Flow rate } \\
\hline cubic foot per second $\left(\mathrm{ft}^{3} / \mathrm{s}\right)$ & 0.02832 & cubic meter per second $\left(\mathrm{m}^{3} / \mathrm{s}\right)$ \\
\hline gallon per minute (gal/min) & 0.06309 & liter per second $(\mathrm{L} / \mathrm{s})$ \\
\hline gallon per day (gal/d) & 0.003785 & cubic meter per day $\left(\mathrm{m}^{3} / \mathrm{d}\right)$ \\
\hline million gallons per day (Mgal/d) & 0.04381 & cubic meter per second $\left(\mathrm{m}^{3} / \mathrm{s}\right)$ \\
\hline \multicolumn{3}{|c|}{ Mass } \\
\hline pound, avoirdupois (lb) & 0.4536 & kilogram $(\mathrm{kg})$ \\
\hline ton, short $(2,000 \mathrm{lb})$ & 0.9072 & megagram (Mg or tonne) \\
\hline \multicolumn{3}{|c|}{ Specific capacity } \\
\hline $\begin{array}{l}\text { gallon per minute per foot } \\
{[(\mathrm{gal} / \mathrm{min}) / \mathrm{ft}]}\end{array}$ & 0.2070 & $\begin{array}{l}\text { liter per second per meter } \\
{[(\mathrm{L} / \mathrm{s}) / \mathrm{m}]}\end{array}$ \\
\hline \multicolumn{3}{|c|}{ Hydraulic conductivity } \\
\hline foot per day (ft/d) & 0.3048 & meter per day $(\mathrm{m} / \mathrm{d})$ \\
\hline \multicolumn{3}{|c|}{ Transmissivity* } \\
\hline foot squared per day $\left(\mathrm{ft}^{2} / \mathrm{d}\right)$ & 0.09290 & meter squared per day $\left(\mathrm{m}^{2} / \mathrm{d}\right)$ \\
\hline
\end{tabular}


SI to inch/pound

\begin{tabular}{|c|c|c|}
\hline Multiply & By & To obtain \\
\hline \multicolumn{3}{|c|}{ Length } \\
\hline centimeter $(\mathrm{cm})$ & 0.3937 & inch (in.) \\
\hline millimeter $(\mathrm{mm})$ & 0.03937 & inch (in.) \\
\hline meter $(\mathrm{m})$ & 0.3048 & foot $(\mathrm{ft})$ \\
\hline kilometer $(\mathrm{km})$ & 0.6214 & mile (mi) \\
\hline \multicolumn{3}{|c|}{ Area } \\
\hline square meter $\left(\mathrm{m}^{2}\right)$ & 0.0002471 & acre \\
\hline square kilometer $\left(\mathrm{km}^{2}\right)$ & 2.471 & acre \\
\hline square meter $\left(\mathrm{m}^{2}\right)$ & 10.76 & square foot $\left(\mathrm{ft}^{2}\right)$ \\
\hline square centimeter $\left(\mathrm{cm}^{2}\right)$ & 6.452 & square inch $\left(\mathrm{in}^{2}\right)$ \\
\hline square kilometer $\left(\mathrm{km}^{2}\right)$ & 0.3861 & square mile $\left(\mathrm{mi}^{2}\right)$ \\
\hline \multicolumn{3}{|c|}{ Volume } \\
\hline cubic meter $\left(\mathrm{m}^{3}\right)$ & 6.289 & $\begin{array}{l}\text { barrel (bbl), (petroleum, } \\
1 \text { barrel=42 gal) }\end{array}$ \\
\hline liter $(\mathrm{L})$ & 0.2642 & gallon (gal) \\
\hline cubic meter $\left(\mathrm{m}^{3}\right)$ & 0.0002642 & million gallons (Mgal) \\
\hline cubic meter $\left(\mathrm{m}^{3}\right)$ & 35.31 & cubic foot $\left(\mathrm{ft}^{3}\right)$ \\
\hline cubic meter $\left(\mathrm{m}^{3}\right)$ & 0.0008107 & acre-foot (acre-ft) \\
\hline \multicolumn{3}{|c|}{ Flow rate } \\
\hline cubic meter per second $\left(\mathrm{m}^{3} / \mathrm{s}\right)$ & 35.31 & cubic foot per second $\left(\mathrm{ft}^{3} / \mathrm{s}\right)$ \\
\hline liter per second $(\mathrm{L} / \mathrm{s})$ & 15.85 & gallon per minute (gal/min) \\
\hline cubic meter per day $\left(\mathrm{m}^{3} / \mathrm{d}\right)$ & 264.2 & gallon per day (gal/d) \\
\hline cubic meter per second $\left(\mathrm{m}^{3} / \mathrm{s}\right)$ & 22.83 & million gallons per day (Mgal/d) \\
\hline \multicolumn{3}{|c|}{ Mass } \\
\hline kilogram $(\mathrm{kg})$ & 2.205 & pound, avoirdupois (lb) \\
\hline megagram (Mg or tonne) & 1.102 & ton, short $(2,000 \mathrm{lb})$ \\
\hline \multicolumn{3}{|c|}{ Specific capacity } \\
\hline $\begin{array}{l}\text { liter per second per meter } \\
{[(\mathrm{L} / \mathrm{s}) / \mathrm{m}]}\end{array}$ & 4.831 & $\begin{array}{l}\text { gallon per minute per foot } \\
{[(\mathrm{gal} / \mathrm{min}) / \mathrm{ft}]}\end{array}$ \\
\hline \multicolumn{3}{|c|}{ Hydraulic conductivity } \\
\hline meter per day $(\mathrm{m} / \mathrm{d})$ & 3.281 & foot per day (ft/d) \\
\hline \multicolumn{3}{|c|}{ Transmissivity* } \\
\hline meter squared per day $\left(\mathrm{m}^{2} / \mathrm{d}\right)$ & 10.76 & foot squared per day $\left(\mathrm{ft}^{2} / \mathrm{d}\right)$ \\
\hline
\end{tabular}

Temperature in degrees Celsius $\left({ }^{\circ} \mathrm{C}\right)$ may be converted to degrees Fahrenheit $\left({ }^{\circ} \mathrm{F}\right)$ as follows:

${ }^{\circ} \mathrm{F}=\left(1.8 x^{\circ} \mathrm{C}\right)+32$

Temperature in degrees Fahrenheit $\left({ }^{\circ} \mathrm{F}\right)$ may be converted to degrees Celsius $\left({ }^{\circ} \mathrm{C}\right)$ as follows:

${ }^{\circ} \mathrm{C}=\left({ }^{\circ} \mathrm{F}-32\right) / 1.8$

Vertical coordinate information is referenced to the North American Vertical Datum of 1988 (NAVD 88).

Horizontal coordinate information is referenced to the North American Datum of 1983 (NAD 83). 
Altitude, as used in this report, refers to distance above the vertical datum.

*Transmissivity: The standard unit for transmissivity is cubic foot per day per square foot times foot of aquifer thickness [(ft $\left.\left.\mathrm{ft}^{3} \mathrm{~d}\right) / \mathrm{ft}^{2}\right] \mathrm{ft}$. In this report, the mathematically reduced form, foot squared per day $\left(\mathrm{ft}^{2} / \mathrm{d}\right)$, is used for convenience.

Specific conductance is given in microsiemens per centimeter at 25 degrees Celsius $(\mu \mathrm{S} / \mathrm{cm}$ at $\left.25^{\circ} \mathrm{C}\right)$.

Concentrations of chemical constituents in water are given either in milligrams per liter (mg/L) or micrograms per liter $(\mu \mathrm{g} / \mathrm{L})$. 


\title{
Description of Landscape Features, Summary of Existing Hydrologic Data, and Identification of Data Gaps for the Osage Nation, Northeastern Oklahoma, 1890-2012
}

\author{
By William J. Andrews and S. Jerrod Smith
}

\section{Abstract}

The Osage Nation of northeastern Oklahoma, conterminous with Osage County, is characterized by gently rolling uplands and incised stream valleys that have downcut into underlying sedimentary rock units of Pennsylvanian through Permian age. Cattle ranching and petroleum and natural-gas extraction are the principal land uses in this rural area. Freshwater resources in the Osage Nation include water flowing in the Arkansas River and several smaller streams, water stored in several lakes, and groundwater contained in unconsolidated alluvial aquifers and bedrock aquifers. The Vamoosa-Ada aquifer is the primary source of fresh groundwater in this area. Fresh groundwater is underlain by saline groundwater in aquifers underlying the Osage Nation. Because of the potential for future population increases, demands for water from neighboring areas such as the Tulsa metropolitan area, and expansion of petroleum and natural-gas extraction on water resources of this area, the U.S. Geological Survey, in cooperation with the Osage Nation, summarized existing hydrologic data and identified data gaps to provide information for planning of future development of water resources in the Osage Nation.

Streamflows in the Osage Nation are substantially affected by precipitation. During the relatively wet periods from the 1970s to 2000, the annual streamflows in the Osage Nation increased by as much as a factor of 2 relative to preceding decades, with subsequent decreases in streamflow of as much as 50 percent being recorded during intermittent drier years of the early 2000s. This report summarizes hydrologic data from 3 surface-water sites and 91 wells distributed across the Osage Nation. Data collected at those sites indicate that surface water in the Osage Nation generally has sufficient dissolved oxygen for survival of both coldwater and warmwater aquatic biota. Total dissolved solids concentration exceeded the secondary drinking-water standard of 500 milligrams per liter $(\mathrm{mg} / \mathrm{L})$ in up to 75 percent of the surface-water samples, indicating limited availability of potable water at some sites. Some surface-water samples collected in the Osage Nation contained dissolved chloride concentrations exceeding the secondary drinking-water standard of $250 \mathrm{mg} / \mathrm{L}$, with greater chloride concentrations in selected basins appearing to be associated with greater densities of petroleum well locations. Several lakes sampled in the Osage Nation from 2011-12 contained sufficient chlorophyll- $a$ concentrations to be ranked as mesotrophic to eutrophic, indicating impairment by nutrients. Relatively large dissolved phosphorus concentrations in many surface-water samples, compared to water-quality standards, indicate that eutrophication can occur in local streams and lakes.

The amount of fresh groundwater stored in alluvial aquifers and the Vamoosa-Ada bedrock aquifer is adequate for domestic and other purposes in the Osage Nation at the current rate of usage. In areas where these aquifers are absent, groundwater must be pumped from minor bedrock aquifers that produce smaller volumes of water. About 30 and 60 percent of 32 and 54 water samples collected from the alluvial and Vamoosa-Ada aquifers, respectively, contained total dissolved solids concentrations larger than the secondary drinking-water standard of $500 \mathrm{mg} / \mathrm{L}$. Local factors, such as natural seepage of brines or leakage from petroleum and natural-gas extraction activities, may cause substantial variations in dissolved chloride concentration in groundwater in the Osage Nation. Total phosphorus concentrations measured in groundwater samples were similar to dissolved phosphorus concentrations measured in the base flow of several streams.

Total fresh surface-water withdrawals (use) and fresh groundwater withdrawals in the Osage Nation were estimated to have increased from 0.75 to 16.19 million gallons per day and from 0.13 to 2.39 million gallons per day, respectively, over the period from 1890 through 2010. Estimated salinegroundwater reinjection volumes at the heavily developed Burbank Oil Field in the Osage Nation from 1950 through 2012 were many times larger than the total amounts of freshwater withdrawn in this area, with estimated increases in saline-groundwater reinjection in the 2000 s probably being related to increased petroleum extraction. 
Estimates of freshwater resources in local streams, lakes, and freshwater aquifers and of net annual precipitation indicate that less than 1 percent of freshwater resources and net annual precipitation currently is being withdrawn annually in the Osage Nation. In addition to freshwater resources, the Osage Nation may be underlain by $45,000,000$ million gallons of brines, a small portion of which are withdrawn and reinjected during petroleum and natural-gas extraction. Ongoing development of desalinization technology may lead to the ability to expand use of these saline waters in the future.

Several additional studies could improve understanding of the hydrologic resources of the Osage Nation. Development of computer models (simulations) of groundwater and surfacewater flow for this area could enable testing of scenarios of localized and widespread effects of future climate variations and water-use changes on streamflows, lake-water levels, and groundwater levels in the Osage Nation. Installation of additional long-term streamflow and water-quality sampling stations, some with continuous water-quality monitors, could expand and improve understanding of surface-water quality. Periodic measurement of groundwater levels and sampling of water from a network of wells could provide better information about trends of groundwater quantity and quality with time. Measurement of water withdrawals at selected sites could enable more accurate estimates of water use. Lastly, better understanding of aquifer properties and spatial distribution of saline groundwater provided by geophysical surveys could improve understanding of fresh and saline groundwater resources underlying the Osage Nation.

\section{Introduction}

The Osage Nation of northeastern Oklahoma is coincident with the historical boundaries of the Osage Nation Reservation and Osage County. The Osage Nation encompasses an area of 2,297 square miles ( $\mathrm{mi}^{2}$ ) (fig. 1; U.S. Census Office, 1902) and is characterized by gently rolling uplands with locally sharp cuestas formed by resistant sandstone and limestone ledges (Abbott and Tortorelli, 2002). The Arkansas River flows along the western and southwestern boundaries of this area, with the Oklahoma/Kansas State line forming the northern boundary. The area is primarily rural, and much of it is used for cattle ranching and extraction of petroleum and natural gas. The term "Osage Nation" is used interchangeably in this report for the members of the Osage Nation, their tribal government, and the land area in which many tribal members reside.

The following synopsis of the history of the Osage Nation, in the context of current water-resource issues, is derived primarily from Osage Nation (2006). The Osage Nation originally lived in the Ohio Valley. Many of the Osage had migrated to the Osage River in western Missouri by 1673. Along with the Kiowa, Comanche, and Apache, the Osage dominated western Oklahoma and Kansas. The Osage Nation began making treaties with the United States in 1808, with the first secession of land holdings being in Missouri. Most of the Osage Nation had moved to land that would become Oklahoma soon after the passage of Lewis and Clark in the early 1800 s. By 1825 , the Osage Nation had ceded its traditional lands across Missouri, Arkansas, and Oklahoma to the United States. At that time, tribal members were moved onto a reservation in southeastern Kansas. Subsequent treaties and laws further reduced the lands of the Osage Nation. An act of Congress of July 15, 1870, provided that the remainder of the Osage Nation land in Kansas be sold and that the Osage Nation be relocated to Indian Territory (now Oklahoma), where they used the proceeds of those sales to buy their own reservation.

The Osage Nation subsisted on that reservation in the Indian Territory by cultivating small farms and later with cattle ranching in the productive tallgrass prairie area of the reservation. In 1894, large quantities of petroleum were discovered beneath the Osage Nation. Increasing petroleum extraction during the following 10 years prompted Congress to pass the Osage Allotment Act on June 28, 1906, which stated that all persons listed on tribal rolls prior to January 1, 1906, or born before July 1907 would be allocated a share of the reservation's subsurface natural resources. Drilling for petroleum on the Osage Reservation increased substantially after mineral leases were auctioned. Osage Nation shareholders soon became, in the words of many, the "richest people in the world." When royalties peaked in 1925, annual per capita earnings were $\$ 13,000$ for those on the allotment roll. Although the Osage Allotment Act protected the Osage Nation's petroleum interests, the surface land was sold freely. Between 1907 and 1923, thousands of acres of land were sold or leased to non-Indians.

Because of their reliance on cattle ranching and the potential for impairment of water quality by petroleum extraction, water rights are important to the Osage Nation. Water rights in tribal lands, such as those of the Osage Nation, are considered to be "Federal Reserved water rights," which supersede State and local water rights but have limits (Helton, 1998; J.J. Lawler, written commun., 1990). Under the Winters Doctrine, based on the United States Supreme Court decision in Winters v. United States of 1908 and subsequent case law, the intent of the Federal government when reserving land for an Indian reservation was to reserve an adequate supply of water to fulfill the purpose of the reservation (J.J. Lawler, written commun., 1990). For reservations such as the Osage Nation, the purpose of the reservation was for tribal members to live pastoral lives, which implies use of water not only for domestic purposes and livestock but also for irrigation (J.J. Lawler, written commun., 1990). Such reserved water rights are not limited by uses foreseen when a reservation was established and must be sufficient to make the land and resources productive for its residents, protections that are broader than those established to reserved water rights of other types of Federal reservations (Cohen, 1982). 


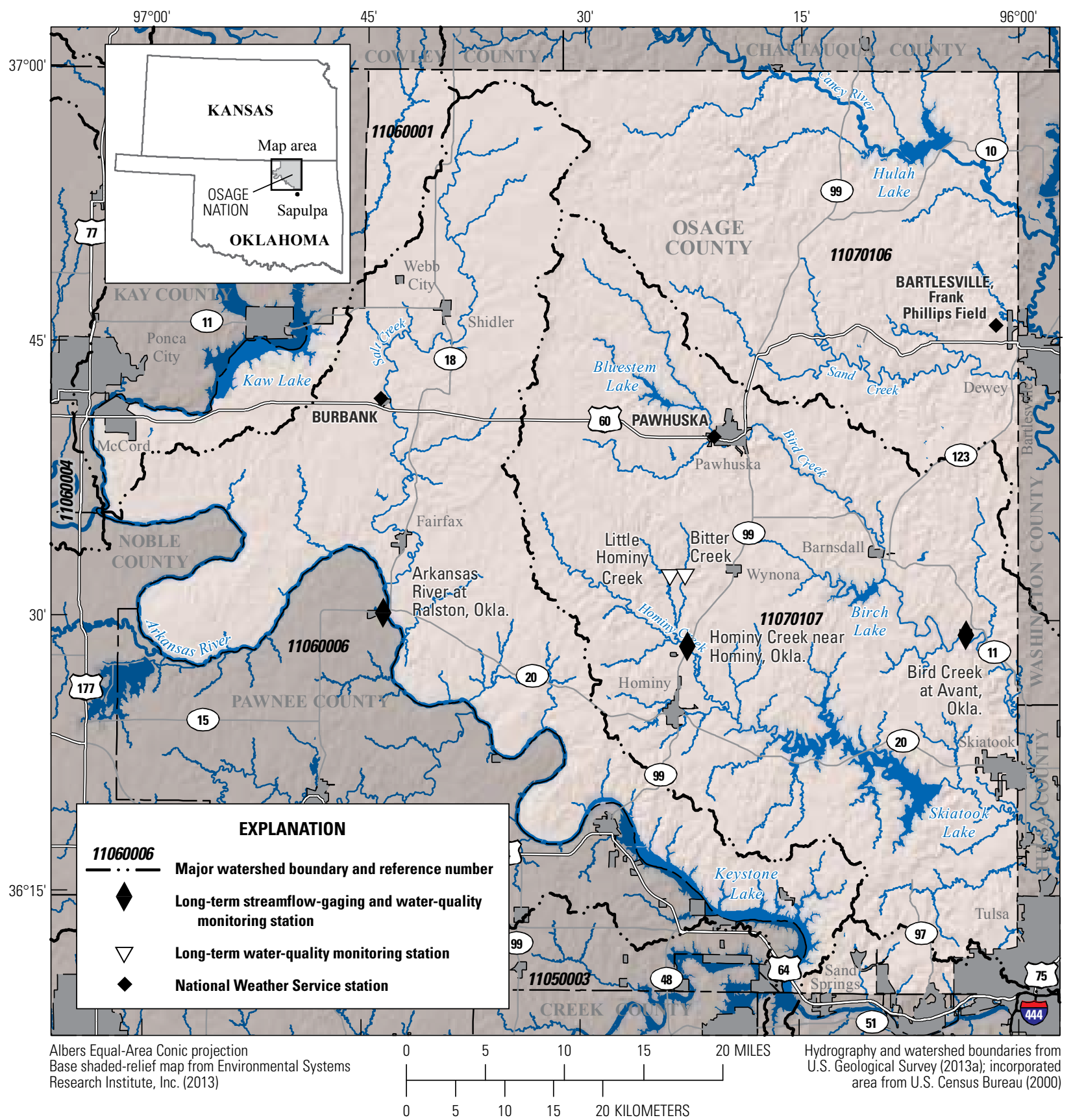

Figure 1. Locations of selected geographic features of the Osage Nation, northeastern Oklahoma. 
Because of the Supremacy Clause and establishment of tribal nations before the State of Oklahoma, tribes have water rights that supersede those of a State, but to effectively manage the dual system of water rights in Oklahoma, tribal water rights claims need to be quantified (Helton, 1998). The annual Federal reserved water rights of the Osage Nation have been estimated to be 13,887 acre feet (acre-ft), with the right to obtain additional in-stream flow of 427,160 acre-ft from the Arkansas River (about 20 percent of the average annual flow) (J.J. Lawler, written commun., 1990). Shields (1993) estimated a total freshwater resource of more than 30 million acre- $\mathrm{ft}$ in the Osage Nation and estimated that future water uses were unlikely to exceed 10 million acre-ft. Because of the potential for future population increases, demands for water from neighboring areas such as the Tulsa metropolitan area (fig. 1), and expansion of petroleum and natural-gas extraction affecting water resources, the U.S. Geological Survey, in cooperation with the Osage Nation, summarized existing hydrologic data and identified data gaps to provide information for planning of future development and water use in the Osage Nation.

\section{Purpose and Scope}

The purpose of this report is to describe (1) the climatic, geographic, and hydrogeologic setting; (2) the quality of water; (3) estimated water use (withdrawals) from 1890 through 2010; (4) water-resource estimates of the amounts of fresh surface water and fresh and saline groundwater available; and (5) gaps in existing hydrologic and related data in the Osage Nation. Summarizing existing data and identifying gaps in those data will enable better understanding of the fresh and saline water resources of that area.

\section{Methods of Analysis}

A variety of climatic, geographic, and hydrologic data were analyzed for this report. Sources of data and methods of analysis of those data are described in the following sections.

\section{Selection and Analysis of Climatic, Geographic, and Hydrogeologic Data}

Monthly precipitation and average air temperature data measured at National Weather Service (NWS) stations in the Osage Nation from 1970 through 2012 were downloaded from National Oceanic and Atmospheric Administration (2013). Data collected at three of those stations (Bartlesville, Frank Phillips Field; Burbank; and Pawhuska; fig. 1) from 1970 through 2012 are described in this report. Annual summaries of those data were not made for the years in which reported precipitation or temperature data were missing for one or more months.
Geographic data, including topographic, land-cover, soils, and other location data, were obtained from Abbott and others (1997), Abbott and Tortorelli (2002), Bourlier and others (1979), Boyd (2002), D'Lugosz and others (1986), Environmental Systems Research Institute, Inc. (2013), Fry and others (2011), Heran and others (2003), Natural Resources Conservation Service (2006, 2013), Oklahoma Water Resources Board (2013a), U.S. Census Bureau (2000), and U.S. Geological Survey (2012, 2013a, 2013b). Land-cover raster data showed the percentages of land cover for 30 - by 30 -meter cells. For computation of land-use percentages, the raster attributes were determined by using the ArcGIS Zonal Statistics as Table tool (Environmental Systems Research Institute, Inc., 2012).

Hydrogeologic data were obtained from previously published reports that included descriptions of geology and hydrogeology in the Osage Nation or other parts of Oklahoma with similar stratigraphy. Geologic reports reviewed included Beckwith (1928), Lee and others (1948), and Bingham and Bergman (1980). Hydrogeologic reports reviewed included Bingham and Bergman (1980), D'Lugosz and others (1986), Abbott (2000), DeHay and others (2004), and Christenson and others (2011).

\section{Selection and Analysis of Streamflow and Surface-Water-Quality Data}

Streamflow and surface-water-quality data were obtained from the National Water Information System (NWIS) of the U.S. Geological Survey (USGS) (U.S. Geological Survey 2013b), the Storage and Retrieval (STORET) database of the U.S. Environmental Protection Agency (EPA) (U.S. Environmental Protection Agency, 2013a), and records of the Oklahoma Water Resources Board (OWRB, Oklahoma Water Resources Board, 2013b). Streamflow data collected from three long-term streamflow-gaging stations operated by the USGS in the Osage Nation (Hominy Creek near Hominy, Okla.; Bird Creek at Avant, Okla.; and Arkansas River at Ralston, Okla.) were graphed, with trends in streamflow through time shown by using locally estimated scatterplot smoothing (LOESS) curves. LOESS curves are nonparametric regressions that reduce the influence of outlying data used to identify a trend line for a range of data (Cleveland and Devlin, 1988; Helsel and Hirsch, 2002).

USGS streamflow and surface-water-quality data were collected by using consistent methods over time that were designed to most closely represent streamflow and the quality of water across the extent of stream channels (Rantz and others, 1982; U.S. Geological Survey, 2006). USGS-operated streamflow-gaging stations and locations of those stations in the Osage Nation are listed on table 1. Methods used to collect data uploaded to the STORET database by other agencies are unknown.

Selection and analysis of surface-water-quality data for this report were limited to the dissolved water-quality 
Table 1. Names and locations of selected streamflow-gaging stations in the Osage Nation, northeastern Oklahoma, 1982 through 2013. [mm, month; dd, day; yyyy, year; N, north; W, west]

\begin{tabular}{|c|c|c|c|c|}
\hline $\begin{array}{c}\text { Streamflow-gaging } \\
\text { station name }\end{array}$ & $\begin{array}{l}\text { Streamflow-gaging } \\
\text { station number }\end{array}$ & $\begin{array}{l}\text { Latitude and longitude } \\
\text { (decimal degrees) }\end{array}$ & $\begin{array}{l}\text { Drainage area } \\
\text { (square miles) }\end{array}$ & $\begin{array}{l}\text { Period of record } \\
\text { (mm/dd/yyyy) }\end{array}$ \\
\hline Hominy Creek near Hominy, Okla. & 07176950 & $\begin{array}{l}36.4736 \mathrm{~N} \\
96.3786 \mathrm{~W}\end{array}$ & 115 & 09/30/2003-09/20/2007 \\
\hline Bird Creek at Avant, Okla. & 07176500 & $\begin{array}{l}36.4850 \mathrm{~N} \\
96.0600 \mathrm{~W}\end{array}$ & 369 & $08 / 30 / 1945-07 / 15 / 2013$ \\
\hline Arkansas River at Ralston, Okla. & 07152500 & $\begin{array}{l}36.5042 \mathrm{~N} \\
96.7281 \mathrm{~W}\end{array}$ & 46,631 & $10 / 01 / 1925-07 / 15 / 2013$ \\
\hline
\end{tabular}

constituents oxygen, total solids, chloride, and phosphorus. For the last three of these parameters, "dissolved" means that the concentrations of the water-quality constituents were analyzed after the water samples had been filtered in the field through filters with effective pore diameter of 0.45 micrometers. Dissolved oxygen concentration provides an indication of the aerobic breakdown of organic compounds that grow in or are discharged to streams and indicates the suitability of streams as habitat for aerobic aquatic organisms such as fish, amphibians, mollusks, and insects. Total dissolved solids concentration provides an indication of the mineral content of water that can limit the use of water for drinking and other purposes, as described in EPA secondary drinking-water standards (U.S. Environmental Protection Agency, 2013b). Dissolved chloride concentration is described in this report because of potential mixing of freshwater with brines from underlying saline-water aquifers and brines brought to the land surface in the course of extensive petroleum and natural-gas extraction in the Osage Nation (Bourlier and others, 1969; Abbott and Tortorelli, 2002; Kharaka and Otton, 2003; U.S. Geological Survey, 2013e). Dissolved phosphorus, also described in this report, has been associated with eutrophication of streams in northeastern Oklahoma, as described in Andrews and others (2009).

Surface-water-quality data were summarized only for sites at which 10 or more samples were collected for analysis of one or more of these constituents (dissolved oxygen, total dissolved solids, and dissolved chloride and phosphorus), with streamflow being measured at the time of surface-water sample collection (a total of 250 samples collected at three sites by multiple agencies). To represent recent surface-water quality in the Osage Nation, only surface-water-quality data collected from 1999 through 2012 are summarized in this report. Because of those constraints, surface-water-quality data collected by the USGS at 1 site, the Osage Nation at 3 sites, the Oklahoma Conservation Commission (OCC) at 1 site, and the OWRB at 1 site are described in this report (table 2).

Distributions of water-quality-constituent concentrations are shown graphically with boxplot graphs in this report. Groups of data values were compared by using the two-sided Wilcoxon rank-sum test (Wilcoxon, 1945), with pairs of data groups having $p$-values of this test less than or equal to
0.05 being deemed to represent significantly different data distributions. Relations of dissolved chloride and dissolved phosphorus to streamflow are shown in x:y graphs. Statistical tests used for this report and graphs shown in this report were made with TIBCO Spotfire S+ software (TIBCO Software Incorporated, 2008).

\section{Selection and Analysis of Groundwater-Quality Data}

Groundwater-quality data collected in the Osage Nation were obtained from the USGS NWIS database (U.S. Geological Survey, 2013a). To evaluate groundwater-quality data from aquifers and relations of groundwater quality to depth below land surface, groundwater-quality data from wells completed in known aquifers with known depths were evaluated for this report. The STORET database did not contain groundwater-quality data associated with wells of known depths and aquifers for this area.

Dissolved groundwater-quality parameters described in this report include oxygen, total dissolved solids, and dissolved chloride. Because dissolved phosphorus concentration data were not available for groundwater samples collected in this area, total (unfiltered) phosphorus concentrations are described for groundwater samples collected by the USGS in this report. Groundwater-quality data collected by the USGS from alluvial aquifers along the Arkansas River at temporary sampling wells (Mashburn and others, 2003) are not summarized in this report because those data did not come from permanent wells that can be resampled, and the only parameter relevant to this report that was measured in samples collected from those wells was dissolved oxygen determined colorimetrically, rather than by calibrated meter.

For sampled wells of known depths that were lacking aquifer designations in the NWIS database, aquifers were assigned on the basis of location and well depth. Aquifer and geologic maps in Bingham and Bergman (1980) and Johnson (1983) were compared with well locations to determine if the land on which wells were located was underlain by alluvial aquifers, the Vamoosa-Ada aquifer, or minor bedrock aquifers. 
Table 2. Names and locations of selected surface-water-quality sites sampled in the Osage Nation, northeastern Oklahoma, 1999 through 2012.

[mm, month; dd, day; yyyy, year; USGS, U.S. Geological Survey; N, north; W, west; OCC, Oklahoma Conservation Commission; OWRB, Oklahoma Water Resources Board]

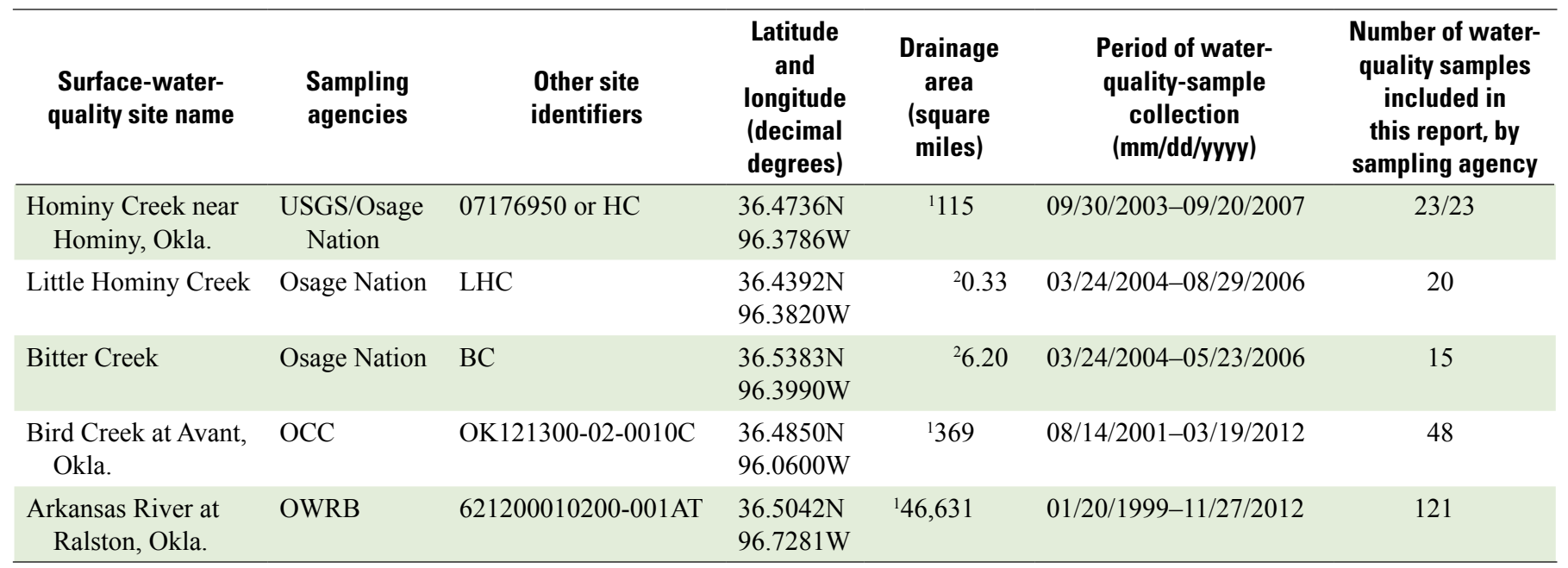

${ }^{1}$ From U.S. Geological Survey (2013a).

${ }^{2}$ Estimated from agency-supplied latitude and longitude and U.S. Geological Survey (2013b).

Minor bedrock aquifers underlying the western part of the Osage Nation are composed of layers of shales, limestones, and sandstones of the Oscar Group and the Vanoss Group, both of Pennsylvanian age (Bingham and Bergman, 1980). In areas likely to be underlain by alluvial aquifers, wells less than 100 feet (ft) deep were designated as being completed in alluvial aquifers, with deeper wells in these areas being assigned to one of two designations of bedrock aquifersVamoosa-Ada or minor bedrock.

Groundwater-quality samples were collected by using standard USGS field methods (U.S. Geological Survey, 2006) and were analyzed in USGS laboratories. Total dissolved solids data were determined either by evaporation of water samples at 180 degrees Celsius or by summing measured concentrations of dissolved constituents. Some of the total phosphorus data for groundwater samples were left-censored, meaning that they were less than the laboratory reporting level of 0.002 milligrams per liter $(\mathrm{mg} / \mathrm{L})$. The adjusted maximum likelihood estimation method (Cohn, 1988) was used in a USGS-customized version of the TIBCO Spotfire S+ software (TIBCO Software Incorporated, 2008) to estimate the distribution of those censored data below that reporting limit for compilation of boxplots.

\section{Selection and Analysis of Water-Use Data}

The USGS has been compiling water-use data for Oklahoma every 5 years by county since 1950 (U.S. Geological Survey, 2013c). Water-use (water-withdrawal) data compiled by the USGS are categorized by source type (surface water or groundwater) for a limited number of purposes (public supply, domestic self-supplied [groundwater only], industrial self-supplied, irrigation, livestock, aquaculture, mining [including water used for petroleum and natural-gas drilling and extraction], and thermoelectric [water used for electric-power generation]). Water use by public suppliers includes withdrawals of freshwater made by municipalities and rural water districts to provide water for domestic, commercial, and industrial uses. Domestic self-supplied water use generally consists of freshwater withdrawals by domestic ("private") wells in areas outside the service areas of public water suppliers.

Water-use data compiled in 2005 by the USGS for Oklahoma counties for those categories were summarized in Tortorelli (2009). Water-use data for Osage County from 1985 through 2000 were obtained from the Aggregate Water Use Data System (AWUDS) database maintained by the USGS, except for livestock (U.S. Geological Survey, 2013d). Historical estimates for livestock water use in the AWUDS database and other sources used different coefficients from 1985 to 2010, used different means of aggregating numbers of livestock, and estimated no livestock water use in 1985 for this area, so more consistent methods of estimating livestock water use were used for this report. USGS reports describing water use on a statewide basis at 5-year intervals from 1955 through 1990 were sources of water-use data for that period (MacKichan, 1957; MacKichan and Kammerer, 1961; Murray, 1968; Murray and Reeves, 1972, 1977; Solley and others, 1983, 1988, 1993). Water-use quantities from before 1950 were estimated from human-population estimates for the 
county compiled every 10 years and interpolated for each intervening 5-year period (Bureau of the Census, 2002) and from reports of livestock numbers and crop production (U.S. Census Office, 1895, 1902; Bureau of the Census, 1927, 1936, 1942, 1946, 1952, 1956, 1961, 1967, 1972, 1977, 1982, 1984, 1989, 1994, 1999, 2004, 2009; National Agricultural Statistics Service, 2011).

Typical domestic water use in the United States changed substantially during the 20th century with the advent and adoption of indoor plumbing, more frequent bathing and clothes washing, and increased lawn irrigation (World Water Council, 2014). Because of those changes, per capita domestic water consumption was estimated to have increased from 15 gallons per day (gal/d) in 1890-1915 (a number derived from recent per capita water use in third world countries reported by Watkins and others, 2006) to $35 \mathrm{gal} / \mathrm{d}$ from 1920 through 1935, $60 \mathrm{gal} / \mathrm{d}$ from 1940 through 1965, and 85 gal/d from 1970 through 2010 (Tortorelli, 2009). Estimates of domestic self-supplied water withdrawals were based on those per capita water-use numbers multiplied by the numbers of residents not served by public water suppliers and were made by using the assumption that domestic self-supplied water users withdrew their water from wells rather than from surface-water sources. Numbers of residents served by public water suppliers were extrapolated by linear regression by estimating that zero residents were served by public water suppliers in the late 1890 s to the numbers reported to be served by public water suppliers in the 1980s through 2010. Quantities of water withdrawn by public suppliers for domestic purposes were not determined for this report; rather, the total amounts of surface water and groundwater withdrawn for public supply for domestic, commercial, industrial, and other purposes were taken from existing estimates of public water supply withdrawals from 1985 through 2010 or were estimated by linear interpolation from 1985 withdrawal numbers to assumed withdrawals of zero by public water suppliers in the 1890s.

Self-supplied freshwater withdrawals for industrial uses were not quantified for the Osage Nation prior to 1985. Rather than estimating freshwater withdrawals for industrial uses in the Osage Nation from 1950 through 1980 from statewide data (Tortorelli, 2009), estimates of industrial self-supplied water withdrawals from 1890 through 1980 were based on linear regressions based on the human population of the area back to 1890 , with the assumption that there was zero industrial water use in the late 1890s in this area and that industrial production and water use for that purpose were proportional to population of this area.

Water withdrawals for agricultural purposes was estimated for irrigation, livestock, and aquaculture for this report. Water-use data for irrigation from 1985 through 2010 were obtained from the USGS AWUDS database (U.S. Geological Survey, 2013d). To estimate earlier water withdrawals for agriculture, several agricultural censuses were used, including censuses described in Bureau of the Census (1927, 1936, 1942, 1946, 1952, 1956, 1961, 1967, 1972,
1977, 1984, and 1989). Agricultural census reports indicated that no irrigation was used in the Osage Nation through 1950. Water withdrawals for irrigation from 1955 through 1980 were estimated by linear regression from zero acres reported in 1950 through the reported numbers in subsequent agricultural censuses and in the AWUDS database from 1985 through 2010 (U.S. Geological Survey, 2013d). Withdrawals of water for livestock were estimated from agricultural census counts of numbers of livestock and per-head coefficients of water use of $20 \mathrm{gal} / \mathrm{d}$ for dairy cattle; $10 \mathrm{gal} / \mathrm{d}$ for horses, mules, and beef cattle; $3 \mathrm{gal} / \mathrm{d}$ for hogs; $2 \mathrm{gal} / \mathrm{d}$ for sheep and goats; and $0.04 \mathrm{gal} / \mathrm{d}$ for chickens (MacKichan and Kammerer, 1961). Agricultural census data also were used to estimate livestock water use for the period 1985-2010 (Bureau of the Census, 1989, 1994, 1999, 2004, and 2009). For the 1890 Census of Agriculture (U.S. Census Office, 1895), only six Oklahoma counties were surveyed, so estimated water-use numbers for livestock were based on the percentage change of estimated human population from 1890 to 1895 , which assumes that the number of livestock were proportional to the number of human residents over that period. In the 1900 Census of Agriculture (U.S. Census Office, 1902) monetary values of chickens rather than numbers of chickens were used. Because of the negligible amount of water use by chickens in the Osage Nation in later periods (typically less than 0.01 million gallons per day $[\mathrm{Mgal} / \mathrm{d}])$, numbers of chickens and their corresponding water use were assumed to be zero in the Osage Nation for the period 1890-1905. As agricultural censuses were not conducted in 1905 and 1915, estimates of livestock numbers and water use in those years were made from the means of livestock numbers and water use in preceding and subsequent agricultural censuses. Because county livestock numbers were not recorded from 1890 to 1920 , statewide numbers of livestock reported for 1925-1950 (Bureau of the Census, 1927, 1936, 1942, 1946, 1952) were compared to Osage County livestock numbers by linear regression to derive estimates of county livestock numbers for 1890-1920, assuming that livestock numbers in the Osage Nation were proportional to statewide livestock numbers. Agricultural censuses do not indicate sources of water used for livestock, so estimates of surface water and groundwater used for livestock were made on the basis of a ratio of 9 to 1 of the surfacewater to groundwater use for livestock in the Osage Nation in recent decades (R. Tortorelli, U.S. Geological Survey, written commun., 2012). Estimates of water withdrawals for aquaculture in the Osage Nation were reported to be zero until 2010.

For this report and the USGS AWUDS database, water withdrawn for mining includes withdrawals used for sandand-gravel, coal, and hard-rock mining and onsite processing and extraction of petroleum and natural gas. No freshwater withdrawals for mining were estimated to have occurred in the Osage Nation from 1985 through 2010 (U.S. Geological Survey, 2013d). Freshwater withdrawals for mining also were assumed to have been negligible for the period from 1890 to 1980. Petroleum and natural-gas wells typically withdraw 
substantial quantities of saline groundwater commonly referred to as "produced water" from deep strata underlying freshwater aquifers in the Osage Nation (U.S. Geological Survey, 2013d). That saline water typically is reinjected into surrounding wells in the process of water flooding, which is a means of driving residual petroleum to a central gathering well, or that water is reinjected into deep disposal wells (Abbott and Tortorelli, 2002; U.S. Oil and Gas Corporation, 2008; U.S. Geological Survey, 2013d). In some cases, saline waters produced from petroleum and natural-gas wells have leaked or been discarded into surface water in the Osage Nation and surrounding areas, increasing salinity of streams and causing salt scars of devegetated, eroded gullies near streams (Abbott and Tortorelli, 2002). For this report, salinegroundwater withdrawals (as measured by reinjection for water flooding) were estimated only for the Burbank Oil Field on the basis of compilation of data from the Calumet Oil Company, Chaparral Energy, Inc., Phillips Petroleum Company, petroleum information secondary recovery books, and the EPA (Erwin Pino, DeLon Flinchum, and Matt Stover, Chaparral Energy, Inc., written commun., 2013). Similar water-use data were not available for other petroleum and natural-gas extraction fields in the Osage Nation at the time that this report was written.

On a statewide basis, substantial quantities of water are withdrawn for thermoelectric purposes, the generation of electrical power by converting water to steam and cooling plant components (Tortorelli, 2009). Because no known electrical powerplants have operated in the Osage Nation for the past several decades (Tortorelli, 2009), no water was estimated to be withdrawn for this purpose in this area from 1890 to 2010.

\section{Quality Assurance}

Quality assurance, the process by which the accuracy and precision of water-quality data are determined, is done by comparison of analyses of quality-control water samples with analyses of field water samples. In this report, reproducibility and natural variability of water-quality data are represented by relative percent differences (RPDs) in data between fieldreplicate and field water samples. Effectiveness of equipment cleaning and sample-collection methods at preventing watersample contamination is evaluated by comparison of data from analyses of field-blank water samples and from analyses of field water samples. Field-blank water samples described in this report were prepared with inorganic-grade blank water prepared and tested by the USGS National Water Quality Laboratory in Lakewood, Colorado.

Quality assurance is documented in this report through thorough descriptions of methods and protocols in the preceding paragraphs and descriptions of analyses of blank and replicate water-quality samples. Blank water-quality samples indicate the efficacy of cleaning of field equipment and of sample analyses protocols and procedures. Replicate water-quality samples, if collected sequentially in time, indicate short-term water-quality variability at a particular site and fluctuations in the accuracy of laboratory and field measurements of water-quality parameter values. Splitduplicate samples, which are derived from the same wellmixed water samples, document the accuracy or variability of field and laboratory measurements of water-quality parameters. RPD is a measure of the difference between a constituent concentration in a pair of field and field-replicate water samples, with smaller RPD values indicating larger similarity of data in sample pairs. RPD is calculated as follows:

$$
\mathrm{RPD}=(|a-b| /((a+b) / 2)) * 100,
$$

where

$a \quad$ is the constituent concentration of the field sample, and

$b \quad$ is the constituent concentration of the fieldreplicate sample.

\section{Surface-Water-Quality Data}

The only accessible quality-control data associated with surface-water samples collected in the Osage Nation during the study period were two samples collected by the USGS in 2004 and 2005 (table 3). Because quality-control data for the surface-water-quality data collected by the Osage Nation, OCC, and OWRB in the Osage Nation were not in the STORET database, the quality of those data could not be quantified for this report.

RPDs of field surface-water samples and field replicate surface-water samples were less than 10 percent (table 3). The blank water-quality sample collected in the Osage Nation in association with field surface-water samples did not contain detectable concentrations of total dissolved solids or dissolved chloride (table 4), indicating a small likelihood of contamination of field samples by those constituents associated with sampling equipment and other environmental factors in the time period in which the blank water-quality sample was collected. Collection by the USGS of 2 fieldreplicate surface-water samples and 1 blank water-quality sample with 23 surface-water samples represents frequencies of collection of about 10 and 5 percent, respectively.

\section{Groundwater-Quality Data}

Field-replicate groundwater samples were collected from 2 of the 91 wells sampled by the USGS in the Osage Nation from 1972 through 1997. Of those two samples, the largest RPD (40 percent) between a field groundwater sample and a field-replicate groundwater sample was determined for total phosphorus concentration in a sample collected in December 1997 from a well completed in an alluvial aquifer (table 5). The difference in total phosphorus concentration between those two samples was relatively small, with a concentration of $0.003 \mathrm{mg} / \mathrm{L}$ being measured in the field sample and a 
Table 3. Relative percent differences of surface-water-quality data between field surface-water samples and field-replicate surface-water samples collected by the U.S. Geological Survey in the Osage Nation, northeastern Oklahoma, 2004 through 2005.

\begin{tabular}{cccc}
\hline $\begin{array}{c}\text { Surface-water } \\
\text { sampling site } \\
\text { name }\end{array}$ & Date & $\begin{array}{c}\text { Water-quality } \\
\text { constituent }\end{array}$ & $\begin{array}{c}\text { Relative } \\
\text { percent } \\
\text { difference }\end{array}$ \\
\hline Hominy Creek & $\begin{array}{c}\text { August 18, } \\
\text { near Hominy, }\end{array}$ & Dissolved oxygen & 5.92 \\
Okla. & June 27, & Dissolved chloride & 0.75 \\
& 2005 & Dissolved chloride & 0.00 \\
\hline
\end{tabular}

Table 4. Selected constituent concentrations measured in a blank water-quality sample associated with surface-water samples collected by the U.S. Geological Survey in the Osage Nation, northeastern Oklahoma, 2005.

$[<$, less than]

\begin{tabular}{lccc}
\hline $\begin{array}{c}\text { Surface-water } \\
\text { sampling site } \\
\text { name }\end{array}$ & Date & $\begin{array}{c}\text { Water-quality } \\
\text { constituent }\end{array}$ & $\begin{array}{c}\text { Concentration } \\
\text { (milligrams } \\
\text { per liter) }\end{array}$ \\
\hline $\begin{array}{c}\text { Hominy Creek } \\
\text { near Hominy, }\end{array}$ & $\begin{array}{c}\text { March 29, } 29 \\
\text { Okla. }\end{array}$ & $\begin{array}{c}\text { Total dissolved } \\
\text { solids }\end{array}$ & $<10$ \\
Dissolved chloride & $<0.02$ \\
\hline
\end{tabular}

Table 5. Relative percent differences of groundwater-quality data between field groundwater samples and field-replicate groundwater samples collected by the U.S. Geological Survey in the Osage Nation, northeastern Oklahoma, 1997.

\begin{tabular}{|c|c|c|c|c|}
\hline $\begin{array}{l}\text { Groundwater } \\
\text { site number }\end{array}$ & Aquifer & Date & $\begin{array}{c}\text { Water- } \\
\text { quality } \\
\text { constituent }\end{array}$ & $\begin{array}{c}\text { Relative } \\
\text { percent } \\
\text { differ- } \\
\text { ence }\end{array}$ \\
\hline \multirow{2}{*}{363025096230901} & \multirow{2}{*}{$\begin{array}{l}\text { Alluvial } \\
\text { and } \\
\text { terrace }\end{array}$} & \multirow{2}{*}{$\begin{array}{c}\text { November } \\
5,1997\end{array}$} & $\begin{array}{r}\text { Dissolved } \\
\text { chloride }\end{array}$ & 0.00 \\
\hline & & & $\begin{array}{l}\text { Total } \\
\text { phosphorus }\end{array}$ & 0.00 \\
\hline \multirow{2}{*}{364014096114801} & \multirow{2}{*}{$\begin{array}{l}\text { Alluvial } \\
\text { and } \\
\text { terrace }\end{array}$} & \multirow{2}{*}{$\begin{array}{r}\text { December } \\
17,1997\end{array}$} & $\begin{array}{r}\text { Dissolved } \\
\text { chloride }\end{array}$ & 1.04 \\
\hline & & & $\begin{array}{l}\text { Total } \\
\text { phosphorus }\end{array}$ & 40.0 \\
\hline
\end{tabular}

concentration of less than $0.002 \mathrm{mg} / \mathrm{L}$ being measured in the field-replicate sample (with the RPD being calculated from the detected concentration in the first sample and the reporting limit in the second sample). No detectable dissolved chloride concentrations (with a reporting limit of $0.10 \mathrm{mg} / \mathrm{L}$ ) were measured in blank water-quality samples associated with groundwater samples collected by the USGS in 1997, but small concentrations of total phosphorus were detected in those samples (table 6). Those total phosphorus concentrations of 0.005 and $0.003 \mathrm{mg} / \mathrm{L}$ were near the reporting limit of $0.002 \mathrm{mg} / \mathrm{L}$, indicating negligible contamination of field water samples from sampling equipment or other environmental factors at the time of collection of those samples.

Collection by the USGS of 2 field-replicate water samples and 2 blank water-quality samples in 1997 in association with collection of 91 groundwater samples collected from 1972 to 1997 represents frequencies of collection of about 2 percent. Because quality-control data for the surface-water-quality data collected by the Osage Nation, OCC, and OWRB in the Osage Nation were not in the STORET database, the quality of those data could not be quantified for this report.

\section{Description of Landscape Features of the Study Area}

The Osage Nation is sparsely populated, with a population density of about 21 residents per square mile (U.S. Census Bureau, 2013). The primary economic activities in this area are cattle ranching and extraction of petroleum and natural gas. Population density, land uses, and other features such as climate, physiography and vegetation, land cover, soils, geology, and hydrogeology can affect the quantity, quality, and distribution of water resources in the Osage Nation.

Table 6. Selected constituent concentrations measured in blank water-quality samples associated with groundwater samples collected by the U.S. Geological Survey in the Osage Nation, northeastern Oklahoma, 1997.

$[<$, less than $]$

\begin{tabular}{lllc}
\hline $\begin{array}{c}\text { Groundwater site } \\
\text { number }\end{array}$ & Date & $\begin{array}{c}\text { Water-quality } \\
\text { constituent }\end{array}$ & $\begin{array}{c}\text { Concentration } \\
\text { (milligrams } \\
\text { per liter) }\end{array}$ \\
\hline 364022097030001 & $\begin{array}{c}\text { October 20, } \\
1997\end{array}$ & $\begin{array}{c}\text { Dissolved chlo- } \\
\text { ride } \\
\text { Total phosphorus }\end{array}$ & $<0.1$ \\
\hline 364600096125101 & $\begin{array}{c}\text { November } \\
17,1997\end{array}$ & $\begin{array}{c}\text { Dissolved chlo- } \\
\text { ride }\end{array}$ & $<0.1$ \\
\hline & Total phosphorus & 0.003 \\
\hline
\end{tabular}




\section{Climate}

The climate of the Osage Nation is temperate, annually receiving about 36 inches of precipitation in the west and northeast to 45 inches in the southeast (Oklahoma Climatological Survey, 2013). The wettest months typically are May and September (Oklahoma Climatological Survey, 2013). Snowfall ranges from 1 to more than 10 inches per year (Oklahoma Climatological Survey, 2013). Annual precipitation at three long-term NWS stations in the Osage Nation increased or decreased slightly from the late 1970s through the early 1980 s, increased from the mid-1980s through the early 1990s, and then increased or decreased slightly from the mid-1990s through the 2010s (fig. 2).
Air temperatures in the Osage Nation average about 59 degrees Fahrenheit $\left({ }^{\circ} \mathrm{F}\right)$ annually, with average daytime high temperatures of about $93^{\circ} \mathrm{F}$ being measured in July and average low temperatures of about $23^{\circ} \mathrm{F}$ being measured in January (Oklahoma Climatological Survey, 2013). Winds in this area are dominantly from the south, averaging about 9 miles per hour. Thunderstorms occur on about 50 days annually, predominantly in the spring and summer (Oklahoma Climatological Survey, 2013). From 1950 through 2003, 66 tornadoes were recorded in Osage County (Oklahoma Climatological Survey, 2013). Annual mean air temperature generally increased from 1970 to 2007 by about $1^{\circ} \mathrm{F}$ at the NWS field station at Pawhuska, Okla., with a negligible increase being measured at the NWS

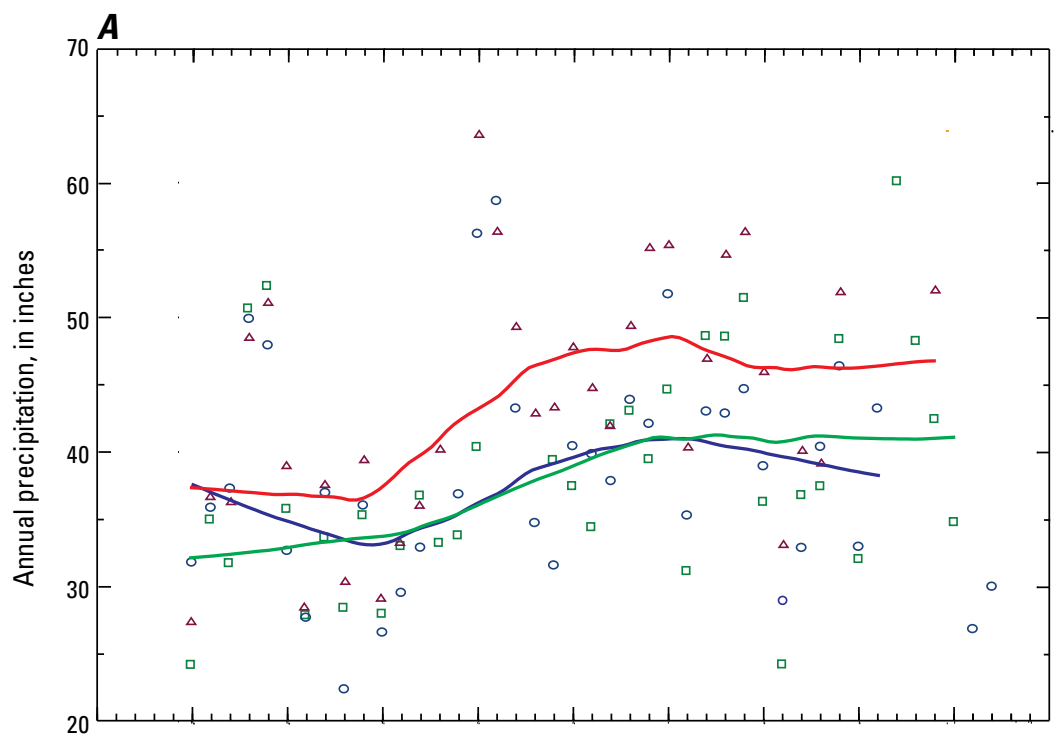

EXPLANATION

National Weather Service station-Color-coordinated lines indicate locally estimated scatterplot smoothing lines (Cleveland and Devlin, 1988)

Bartlesville, Frank Phillips Field

Pawhuska

Burbank

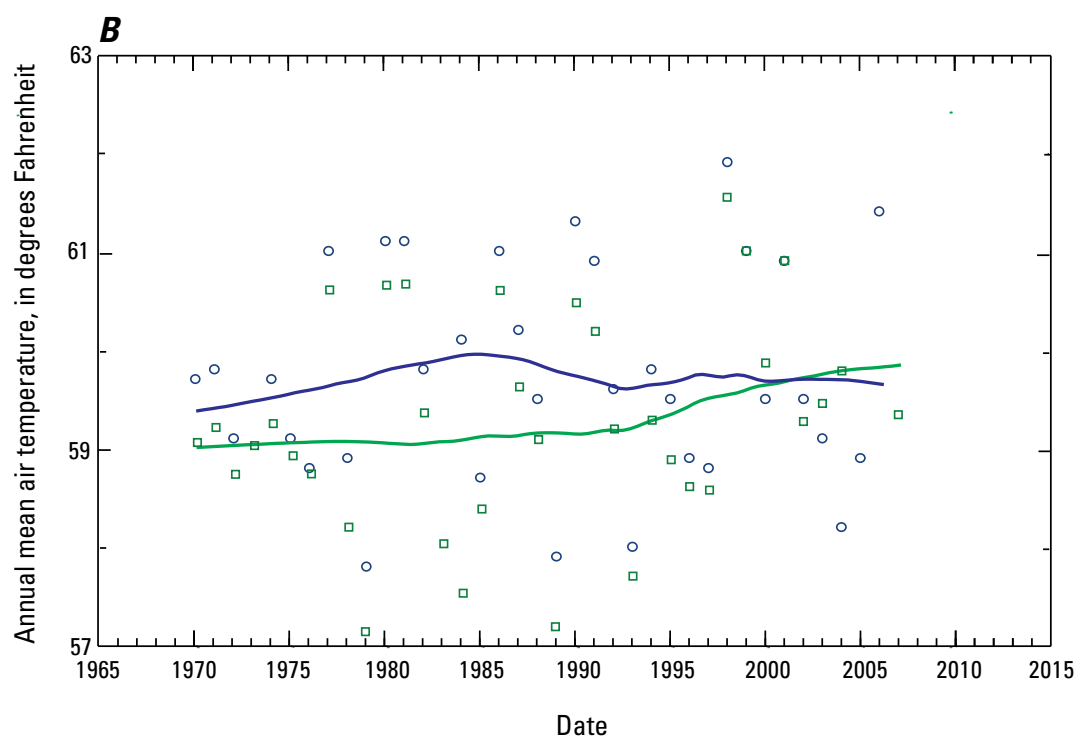

Figure 2. Climate data from three selected weather stations in the Osage Nation, northeastern Oklahoma, 1970 through 2012. A, Annual precipitation. $B$, Annual mean air temperature. 
station at Frank Phillips Field in Bartlesville, Okla. (fig. 2). Insufficient temperature data were collected at the NWS field station at Burbank, Okla., to graph annual mean air temperatures (fig. 2).

\section{Physiography and Vegetation}

The Osage Nation is in the Osage Plains section of the Central Lowland physiographic province (Fenneman and Johnson, 1946), a section characterized by a low-relief plain punctuated by east-facing escarpments formed by cuestas, with mixed-grass prairie in the west transitioning to mixed tallgrass savannahs and woodlands to the east. The eastern and southeastern parts of this area are in the cross timbers ecoregion (Omernik, 1987), an area characterized by open oak (Quercus spp.) and hickory (Carya spp.) woodlands with scattered grassy savannahs developed on sandy soils (Abbott and Tortorelli, 2002). The western part of the Osage Nation is mostly open savannah (Abbott and Tortorelli, 2002). The Osage Nation is drained by the Caney River in the northeast, Bird Creek in the southeast, and Salt Creek in the west and is bounded on the west and southwest for 123 miles by the Arkansas River (fig. 1).

\section{Land Cover}

More than half of the land cover in the Osage Nation is classified as grassland or scrub (fig. 3), much of which is used as pasture for beef cattle in the western half of the area. The eastern half of the Osage Nation tends to be more forested with oaks and other deciduous tree species, particularly along stream and river valleys (fig. 3 ). Lowland areas near the Arkansas River and smaller streams in the Osage Nation are naturally wetter or more easily irrigated from alluvial aquifers, and are used for pasture, or for growing hay or other cultivated crops (fig. 3). Land cover in approximately 5 percent of the Osage Nation is developed or barren (fig. 3), with developed areas consisting of small cities and towns and the northwest edge of the Tulsa metropolitan area near the southeast corner of the Osage Nation. Slightly more than 4 percent of the Osage Nation is covered by water or wetlands, primarily by the Arkansas River and impounded lakes, including Kaw, Hulah, Bluestem, Birch, Keystone, and Skiatook Lakes (fig. 3).

\section{Soils}

Soils in the Osage Nation are mixed, thermic, ustic to udic mollisols and alfisols (Shields, 1993), meaning that they are dry to wet prairie and forest soils with large organic-matter content formed under high temperatures. According to Natural Resources Conservation Service (2013) and Bourlier and others (1979), there are three major types of soils in the Osage Nation: (1) deep loamy and sandy soils on wooded flood plains, (2) deep to shallow loamy soils on prairie uplands, and (3) deep to shallow loamy and sandy soils on wooded uplands (fig. 4). The soil associations composing those three general categories generally are sandy to loamy, deep to moderately deep, well-drained to somewhat poorly drained, nearly level to steeply sloping soils underlying open prairies in the western third of the Osage Nation, and underlying stream valleys and uplands in the eastern two-thirds of the area (Bourlier and others, 1979). Such soils are likely to be highly permeable in most areas, facilitating recharge of precipitation to aquifers below the land surface.

The western part of the Osage Nation underlain by prairie soils (mollisols) was part of the band of native tallgrass prairie that once spanned from eastern Texas northward into southern Canada, and eastward through Iowa and the northern half of Illinois (Madsen and Oberle, 1993). The tallgrass prairie was a very diverse grassland ecosystem dominated by grasses and forbs growing between 5 and $10 \mathrm{ft}$ tall, with encroachment of woody plants being controlled by natural fire cycles and grazing by American bison (Bison bison) (Cushman, 2004). Such prairies are associated with mollisol soils, which generally are very thick, with thick, organic-rich A (top) horizons (Natural Resources Conservation Service, 2014).

\section{Geology and Hydrogeology}

The Osage Nation is underlain by three major aquifers: alluvial and terrace (referred to in the remainder of this report as "alluvial"), consisting of unconsolidated sands, silts, clays, and gravels deposited along streams and rivers in the Quaternary Period; the Vamoosa-Ada aquifer consisting of a sequence of sandstones, siltstones, shales, conglomerates, and limestones deposited in marine environments in the Pennsylvanian Period; and minor bedrock aquifers deposited during the Pennsylvanian Period in the eastern part of the Osage Nation and during the Pennsylvanian through Permian Periods in the western part of the Osage Nation where the Vamoosa-Ada aquifer is absent (fig. 5). The Pennsylvanian System strata consist of alternating layers of sandstones, shales, and limestones stacked in a westward-dipping monocline (Shields, 1993; table 7). The Pennsylvanian System strata are underlain by strata of the Mississippian System that consist primarily of beds of limestones and shales (table 7). The Chattanooga Shale of Late Devonian and Early Mississippian age lies at the base of the Mississippian-age limestones. The Chattanooga Shale unconformably overlies strata of the Simpson Group of the Ordovician Series, which are underlain by as much as $1,500 \mathrm{ft}$ of Arbuckle Group dolomites of the Upper Cambrian Series (Beckwith, 1928; table 7). 


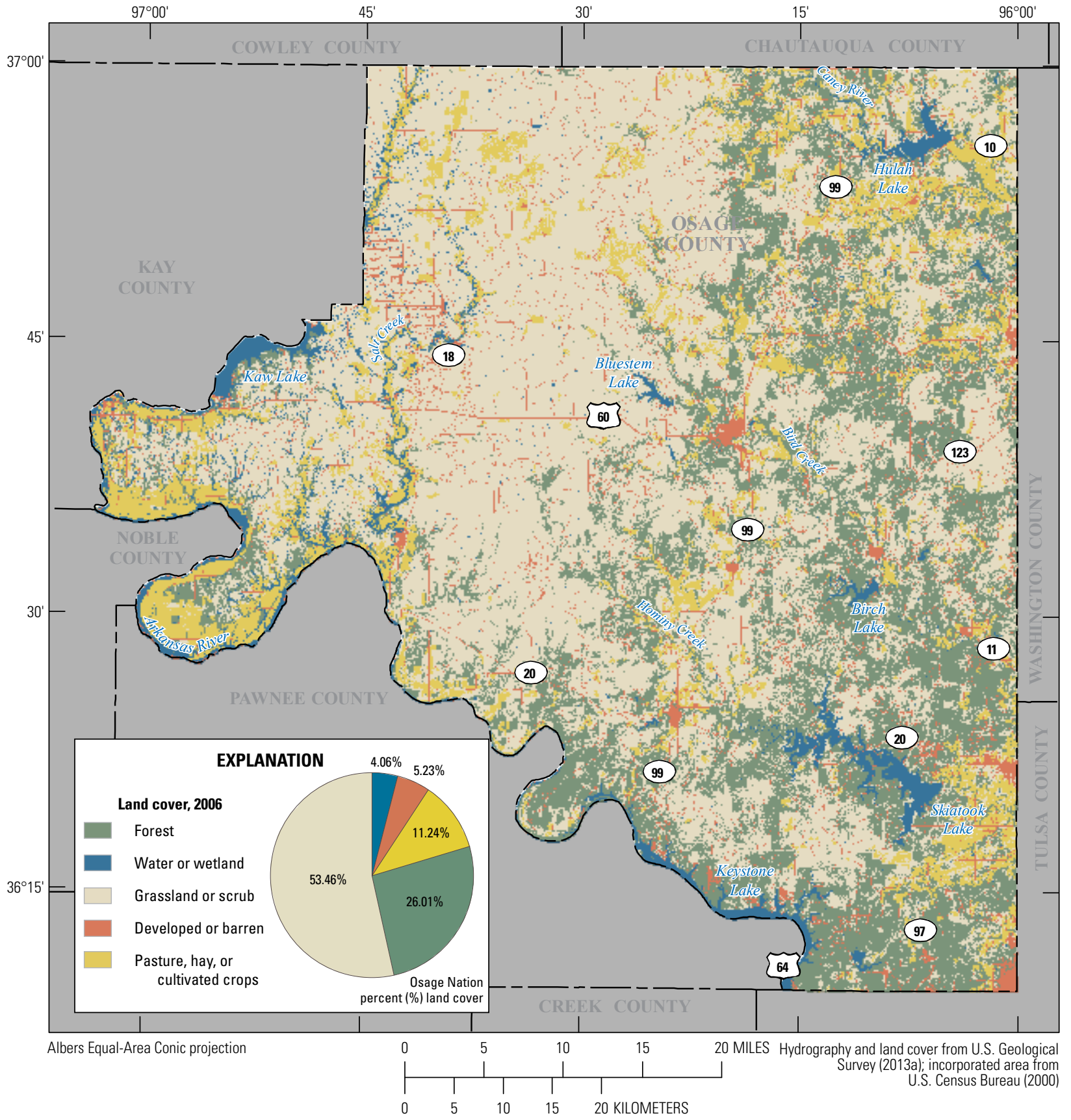

Figure 3. Land cover and percentages of land-cover classes in the Osage Nation, northeastern Oklahoma, 2006. 


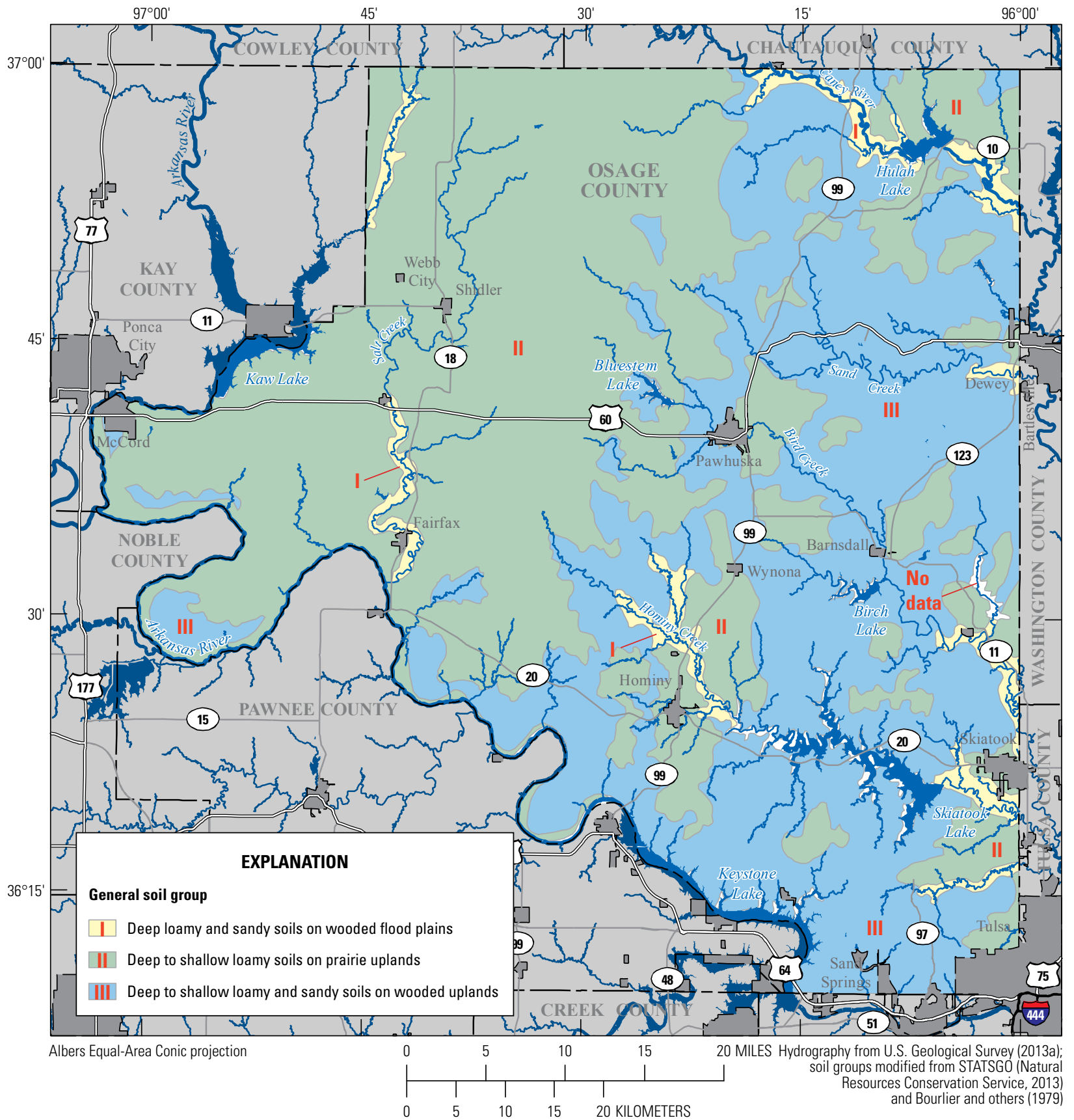

Figure 4. Generalized soil groups in the Osage Nation, northeastern Oklahoma. 


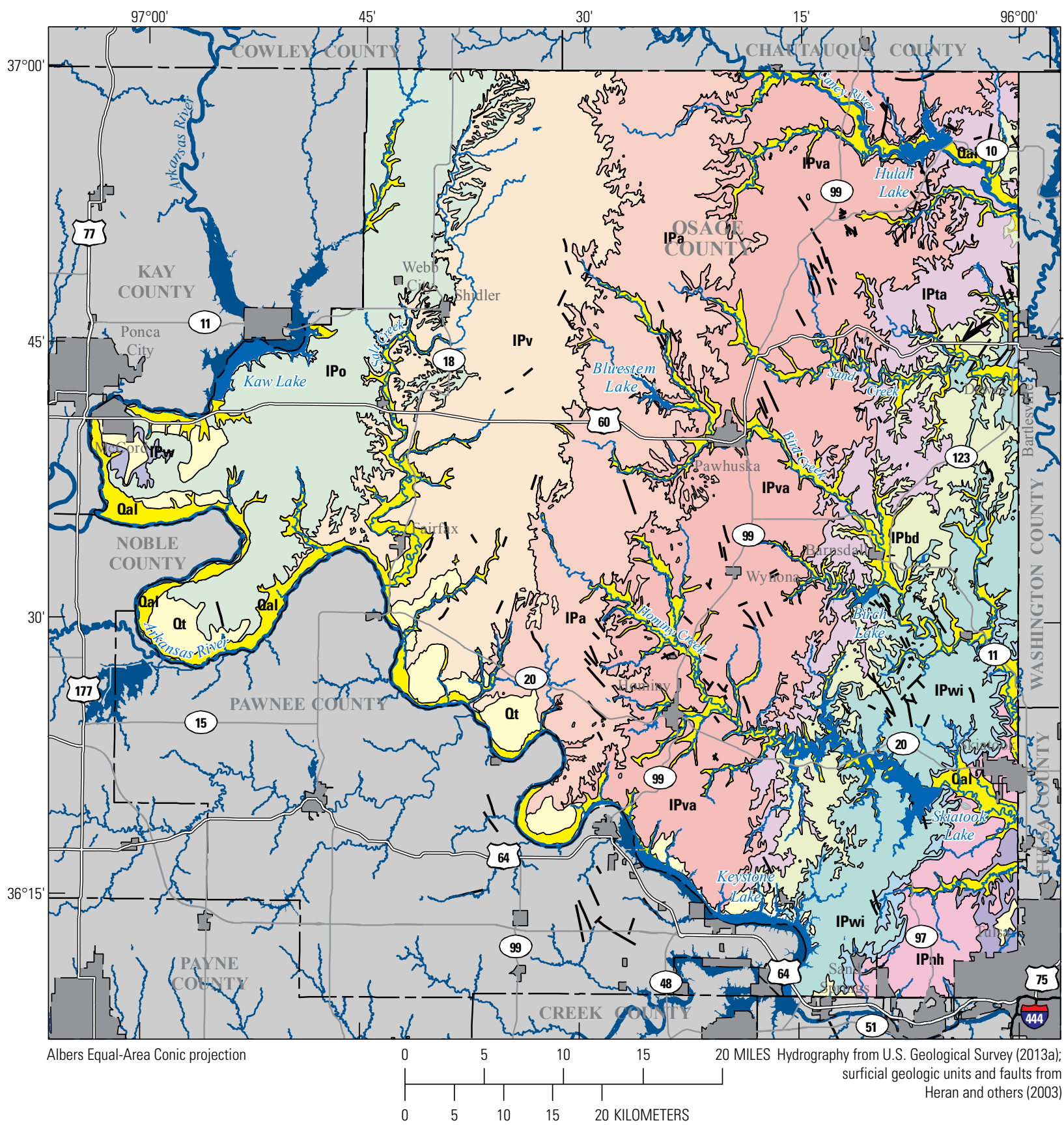

EXPLANATION

Surficial geologic unit

Quaternary

$\square$ Alluvium (Qal)

$\square$ Terrace (0t)

Permian

$\square$ Wellington Formation (Pw)
Pennsylvanian

$\square$ Oscar Group (IPo)

Vanoss Group (IPv)

Ada Group (IPa)

Vamoosa Formation (IPva)

Tallant Formation (IPta)
- Mapped fault

Barnsdall Formation (IPbd)

Wann Formation and lola Limestone (IPwi) Chanute Formation (IPch)

Dewey Limestone (IPd)

Nellie Bly Formation and Hogshooter Limestone (IPnh)

Coffeyville Formation (IPcc)

Figure 5. Surface geology in the Osage Nation, northeastern Oklahoma. 
Table 7. Major stratigraphic units in the Osage Nation, northeastern Oklahoma.

[ft, feet; Fm., Formation; Sh., shale; Ss., sandstone; Ls., limestone; --, unknown; Dol., dolomite; lithology listed in order of prominence in formation. Modified from Beckwith, 1928; Lee and others, 1948; Bingham and Bergman, 1980; D’Lugosz and others, 1986; Shields, 1993; Abbott, 2000; Mashburn and others, 2003; DeHay and others, 2004; Carlucci and Westrop, 2009; Christenson and others, 2011]

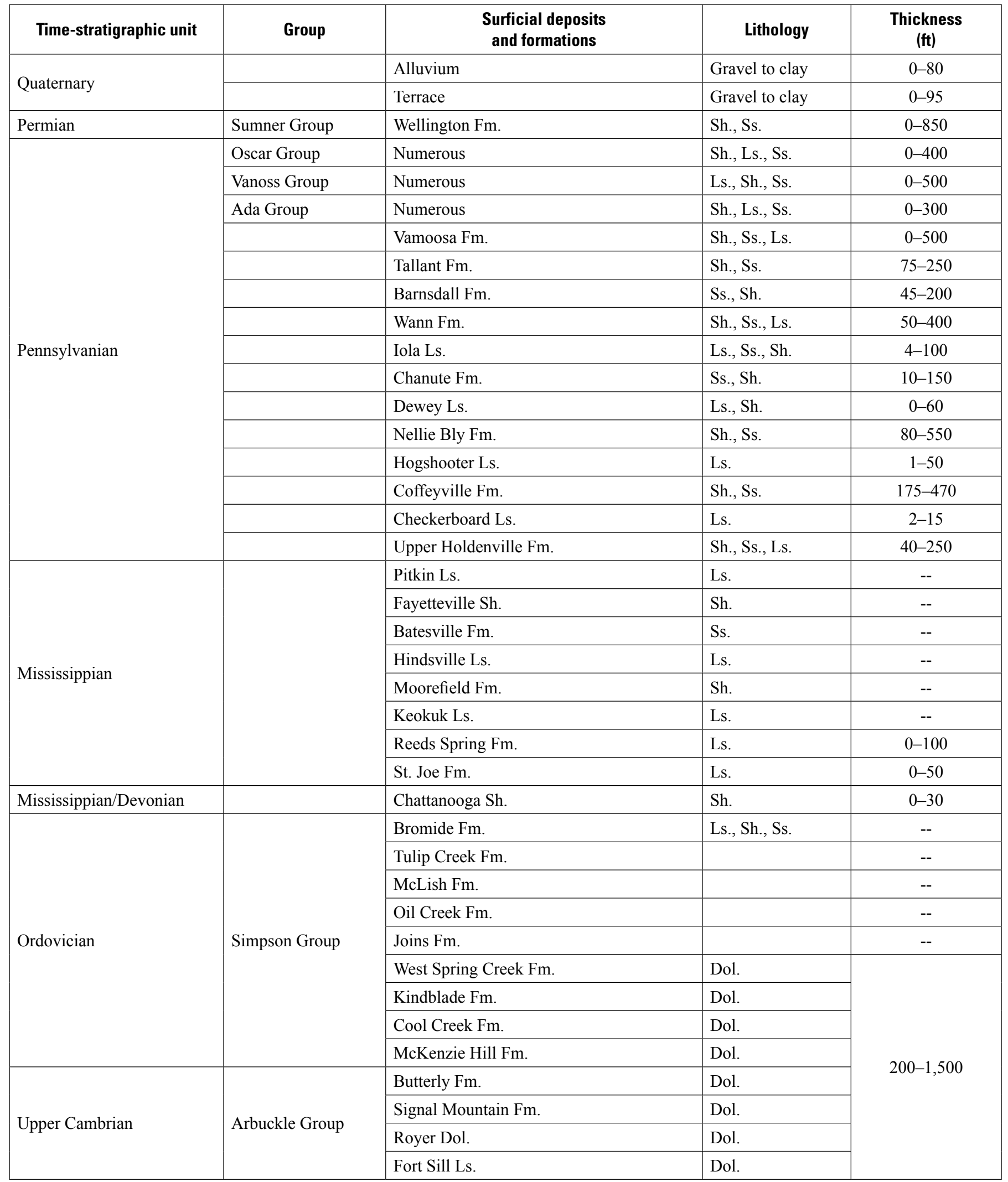


Alluvial aquifers adjoining rivers and streams in the Osage Nation consist of unconsolidated lens-shaped beds of sand, silt, clay, and gravel. Alluvium underlies river valleys and adjoins active stream channels, whereas terrace aquifers are at higher elevations and were deposited when the river bed was at a higher elevation. Alluvial aquifers overlie about $315 \mathrm{mi}^{2}$ of the 2,260-mi land area of the Osage Nation (fig. 5) and range in thickness from zero to $80 \mathrm{ft}$ (Bingham and Bergman, 1980; Abbott, 2000). Terrace aquifers near the Arkansas River, which are grouped with alluvial aquifers in this report, range in thickness from zero to about $95 \mathrm{ft}$ (Mashburn and others, 2003).

The bedrock units of the Pennsylvanian System that underlie or adjoin alluvial aquifers in the Osage Nation vary in thickness from 2,000 to 2,200 ft (Beckwith, 1928). The Vamoosa-Ada aquifer, the most productive bedrock aquifer in the Osage Nation, consists principally of the Vamoosa Formation and the overlying Ada Group. The Vamoosa-Ada aquifer underlies about $800 \mathrm{mi}^{2}$ of the land surface trending almost north-south near the center of Osage County (Abbott, 2000; fig. 5) and consists of stacked sequences of fine grained to very fine grained sandstone, siltstone, shale, and conglomerates that are interbedded with very thin limestones (D'Lugosz and others, 1986). The eastern outcrop edge of the aquifer is defined by the contact of the Vamoosa Formation with the underlying Tallant Formation. The western edge of the aquifer is defined in the subsurface by the location where the dissolved solids concentration of groundwater exceeds 1,500 mg/L (D'Lugosz and others, 1986), three times the secondary drinking-water standard (U.S. Environmental Protection Agency, 2013b). The flow of groundwater through the rocks is controlled by variations in permeability related to changes in lithology, sandstone thickness, and faulting (D’Lugosz and others, 1986). In parts of the Osage Nation where the alluvial or Vamoosa-Ada aquifers are absent, wells produce water from permeable rocks that occur intermittently in the subsurface. These minor bedrock aquifers are associated with nine sedimentary rock units of Pennsylvanian through Permian age (the Coffeyville Formation, the Nellie Bly Formation, the Chanute Formation, the Wann Formation, the Barnsdall Formation, the Tallant Formation, the Vanoss Group, the Oscar Group [also known as the Chase, Council Grove, and Admire Groups], and the Wellington Formation) (Bingham and Bergman, 1980; Shields, 1993; Abbott, 2000). Wells completed in these minor aquifers typically produce less than 25 gallons per minute and underlie about $845 \mathrm{mi}^{2}$ of this area (Bingham and Bergman, 1980; Abbott, 2000; fig. 5).

Deeper parts of the Pennsylvanian System strata and the underlying strata of Mississippian age typically contain saline water, petroleum, and natural gas, with the Mississippi lime play drawing recent interest for recovery of petroleum and natural gas through horizontal drilling and hydraulic fracturing (Boyd, 2011). All freshwater aquifers in the Osage Nation are susceptible to being contaminated by brines from natural seepage or from extraction activities associated with the approximately 40,000 petroleum and natural-gas wells previously or currently in operation in this area (Kharaka and Otton, 2003; Mashburn and others, 2003).

\section{Streamflow and Surface-Water Quality}

Long-term trends and seasonality of monthly mean streamflow are described in this section of the report for three USGS streamflow-gaging stations: Hominy Creek near Hominy, Okla.; Bird Creek at Avant, Okla.; and Arkansas River at Ralston, Okla. Six groups of water-quality data collected at or near those stations (by sampling agency) and at two other surface-water sites are described (table 2). Loads and yields of selected water-quality constituents at some sites are described.

\section{Long-Term Trends and Seasonality of Streamflow}

At the Hominy Creek near Hominy, Okla., streamflowgaging station, the period of record of streamflow-data collection was much shorter (2003-7) than those of the other two stations. At the Hominy Creek near Hominy, Okla., streamflow-gaging station there was a decrease in monthly mean streamflow from about 60 cubic feet per second $\left(\mathrm{ft}^{3} / \mathrm{s}\right)$ in 2003 to about $4 \mathrm{ft}^{3} / \mathrm{s}$ in the spring of 2006 (a period of severe drought; Tortorelli, 2008) and then an increase to about $80 \mathrm{ft}^{3} / \mathrm{s}$ in 2007 (fig. 6). Monthly mean streamflow at the Bird Creek at Avant, Okla., streamflow-gaging station increased from the late 1970 s to 1990 from 40 to about $140 \mathrm{ft}^{3} / \mathrm{s}$. Monthly mean streamflow at that station subsequently decreased to about $70 \mathrm{ft}^{3} / \mathrm{s}$ in 2013 (fig. 6). At the Arkansas River at Ralston, Okla., streamflow-gaging station, monthly mean streamflow gradually increased in the late 1970 s from about $1,800 \mathrm{ft}^{3} / \mathrm{s}$ to a peak of about $5,000 \mathrm{ft}^{3} / \mathrm{s}$ in 2000 , with a subsequent decrease to about 2,500 ft $3 / \mathrm{s}$ by late 2012 (fig. 6). Streamflow from the late 1970s to 1990 at these latter two streamflowgaging stations increased by factors of about 2.8 and 2.2, respectively, with the peak of average monthly mean streamflow increasing by a factor of 2.8 by 2000 at the Arkansas River at Ralston, Okla., streamflow-gaging station (fig. 6). This pattern of increasing streamflows from the late 1970s to the 1990-2000 period at these streamflow-gaging stations (referred to as "stations" in the remainder of this report) likely was the result of a slight increase in precipitation during this period and is similar to the time-series pattern of annual departures from median annual streamflow at other stations in north-central Oklahoma such as the Salt Fork of the Arkansas River at Tonkawa, Okla., and the Chikaskia River near Blackwell, Okla., stations (Shivers and Andrews, 2013). 
A. Hominy Creek near Hominy, Okla. (07176950), Oct. 2003-Sept. 2007

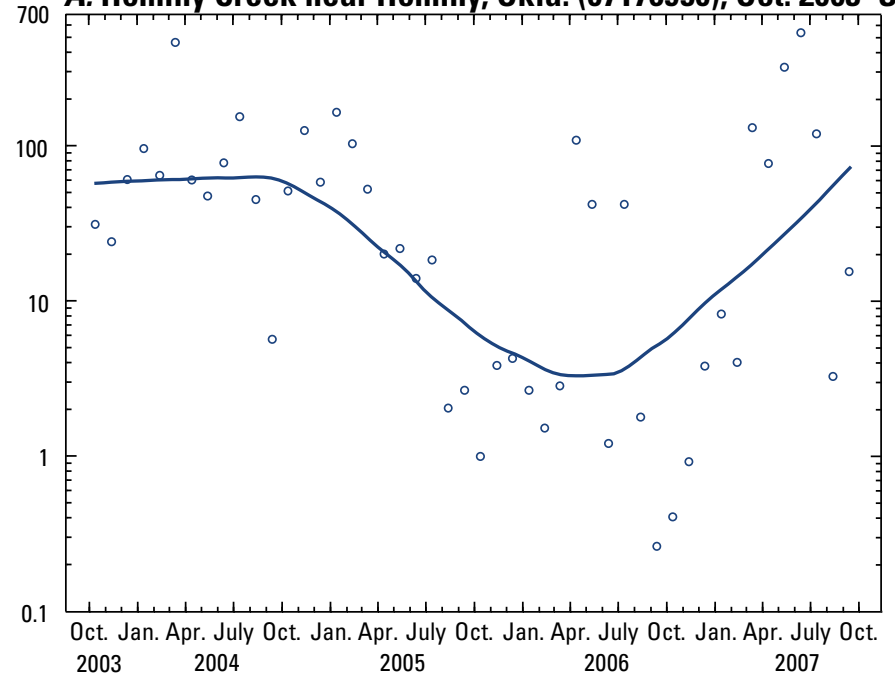

EXPLANATION

- Monthly mean streamflow

Locally estimated scatterplot smoothing line (Cleveland and Devlin, 1988)
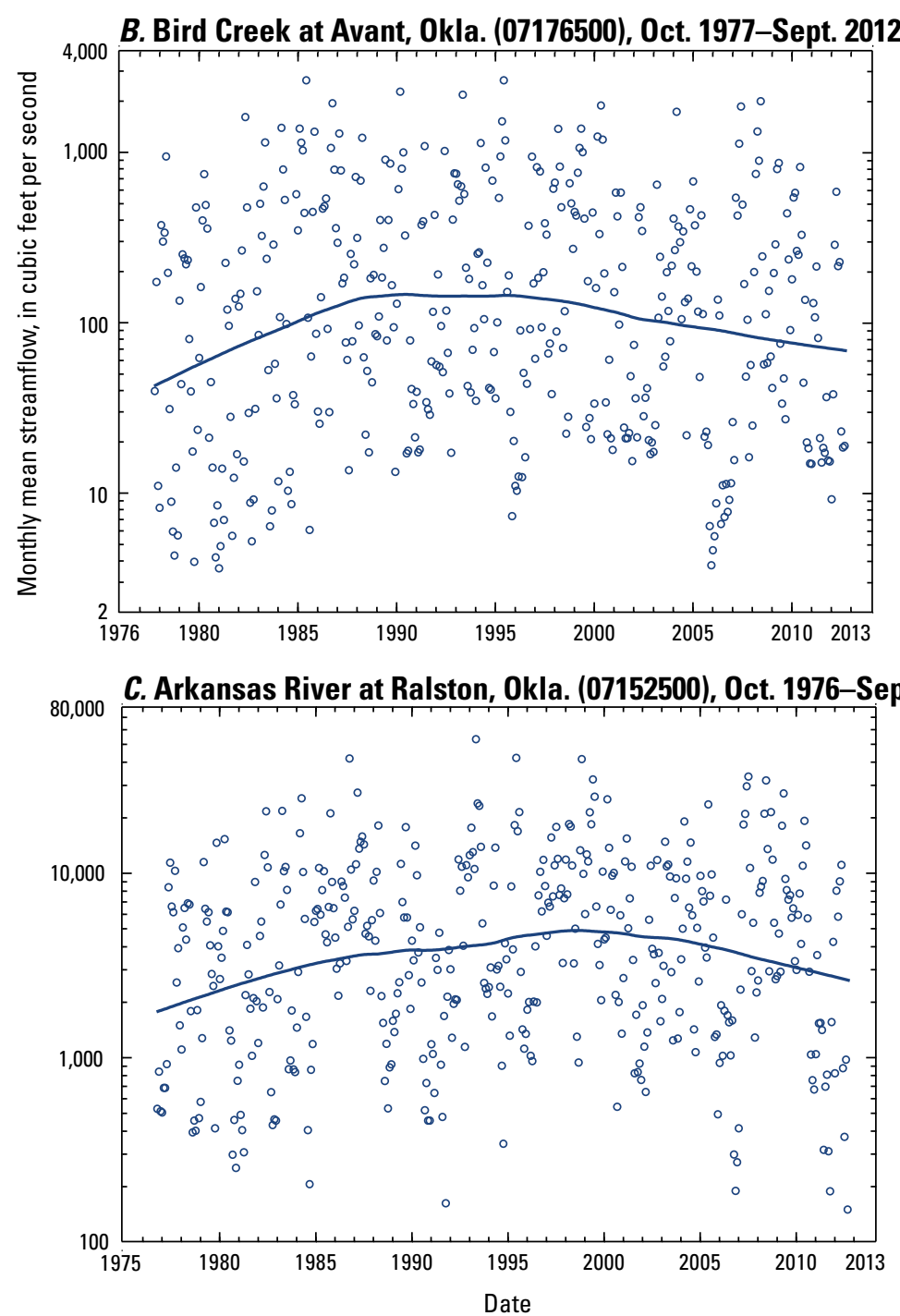

Figure 6. Trends in monthly mean streamflow at three long-term streamflow-gaging stations in or near the Osage Nation, northeastern Oklahoma, October 1976 through September 2012. 
Similar to seasonal patterns of precipitation described previously, monthly mean streamflows at the three stations in the Osage Nation generally were greatest in the spring (March-May) (fig. 7). At the two stations with smaller streamflows, Hominy Creek near Hominy, Okla., and Bird Creek at Avant, Okla., monthly mean streamflows were similar in fall, winter, and summer (fig. 7). At the Arkansas River at Ralston, Okla., station the largest monthly mean streamflows were measured in the spring and summer with the smallest monthly mean streamflows being measured in fall and winter. Substantial monthly mean streamflows in the Arkansas River at that station during the summer (fig. 7) may have been caused by release of water from Kaw Lake upstream.

\section{Surface-Water Quality}

Concentrations of selected water-quality constituents (dissolved oxygen, total dissolved solids, dissolved chloride, and dissolved phosphorus) measured in surface water at three streamflow-gaging stations and two other sites in the Osage Nation from 1999 through 2012 are described in this section (fig. 1, table 2). The USGS and the Osage Nation collected samples at the Hominy Creek near Hominy, Okla., streamflowgaging station at differing dates and differing streamflows.

Median dissolved oxygen concentrations in the water samples collected at the five sampled surface-water sites ranged between 7 and $9 \mathrm{mg} / \mathrm{L}$, with minimum concentrations typically being larger than zero $\mathrm{mg} / \mathrm{L}$ (fig. 8). Such dissolved oxygen concentrations should be sufficient to sustain coldwater and warmwater aquatic biota (Chapman, 1986). Slightly larger dissolved oxygen concentrations were measured at the Bitter Creek and Arkansas River sites than at the other sites. Such large dissolved oxygen concentrations indicate that eutrophication or discharge of other sources of organic material in the streams has not notably impaired surface-water quality at these sites. Those data, however, were collected during daylight hours, when oxygen emitted by photosynthesis of aquatic plants can increase dissolved oxygen concentration by several milligrams per liter; dissolved oxygen concentration can be much smaller at night when plants and bacteria that consume organic wastes take up oxygen through respiration (Huggins and Anderson, 2005; Esralew and others, 2011; U.S. Geological Survey, 2013a). Water-quality sampling of Skiatook, Bluestem, Hulah, and Keystone Lakes in or near the Osage Nation in 2011-12 indicates, on the basis of chlorophyll- $a$ concentration, that lakes in the Osage Nation generally were eutrophic, meaning that they contained large amounts of algae and other aquatic plants (Oklahoma Water Resources Board, 2013c). Skiatook Lake, however, which receives water from Hominy Creek and other tributaries (fig. 1), was rated as being mesotrophic, meaning that only moderate amounts of algae and other aquatic plants were growing in that lake (Oklahoma Water Resources Board, 2013c). In all of those lakes, except for Hulah, dissolved oxygen concentrations in July 2012 were less than $2 \mathrm{mg} / \mathrm{L}$ in part of the water column, indicating limited habitat for aquatic biota (Oklahoma Water Resources Board, 2013c).

Total dissolved solids concentration indicates the quantity of dissolved minerals per unit volume of water. For public water supplies, $500 \mathrm{mg} / \mathrm{L}$ has been set by the EPA as a secondary drinking-water standard because of aesthetic and water-use limitations (U.S. Environmental Protection Agency, 2013b). Water containing more than $500 \mathrm{mg} / \mathrm{L}$ total dissolved solids concentration is likely to cause increased deposits of mineral scale on plumbing fixtures and boilers, coloration, staining, and salty taste (U.S. Environmental Protection Agency, 2013a). The USGS, Osage Nation, OCC, and OWRB measured total dissolved solids concentration in surfacewater samples collected at five sites in the Osage Nation during the period 1999 through 2012 (fig. 9). Total dissolved solids concentrations were significantly larger in the samples collected by the Osage Nation at the Hominy Creek near Hominy, Okla., site than in samples collected by the USGS at that site (fig. 9). About one-third of the samples measured by the USGS were collected at larger streamflows than were the samples collected by the Osage Nation at that site, indicating larger dissolved-solids concentration in groundwater seepage (base flow) than in surface-water runoff (high flow) at that site (fig. 10).

Similar total dissolved solids concentrations were measured in surface-water samples collected by the Osage Nation at the Hominy Creek near Hominy, Okla., and Little Hominy Creek sites and by the OWRB at the Arkansas River at Ralston, Okla., site (fig. 9). The smallest concentrations of total dissolved solids in surface water generally were measured at the Bird Creek at Avant, Okla., site by the OCC. At the Hominy Creek, Little Hominy Creek, and Arkansas River sites, total dissolved solids concentrations in about 25 to 75 percent of the surface-water samples exceeded the secondary drinking-water standard of $500 \mathrm{mg} / \mathrm{L}$ for total dissolved solids, indicating limitations of use of water from those sites for supplying drinking water or other purposes. 
A. Hominy Creek near Hominy, Okla., Oct. 2003-Sept. 2007

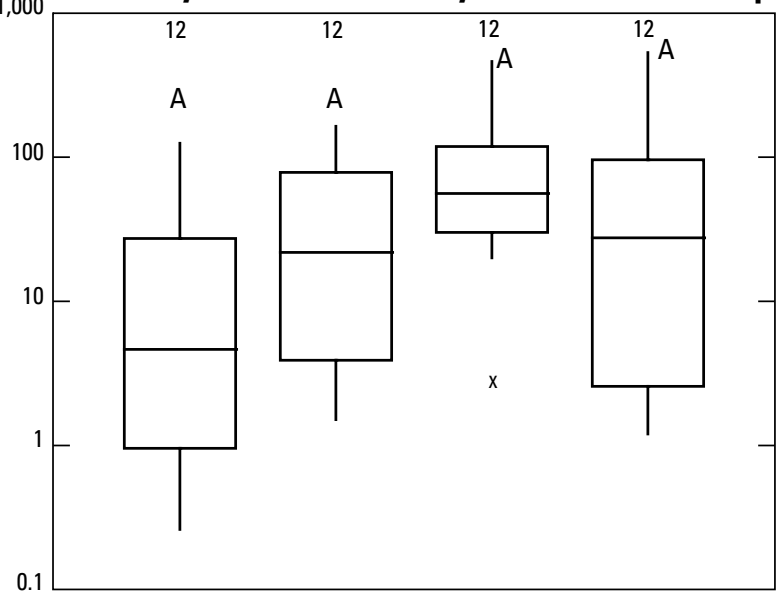

XPLANATION

$30 \quad$ Number of values

A Streamflow distributions with the same letter are not significantly different (p-value greater than $\mathbf{0 . 0 5}$ for the

two-sided Wilcoxon rank-sum test)

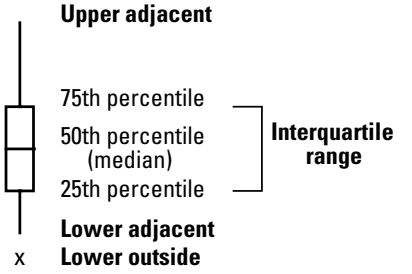

Fall is Sept.-Nov.

Winter is Dec.-Feb.

Spring is Mar.-May

B. Bird Creek at Avant, Okla., Oct. 1977-Sept. 2012

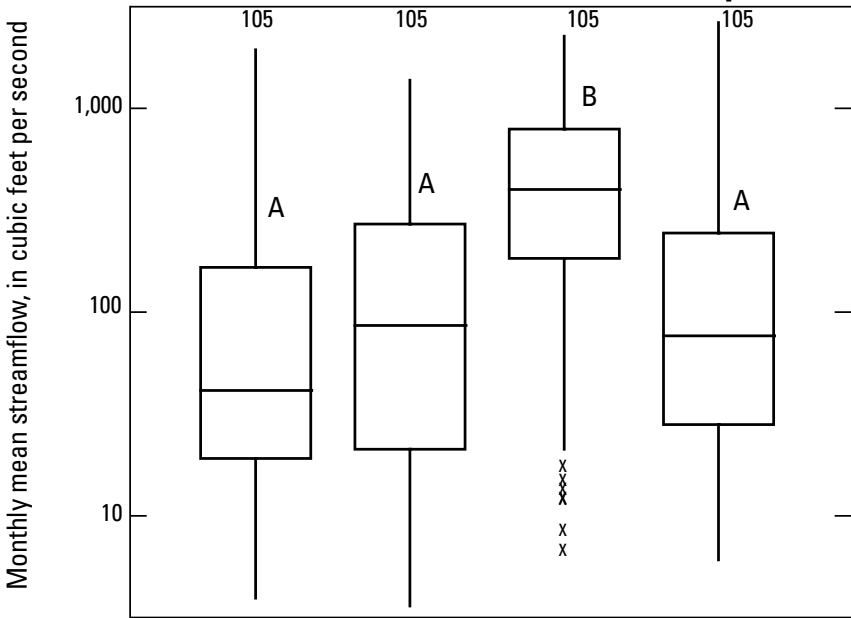

Summer is June-Aug.

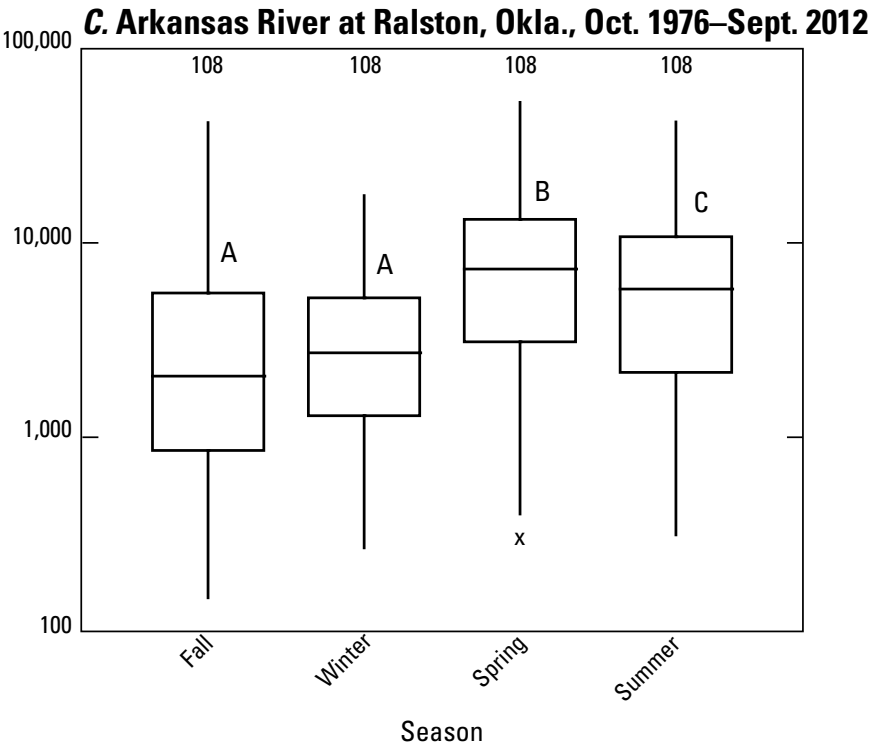

Figure 7. Distributions of monthly mean streamflow by season at three streamflow-gaging stations in the Osage Nation, northeastern Oklahoma, October 1976 through September 2012. 


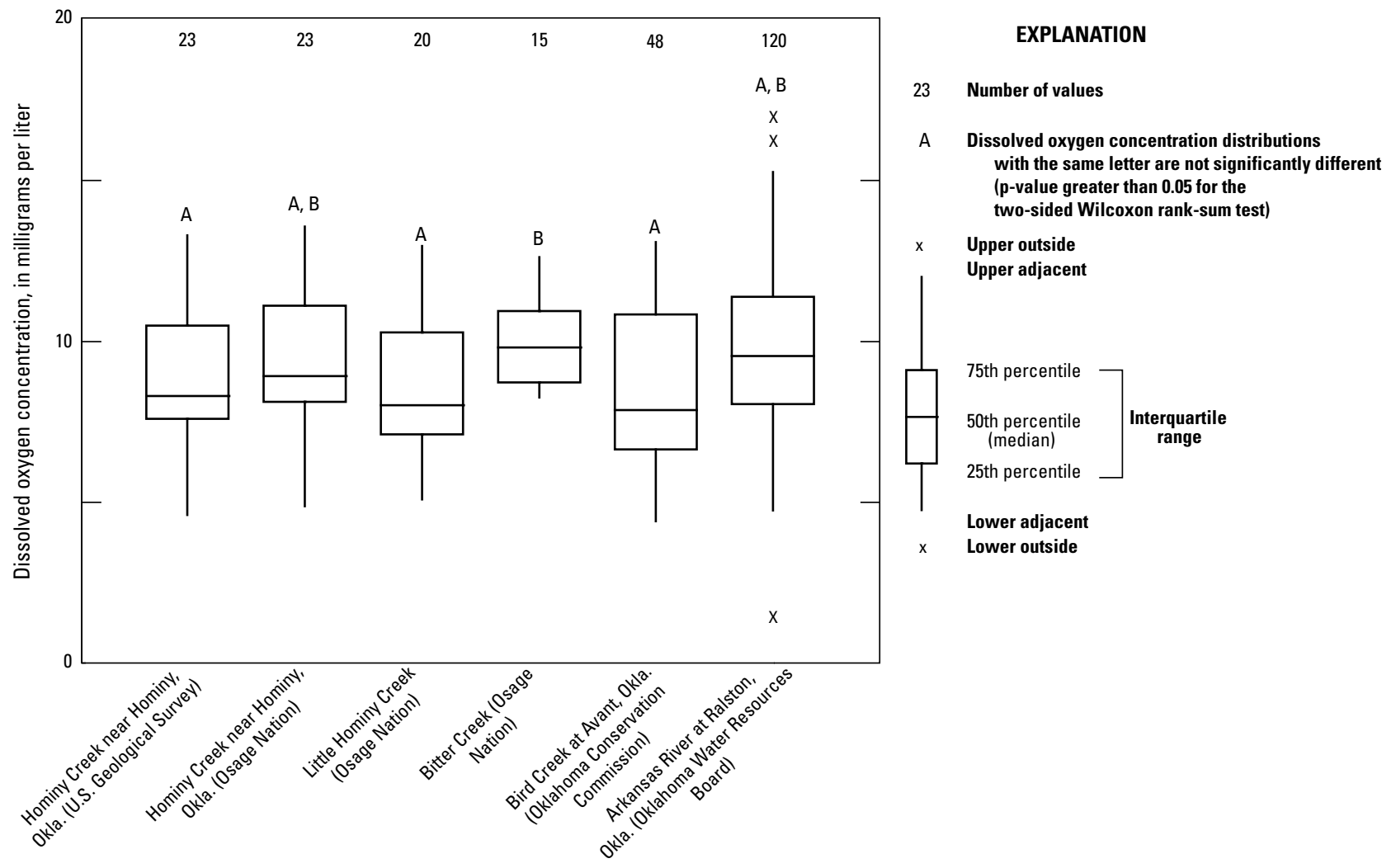

Site name (sampling agency)

Figure 8. Dissolved oxygen concentration in surface-water samples collected at five sites in the Osage Nation, northeastern Oklahoma, 1999 through 2012.

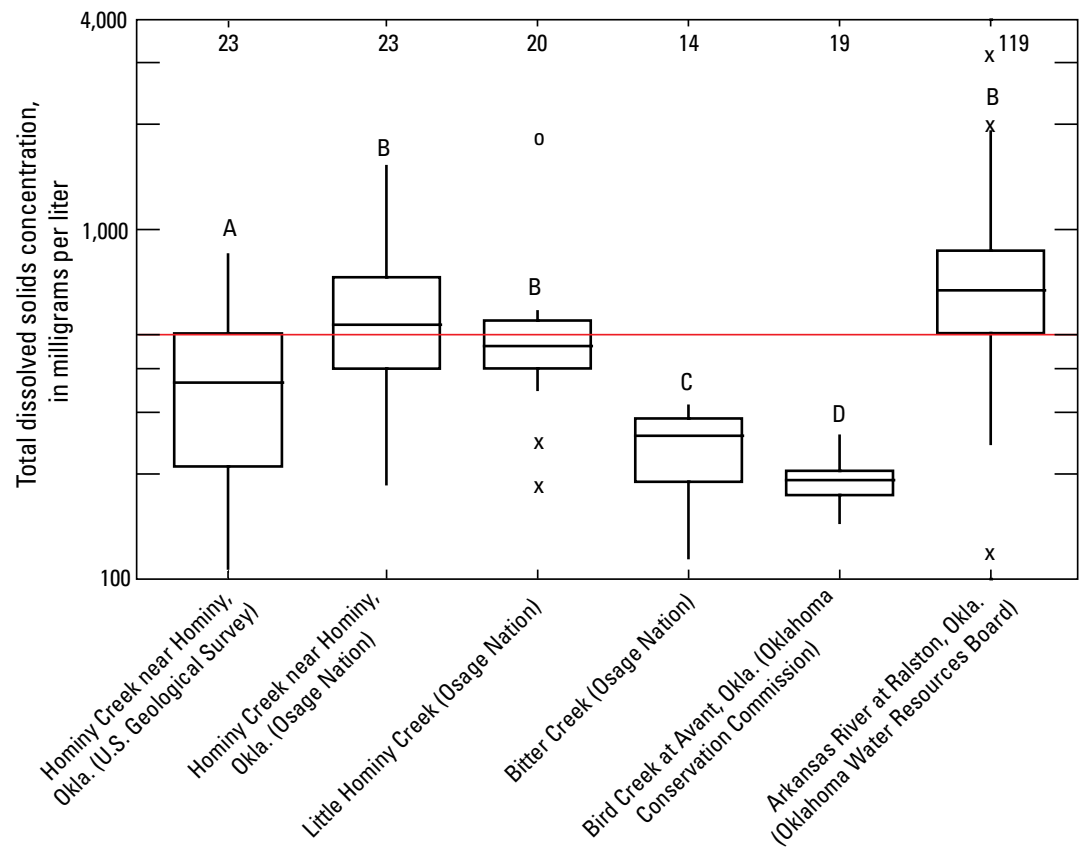

EXPLANATION

23 Number of values

A Total dissolved solids concentration distributions with the same letter are not significantly different ( $\mathrm{p}$-value greater than $\mathbf{0 . 0 5}$ for the two-sided Wilcoxon rank-sum test)

Upper detached

$x \quad$ Upper outside Upper adjacent

Secondary drinking-water standard

(U.S. Environmental Protection Agency, 2013b) 75th percentile 50th percentile
(median) $\quad \begin{gathered}\text { Interquartile } \\ \text { range }\end{gathered}$ 25th percentile

Site name and sampling agency

Figure 9. Total dissolved solids concentration in surface-water samples collected at five sites in the Osage Nation, northeastern Oklahoma, 1999 through 2012. 


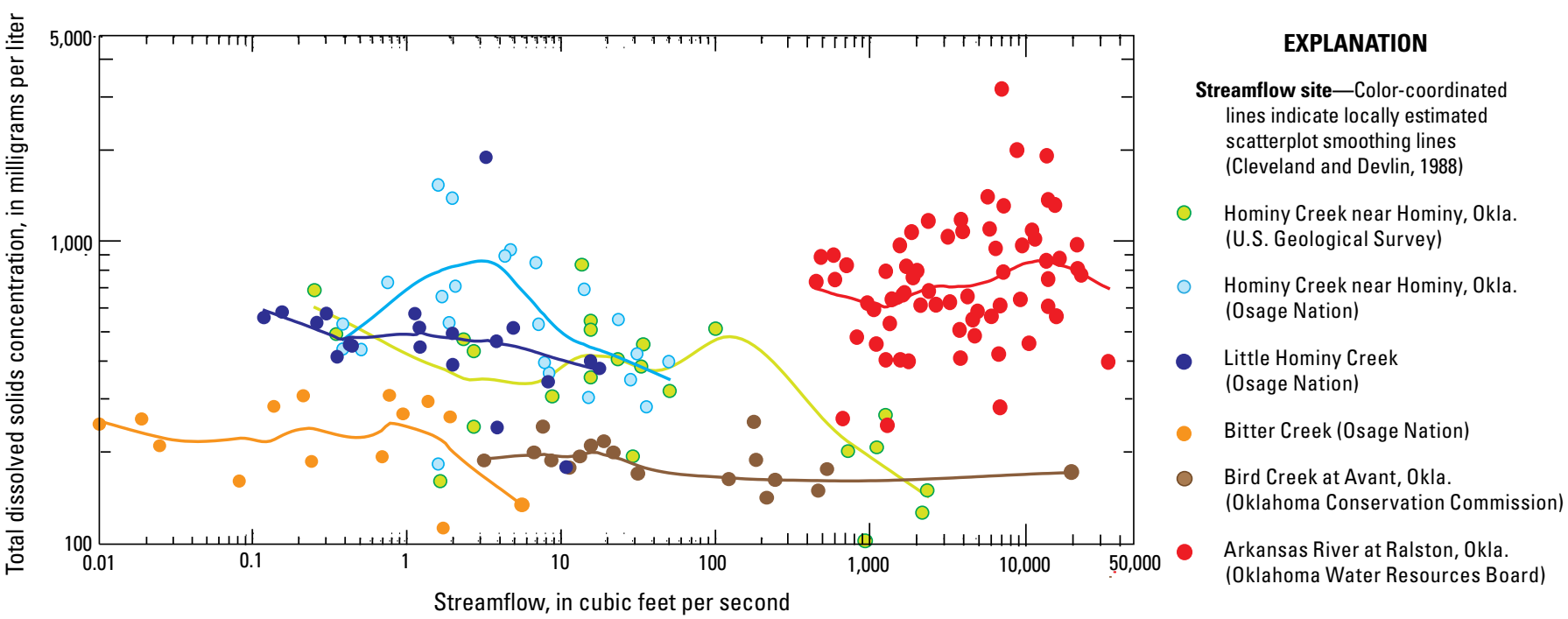

Figure 10. Total dissolved solids concentration with streamflow at five sites in the Osage Nation, northeastern Oklahoma, 1999 through 2012.

In the Osage Nation, chloride in surface water can come from natural upward seepage of brines underlying fresh groundwater and from brines pumped up to the land surface and reinjected or otherwise disposed of as a byproduct of petroleum extraction. Chloride concentration measured in surface water in 1999 at sites distributed throughout much of the Osage Nation generally were greatest in the southern and eastern parts of the area, where the greatest density of numbers of petroleum wells had been drilled (Abbott and Tortorelli, 2002; figs. 1, 11, and 12). About 25 percent of the surfacewater samples collected by the Osage Nation at the Hominy Creek site and by the OWRB at the Arkansas River at Ralston, Okla., site contained dissolved chloride concentrations exceeding the secondary drinking-water standard of 250 $\mathrm{mg} / \mathrm{L}$ set by the EPA (U.S. Environmental Protection Agency, 2013b; fig. 13). That standard was established to minimize salty taste in water used for public water supplies, not because of health problems associated with that concentration or larger concentrations of chloride in drinking water (U.S. Environmental Protection Agency, 2013b). As with total dissolved solids, significantly larger dissolved chloride concentrations were measured in water samples collected at the Hominy Creek near Hominy, Okla., site by the Osage Nation at lower streamflows than in water samples collected at that site by the USGS, probably being related to larger chloride concentrations in groundwater seeping to that stream as base flow (figs. 9, 10, 13, and 14). The smallest dissolved chloride concentrations measured by these agencies at these sites generally were measured in samples collected by the OCC at the Bird Creek at Avant, Okla., site (figs. 13 and 14).

In addition to evaluation of dissolved chloride concentration in surface water, evaluation of dissolved chloride load (the mass of chloride transported downstream in a time period) and dissolved chloride yield (the mass of chloride transported downstream in a time period per unit of upstream watershed area) can indicate areas where larger amounts of chloride discharge to streams. Because of the relatively large dissolved chloride concentrations and streamflows at the Arkansas River at Ralston, Okla., site, compared to the other sites, the greatest dissolved chloride loads were measured at that site (figs. 13 and 14). Because of the much larger watershed area upstream of that site, the dissolved chloride yields of samples collected were similar to those of several of the other sampled sites (fig. 13). Smaller dissolved chloride loads and yields were measured at the Hominy Creek near Hominy, Okla., site (fig. 13). Although slightly larger dissolved chloride concentrations were measured by the Osage Nation at the same Hominy Creek near Hominy, Okla., site than were measured by the USGS during the same period (2003-6), the larger streamflows associated with about one-third of the samples collected by the USGS contributed to significantly larger loads of dissolved chloride being associated with the samples collected by the USGS. Because the upstream watershed area associated with both groups of samples collected by the Osage Nation and the USGS is the same, significantly larger dissolved chloride yields were therefore measured associated with the samples collected by the USGS (fig. 13). Although dissolved chloride loads measured at the Little Hominy Creek site by the Osage Nation were relatively small, the comparatively small area of the Little Hominy Creek watershed made the yields measured at that site the largest of the five sites sampled (fig. 13). The relatively large dissolved chloride yields measured from that small watershed compared to the other watersheds associated with the other sampled sites indicate that there is a particularly large seepage at the surface of saline groundwater or leaks of brines associated with petroleum extraction in that watershed. 


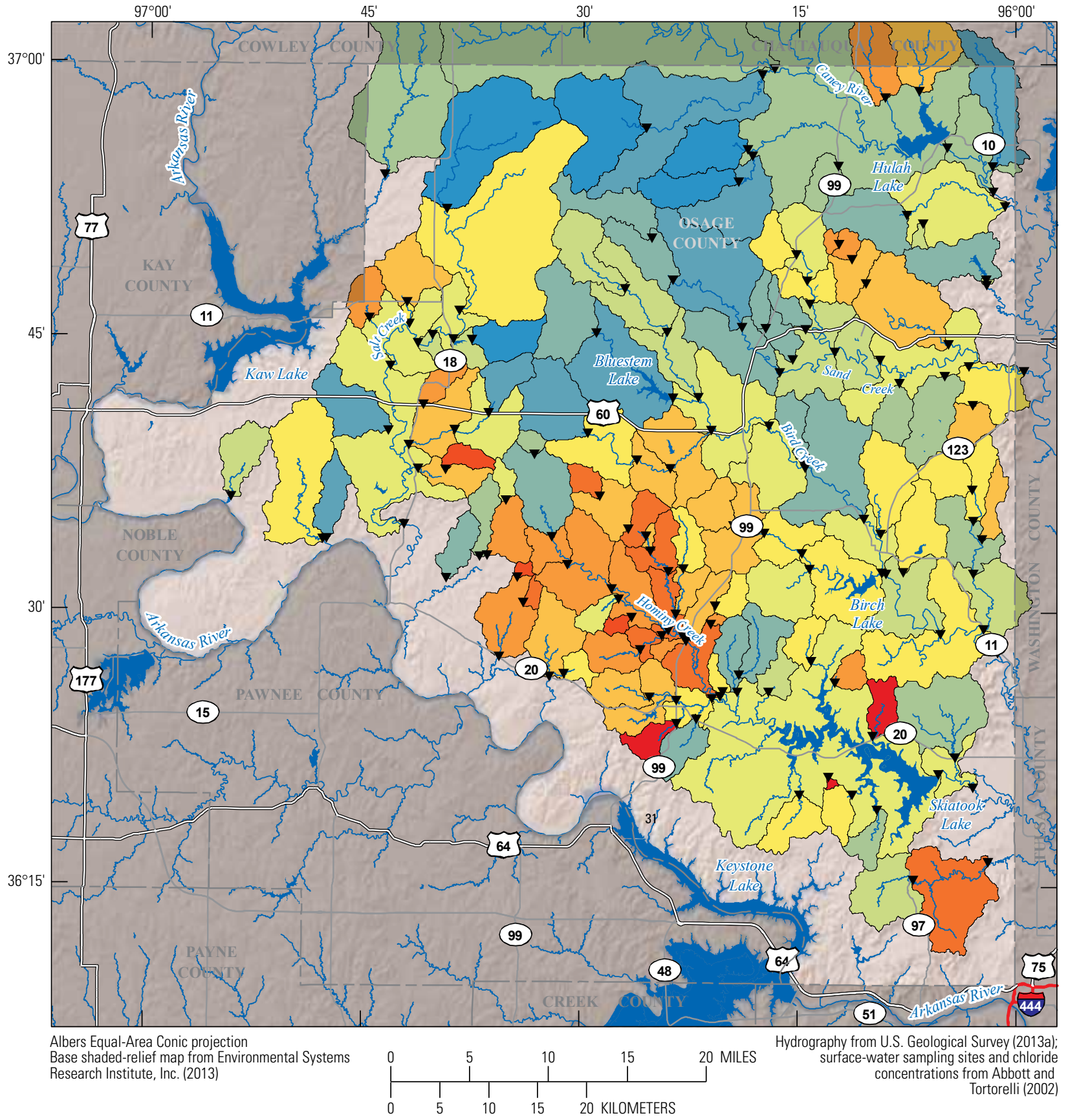

\section{EXPLANATION}

Chloride concentration, in milligrams per liter

\begin{tabular}{|c|c|c|}
\hline $1.99-3.30$ & $14.1-19.4$ & $68.1-130$ \\
\hline $3.31-6.00$ & $19.5-26.0$ & $131-210$ \\
\hline $6.01-10.0$ & $26.1-39.0$ & $211-320$ \\
\hline $10.1-14.0$ & $39.1-68.0$ & $321-1100$ \\
\hline
\end{tabular}

\section{Upstream basin boundary}

\ Surface-water sampling site, 1999

Figure 11. Chloride concentrations measured downstream of selected basins in the Osage Nation, northeastern Oklahoma, 1999. 


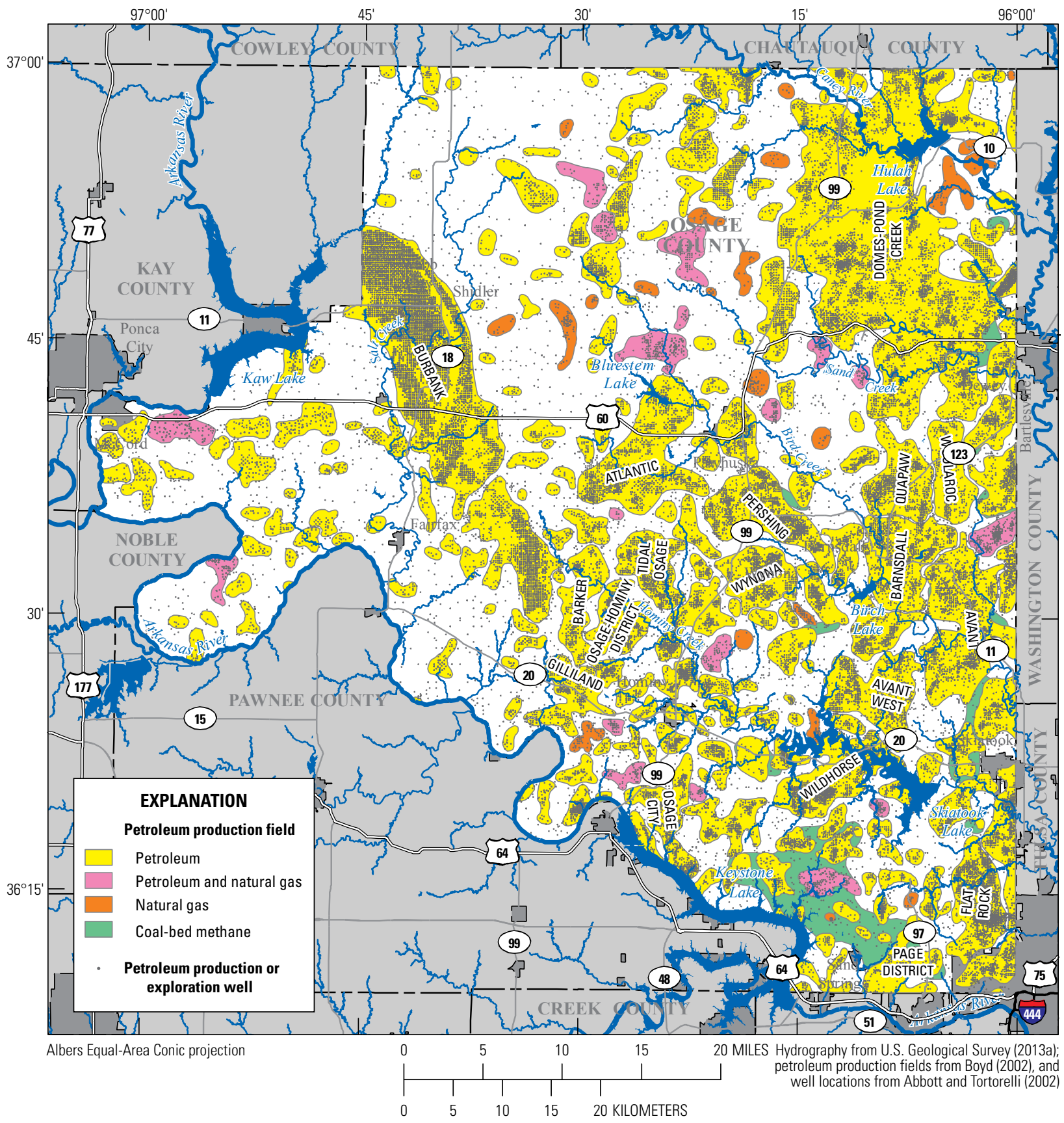

Figure 12. Locations of petroleum and natural-gas wells drilled in the Osage Nation, northeastern Oklahoma, as of 2002. 

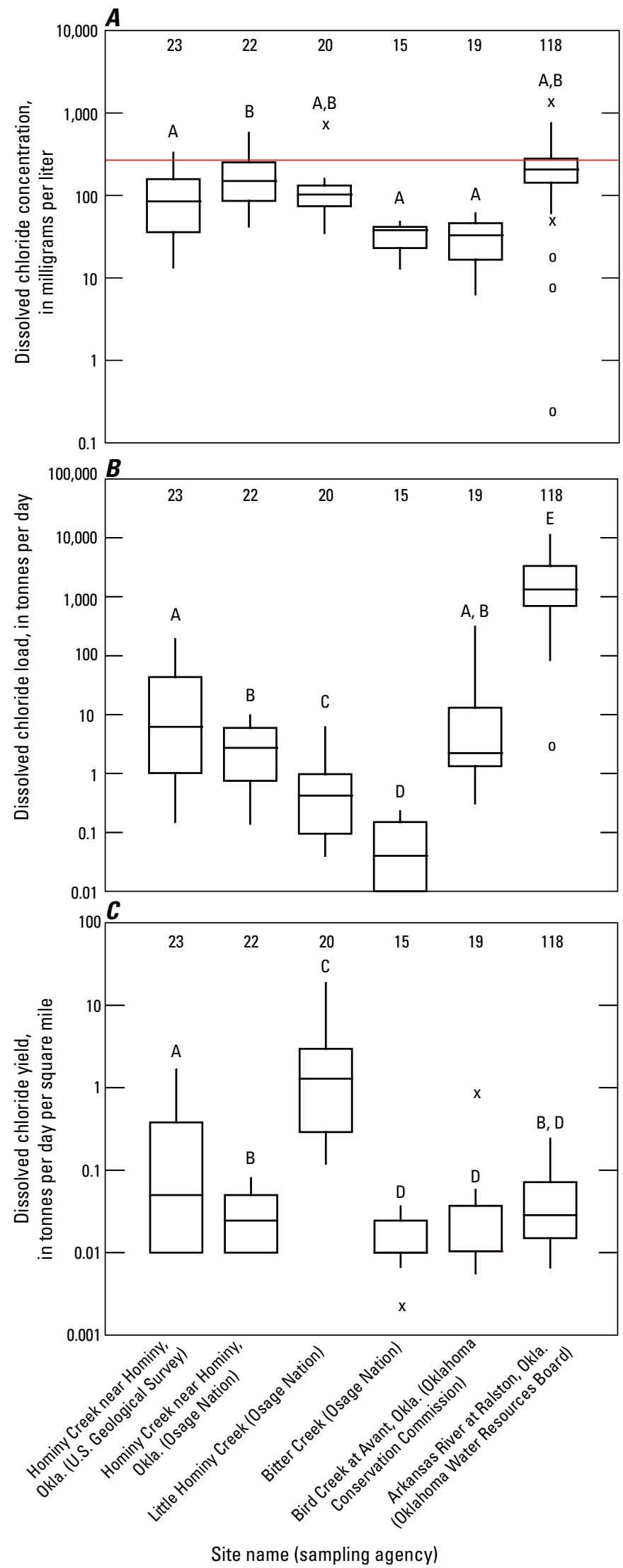

EXPLANATION

30 Number of values

A Constituent distributions with the same letter are not significantly different ( $p$-value greater than 0.05 for the two-sided Wilcoxon rank-sum test)

Upper outside

Upper adjacent

Secondary drinking-water standard

(U.S. Environmental Protection Agency, 2013b)

75th percentile

50th percentile 7 Interquartile

\begin{tabular}{c|c} 
(median) & range \\
25 th percentile &
\end{tabular}

Lower adjacent

Lower outside

Lower detached

Figure 13. Dissolved chloride in surface-water samples collected at five sites in the Osage Nation, northeastern Oklahoma, 1999 through 2012, by $A$, concentrations, $B$, loads, and $C$, yields. 


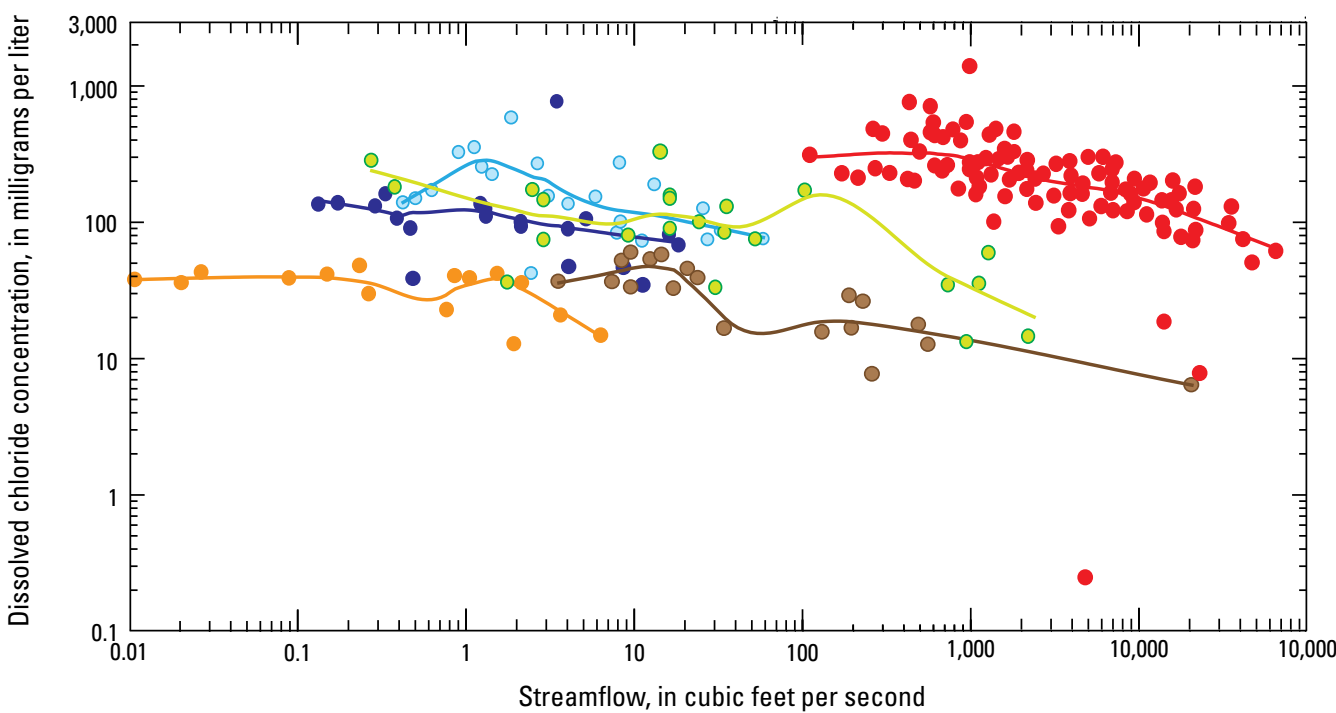

\section{EXPLANATION}

Streamflow site-Color-coordinated lines indicate locally estimated scatterplot smoothing lines (Cleveland and Devlin, 1988)

- Hominy Creek near Hominy, Okla. (07176950) (U.S. Geological Survey)

- Hominy Creek near Hominy, Okla. (Osage Nation)

- Little Hominy Creek (Osage Nation)

- Bitter Creek (Osage Nation)

- Bird Creek at Avant, Okla. (Oklahoma Conservation Commission

- Arkansas River at Ralston, Okla. (Oklahoma Water Resources Board)

Figure 14. Dissolved chloride concentration with streamflow at five sites in the Osage Nation, northeastern Oklahoma, 1999 through 2012.

Phosphorus can seep and run off to streams as a result of natural conditions and human activities. Larger phosphorus concentrations can cause eutrophication, the undesirable growth of aquatic plants, in streams and lakes. Because of the risk of eutrophication of streams and lakes, many States have established water-quality standards for total phosphorus concentration in streams. In Oklahoma, a standard of 0.037 $\mathrm{mg} / \mathrm{L}$ of total phosphorus concentration was established to protect water quality and aquatic habitat in Scenic Rivers (State of Oklahoma, 2006). For comparison, in Wisconsin a standard of $0.075 \mathrm{mg} / \mathrm{L}$ of total phosphorus concentration was established for most streams, with some streams having higher standards of $0.200 \mathrm{mg} / \mathrm{L}$ (State of Wisconsin, 2010). Dissolved phosphorus concentration was measured at two sites, Bird Creek at Avant, Okla., and Arkansas River at Ralston, Okla. The majority of the 137 measured dissolved phosphorus concentrations exceeded the $0.037 \mathrm{mg} / \mathrm{L}$ Oklahoma standard for total phosphorus in Scenic Rivers (fig. 15), with about 35 percent of samples collected at the Bird Creek at Avant, Okla., site and about 90 percent of samples collected at the Arkansas River at Ralston, Okla., site containing dissolved phosphorus concentrations exceeding the $0.075 \mathrm{mg} / \mathrm{L}$ Wisconsin standard for total phosphorus. Dissolved phosphorus concentrations were significantly larger in surface-water samples collected at the Arkansas River at Ralston, Okla., site than in surface-water samples collected at the Bird Creek at Avant, Okla., site (fig. 15). Such relatively large dissolved phosphorus concentrations in those samples in comparison to surface-water-quality standards indicate that eutrophication was likely to occur in the Arkansas River and Bird Creek at those sampled sites (with eutrophication in flowing streams usually being dominated by periphyton, algae growing on solid surfaces) or in lakes receiving these waters (with eutrophication in lakes usually being dominated by phytoplankton, algae growing predominantly near the top of the water column) (Andrews and others, 2009). With larger streamflows in the Arkansas River relative to Bird Creek at the time of collection of most water-quality samples (figs. 6 and 16), dissolved phosphorus loads at the Arkansas River at Ralston, Okla., site were significantly larger than those at the Bird Creek at Avant, Okla., site (fig. 15). Because of the much larger watershed area upstream of the Arkansas River at Ralston, Okla., site, however, dissolved phosphorus yields were not significantly different at these two sites (fig. 15).

Unlike chloride, which tends to be measured at larger concentrations in base flow in local streams, dissolved phosphorus concentration substantially increased with increasing streamflow (fig. 16). Increasing dissolved phosphorus concentration with increasing streamflow indicates that runoff from the land surface carries dissolved phosphorus from eroded soils, animal wastes, and other organic matter on the land surface. In addition, increased streamflow also may resuspend phosphorus associated with streambed sediments, as described in Andrews and others (2009) for the Illinois River watershed in northeastern Oklahoma. The strong correlation between dissolved phosphorus and streamflow in water samples collected at the Bird Creek and Arkansas River sites (fig. 16) may be related to similar soils, topography, and land uses in the watersheds upstream from these sites. 

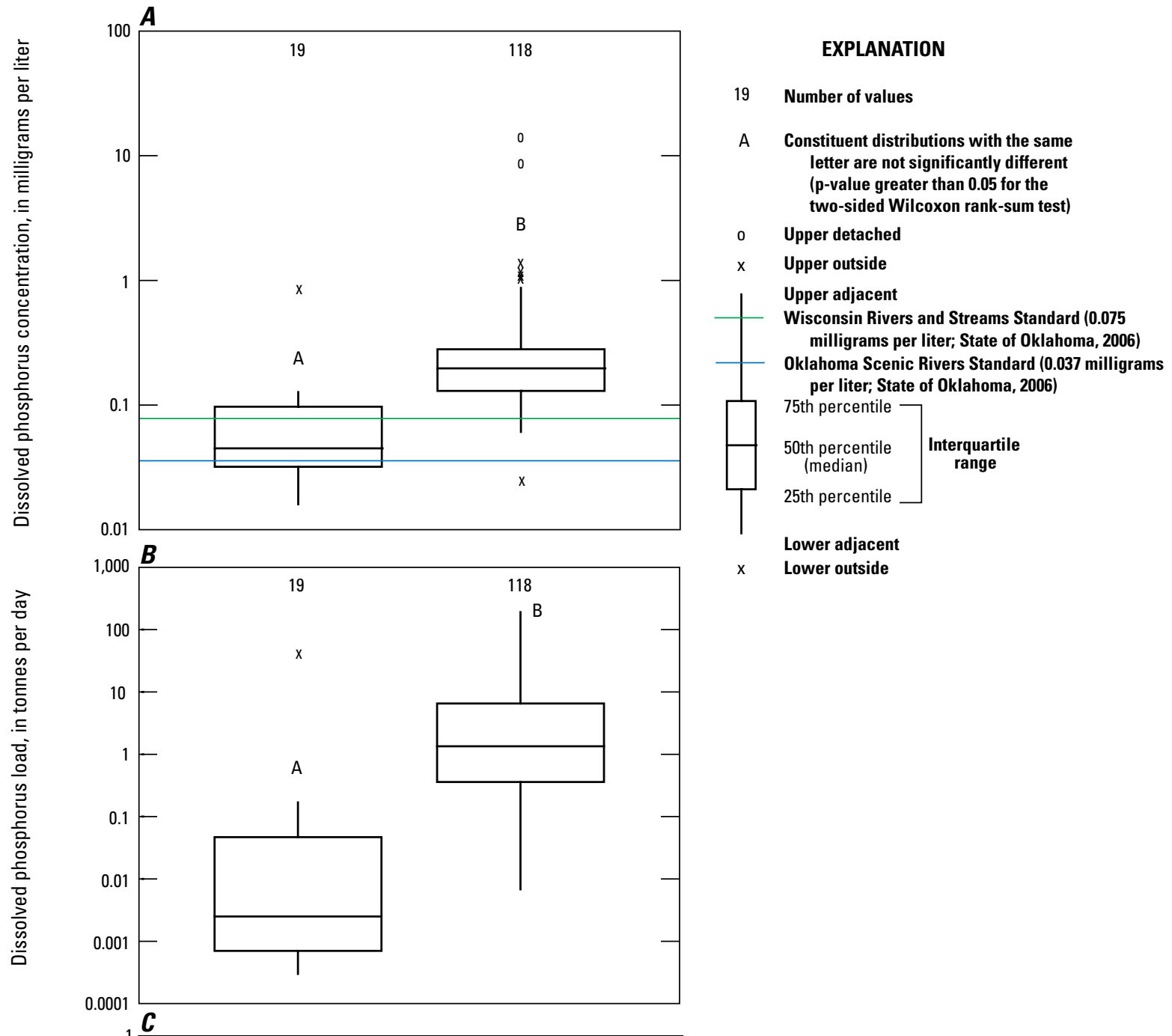

Lower outside

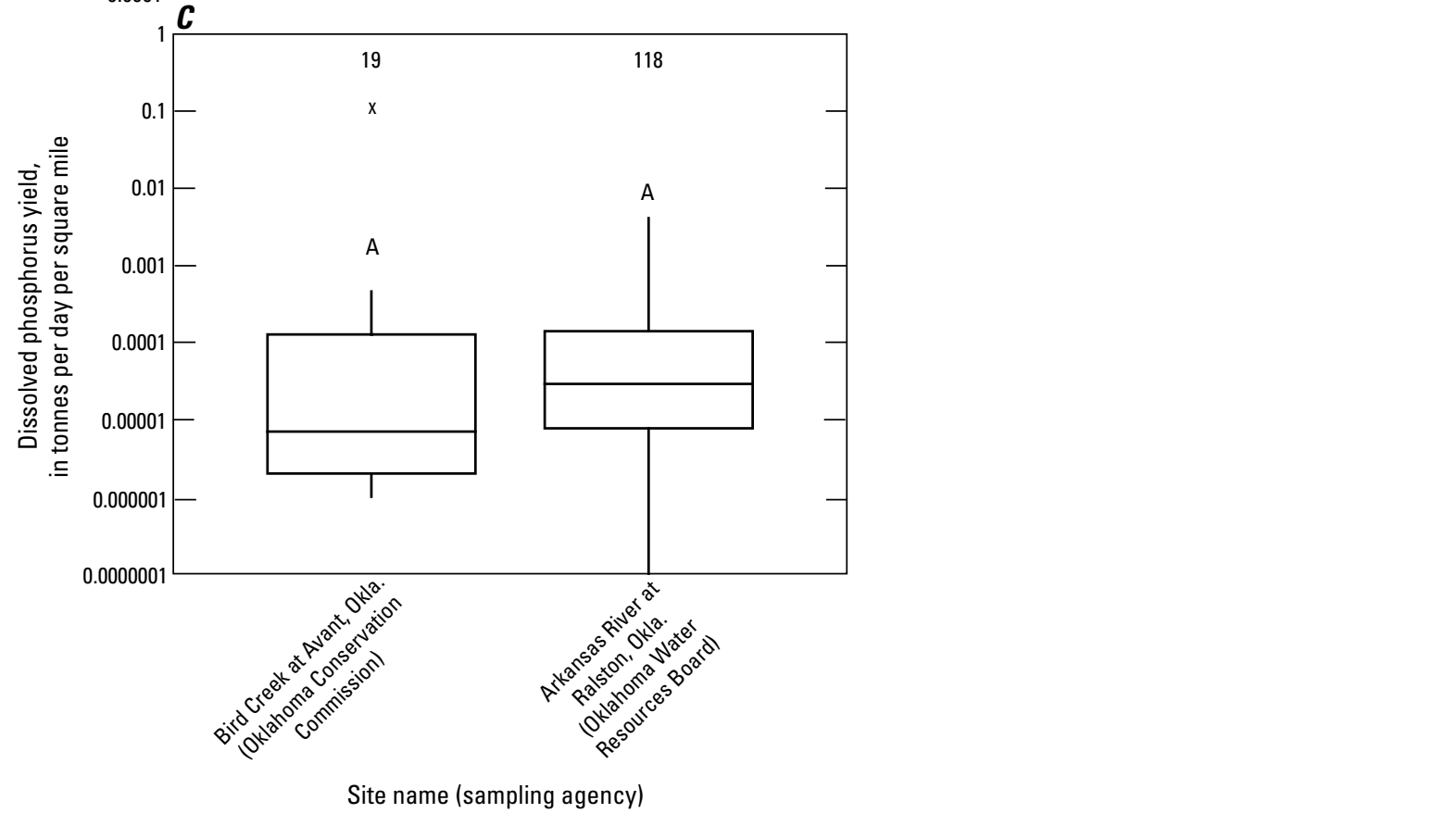

Figure 15. Dissolved phosphorus in surface-water samples collected at two sites in the Osage Nation, northeastern Oklahoma, 1999 through 2012, by $A$, concentrations, $B$, loads, and $C$, yields. 


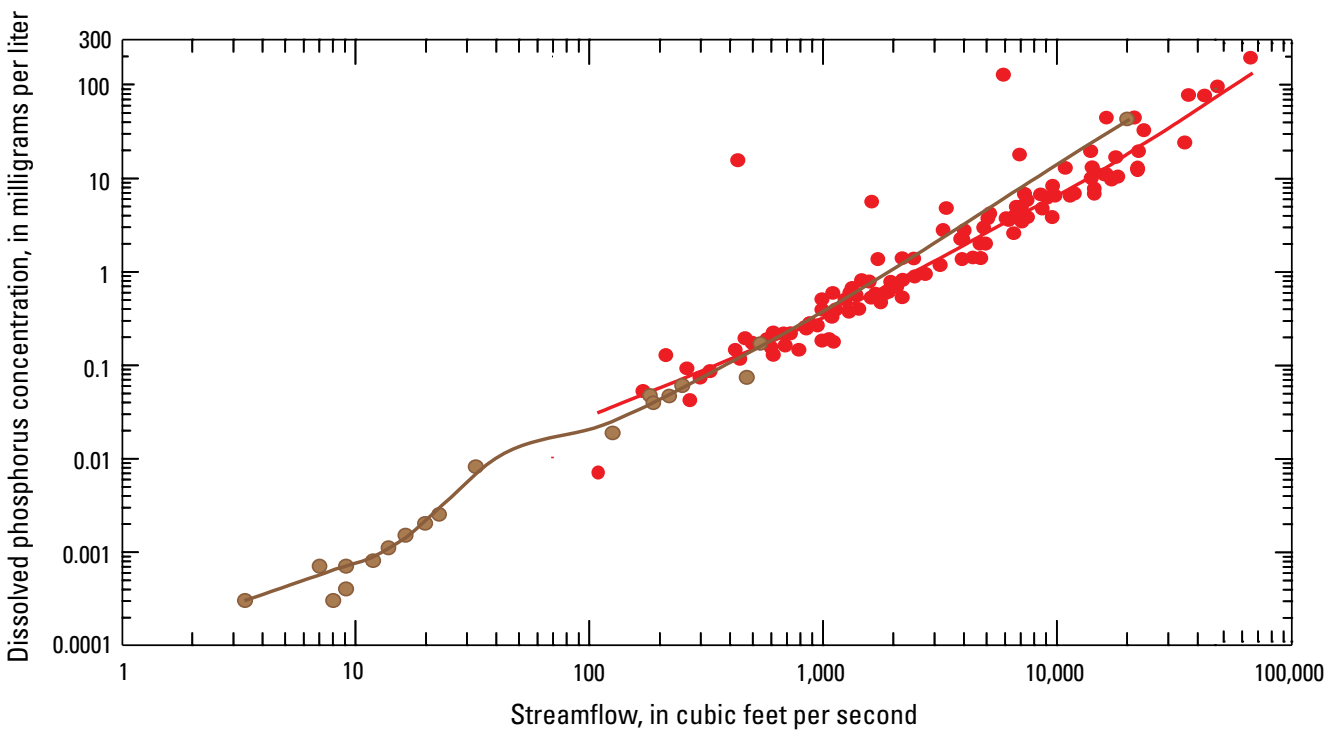

EXPLANATION

Streamflow site-Color-coordinated lines indicate locally estimated scatterplot smoothing lines (Cleveland and Devlin, 1988)

- Bird Creek at Avant, 0kla. (Oklahoma Conservation Commission)

- Arkansas River at Ralston, Okla. (Oklahoma Water Resources Board)

Figure 16. Dissolved phosphorus concentration with streamflow at two sites in the Osage Nation, northeastern Oklahoma, 1999 through 2012.

\section{Groundwater Availability and Quality}

The Osage Nation is underlain by three principal freshwater aquifers: (1) alluvial aquifers, consisting of unconsolidated sands, silts, clays, and gravels deposited along streams and rivers in the Quaternary Period; (2) the Vamoosa-Ada aquifer consisting of a sequence of sandstones, limestones, and shales deposited in marine environments in the Pennsylvanian Period; and (3) minor bedrock aquifers associated with eight sedimentary rock formations deposited in the Pennsylvanian to Permian Periods (Bingham and Bergman, 1980; Shields, 1993; Abbott, 2000; table 8). The supply of potable groundwater in the alluvial aquifers and the Vamoosa-Ada aquifer is adequate for current domestic and other purposes, but in areas where these aquifers are absent, groundwater must be pumped from minor bedrock aquifers that generally produce smaller volumes of water (Bingham and Bergman, 1980).

The western third of the Osage Nation is underlain by alluvial aquifers or minor bedrock aquifers. Groundwater from these aquifers typically contains between 500 and $1,000 \mathrm{mg} / \mathrm{L}$ of total dissolved solids, which can be associated with very hard water (Bingham and Bergman, 1980). Hard water can (1) cause buildup of mineral scale deposits on boilers, water heaters, and plumbing fixtures; (2) stain plumbing fixtures and laundry; and (3) contribute a salty taste to water (U.S. Environmental Protection Agency, 2013b). Bingham and Bergman (1980) reported that groundwater in an approximately $200-\mathrm{mi}^{2}$ area near the northeast corner of the Osage Nation contained concentrations of total dissolved solids generally exceeding $1,000 \mathrm{mg} / \mathrm{L}$ in Pennsylvanian-age rock units other than the Vamoosa Formation.

Table 8. Properties of freshwater aquifers underlying the Osage Nation, northeastern Oklahoma.

[ft, feet; d, day; $\mathrm{ft}^{2}$, square feet; gal/min, gallons per minute; --, not known; <, less than]

\begin{tabular}{|c|c|c|c|c|c|}
\hline Aquifer & $\begin{array}{c}\text { Thickness } \\
\text { range } \\
\text { (ft) }\end{array}$ & $\begin{array}{c}\text { Hydraulic } \\
\text { conductivity range } \\
\text { (ft/d) }\end{array}$ & $\begin{array}{c}\text { Transmissivity } \\
\text { range } \\
\left(\mathrm{ft}^{2} / \mathrm{d}\right)\end{array}$ & $\begin{array}{c}\text { Specific } \\
\text { capacity range } \\
{[(\operatorname{gal} / \mathrm{min}) / \mathrm{ft}]}\end{array}$ & $\begin{array}{c}\text { Well } \\
\text { yield range } \\
\text { (gal/min) }\end{array}$ \\
\hline Alluvial and terrace & ${ }^{1} 0-174$ & ${ }^{2} 2.9-6,000$ & ${ }^{2} 2,000-26,000$ & -- & ${ }^{1} 20-500$ \\
\hline Vamoosa-Ada & ${ }^{1,3} 0-800$ & ${ }^{3} 2-4$ & ${ }^{3} 70-490$ & $<11$ & ${ }^{1,2} 6-55$ \\
\hline Minor bedrock & -- & -- & -- & -- & ${ }^{1,2} 6-15$ \\
\hline
\end{tabular}

${ }^{1}$ Bingham and Bergman (1980).

${ }^{2}$ Mashburn and others (2003).

${ }^{3}$ D’Lugosz and others (1986). 


\section{Groundwater Availability by Aquifer}

Fresh groundwater in the Osage Nation is most abundant in alluvial aquifers along streams and the Vamoosa-Ada aquifer (Bingham and Bergman, 1980). Yields of groundwater from minor bedrock aquifers, which include thin layers of sandstone and limestones, are relatively small (Bingham and Bergman, 1980; fig. 17, table 8).

Mashburn and others (2003) reported that, on the basis of sediment grain-size distribution, the hydraulic conductivity of alluvium along the Arkansas River ranged from about 3 to 6,000 feet per day ( $\mathrm{ft} / \mathrm{d}$ ), with hydraulic conductivities in adjoining terrace aquifers being estimated to range from about 3 to $430 \mathrm{ft} / \mathrm{d}$. That report estimated transmissivities of 2,000 to 26,000 feet squared per day $\left(\mathrm{ft}^{2} / \mathrm{d}\right)$, with a median transmissivity of 5,100 $\mathrm{ft}^{2} / \mathrm{d}$ for the alluvial aquifer along the Arkansas River (table 8). Mashburn and others (2003) also estimated that recharge to that segment of that alluvial aquifer was about 4,800 acre-ft per year (acre-ft/yr).

Underlying permeable rock units more than $1,000 \mathrm{ft}$ below the land surface in most areas of the Osage Nation contain water with total dissolved solids concentration larger than 5,000 $\mathrm{mg} / \mathrm{L}$ (Bingham and Bergman, 1980; D’Lugosz and others, 1986). Such water currently is withdrawn with petroleum extraction, separated gravimetrically, and pumped back down to the same strata through water-flooding wells used to drive residual petroleum to central gathering wells, or is discarded through disposal wells that are about 3,000 ft deep (the typical producing depth in the Burbank Oil Field in this area, as described in Franks, 1989). As mentioned in Bourlier and others (1979), Abbott and Tortorelli (2002), Kharaka and Otton (2003), and U.S. Geological Survey (2013e), brines withdrawn during petroleum and natural-gas extraction can leak to shallow groundwater and streams through spills, through seepage from settling ponds, and from upward migration where surface casing set during petroleum and natural-gas exploration does not extend completely through the freshwater zone. With approximately 40,000 known petroleum and natural-gas wells penetrating the bedrock aquifer in the Osage Nation (fig. 12), there are ample numbers of potential conduits by which brines may seep to shallow aquifers and adjoining streams.

Alluvial aquifers in the Osage Nation are likely to produce relatively large well yields compared to adjoining and underlying bedrock aquifers (table 8; Bingham and Bergman, 1980). The Vamoosa-Ada aquifer, which underlies a large part of the Osage Nation (fig. 17), generally produces smaller well yields than alluvial aquifers (table 8). D'Lugosz and others (1986) described selected properties of the Vamoosa-Ada aquifer in the Osage Nation and counties to the south that can be used for planning purposes. Parts of the Vamoosa-Ada aquifer with larger sandstone thicknesses (fig. 18) are likely to have higher hydraulic conductivities, transmissivities, and well yields than other parts of the aquifer. Such areas are likely to be the most productive for large numbers of wells for domestic or other local uses. Estimated thicknesses of alluvial aquifers in the Osage Nation are relatively small, generally less than $100 \mathrm{ft}$, whereas the thickness of freshwater in the Vamoosa-Ada aquifer can be several hundred feet (figs. 19-21, table 8). 


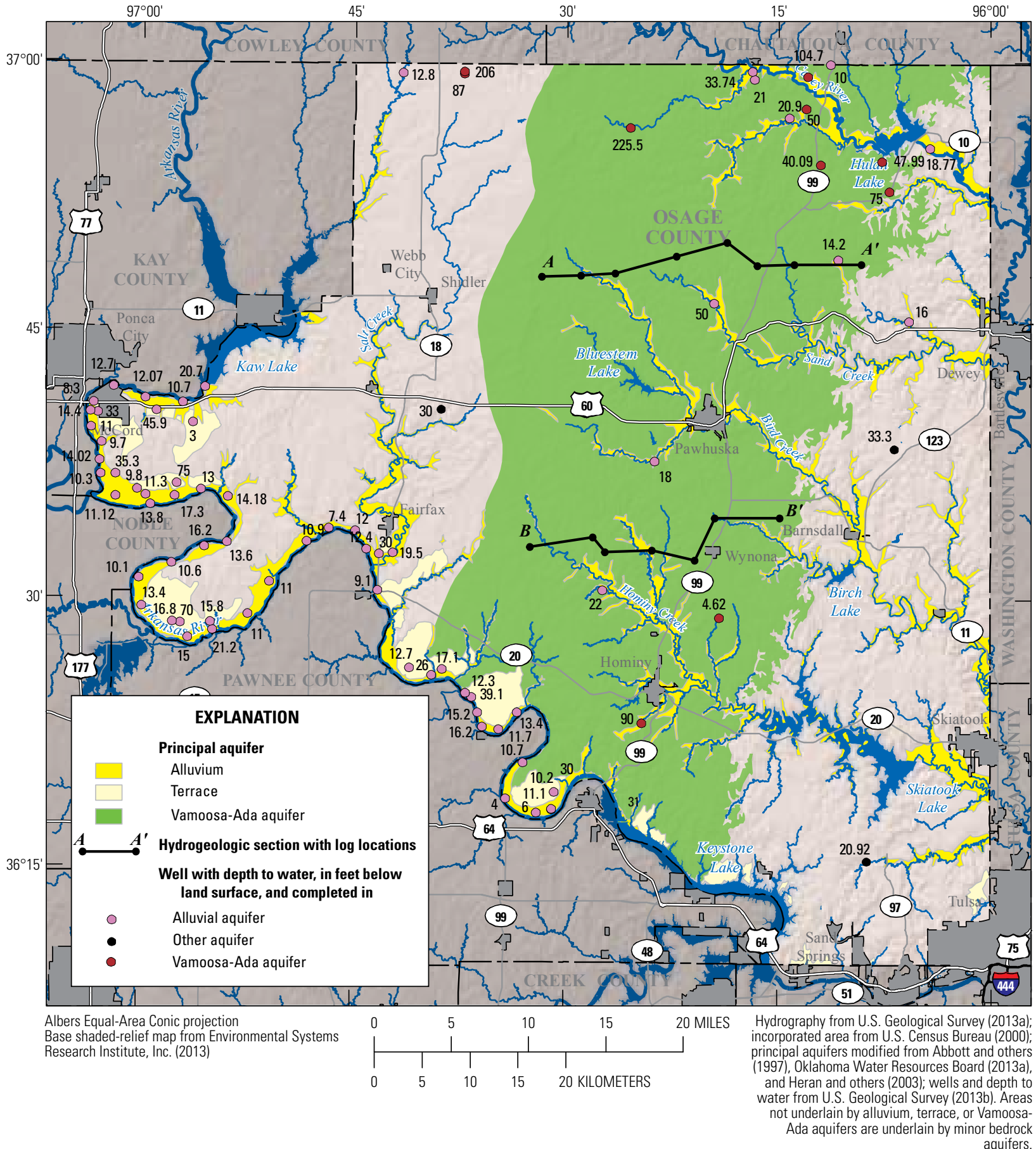

Figure 17. Principal aquifers and locations of 79 wells having depth-to-water measurements made by the U.S. Geological Survey in the Osage Nation, northeastern Oklahoma, as of 2012. 


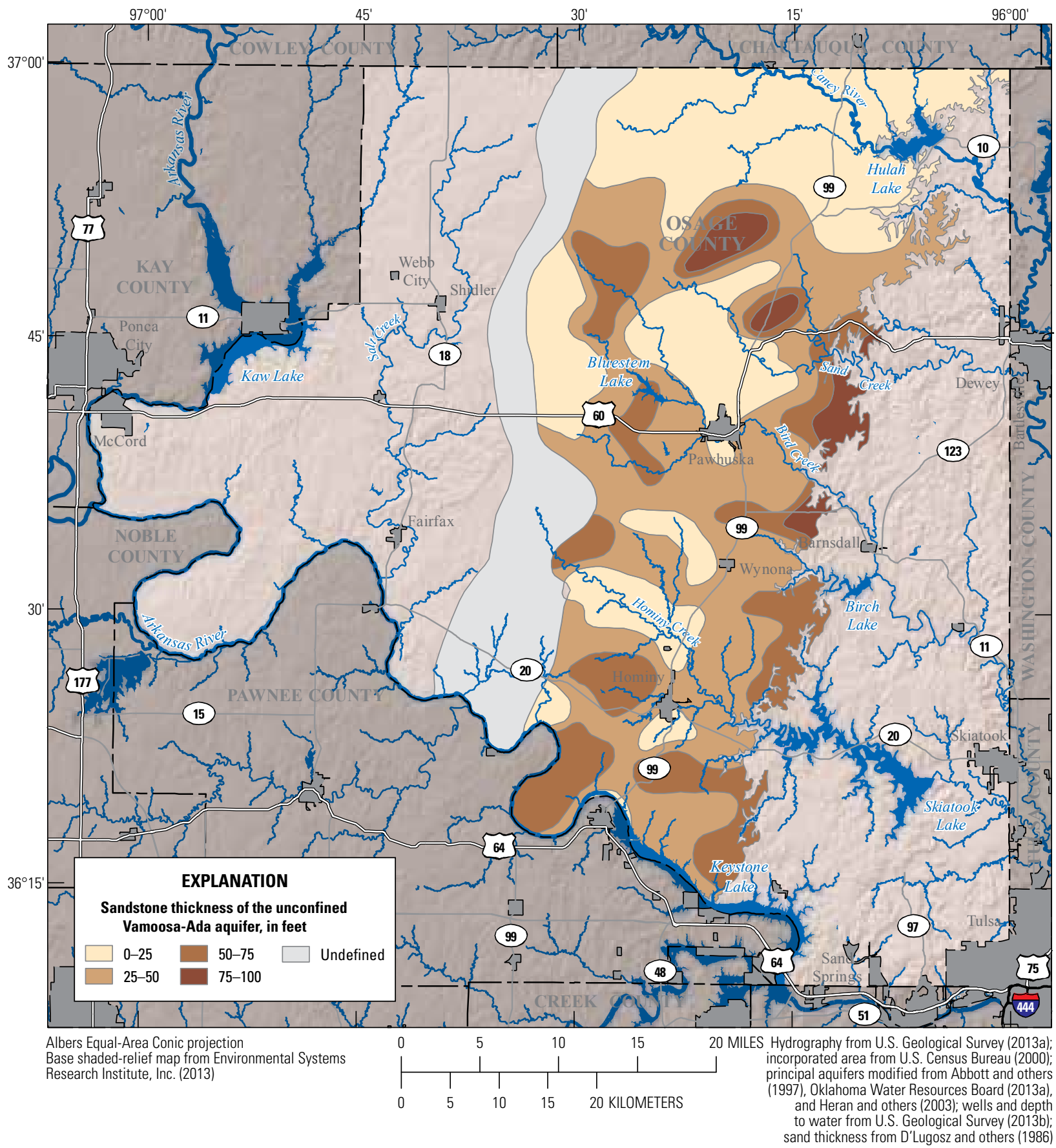

Figure 18. Sand thickness of the unconfined Vamoosa-Ada aquifer in the Osage Nation, northeastern Oklahoma. 


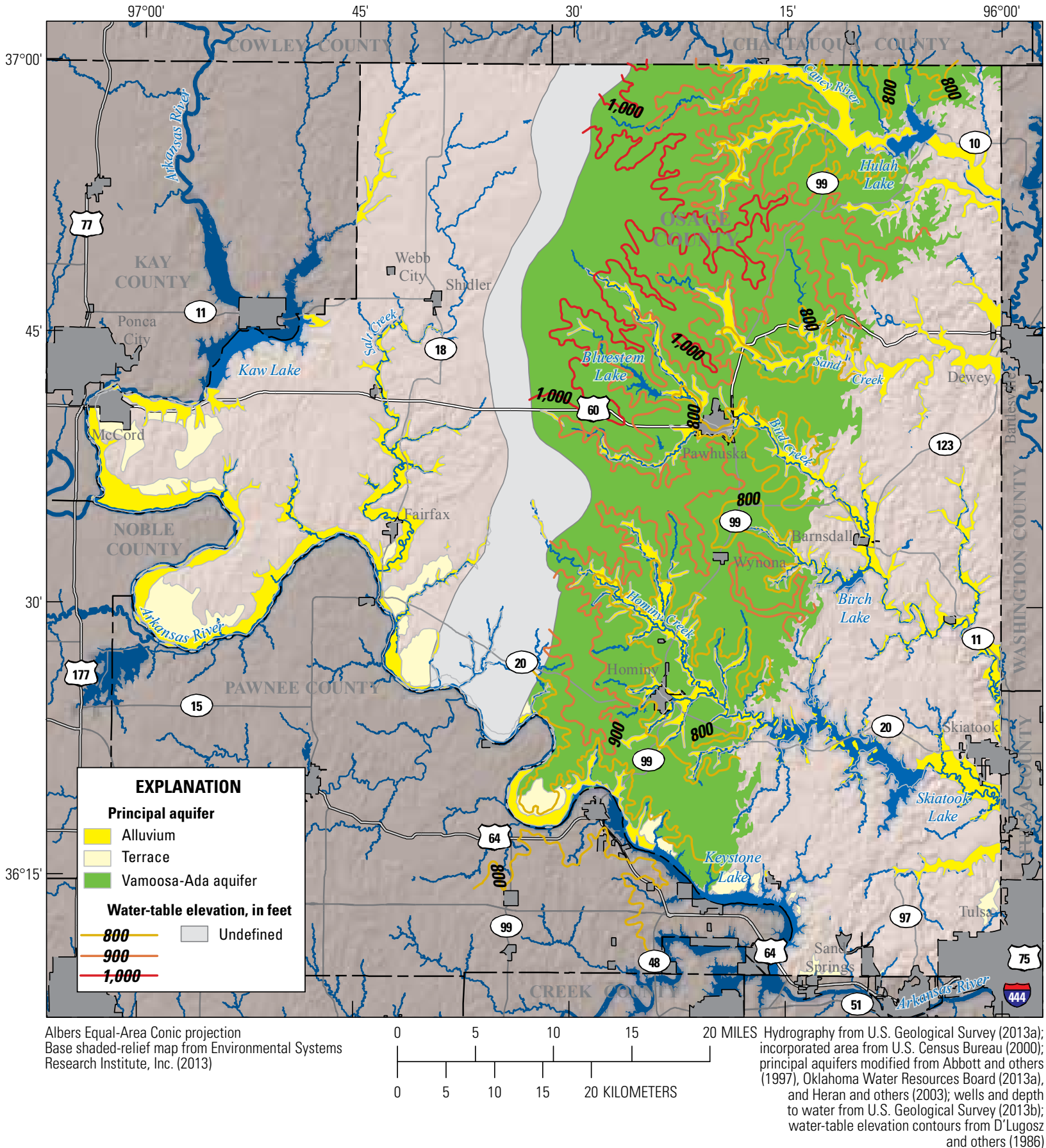

Figure 19. Water-table elevation in the unconfined Vamoosa-Ada aquifer in the Osage Nation, northeastern Oklahoma, as of 1975. 


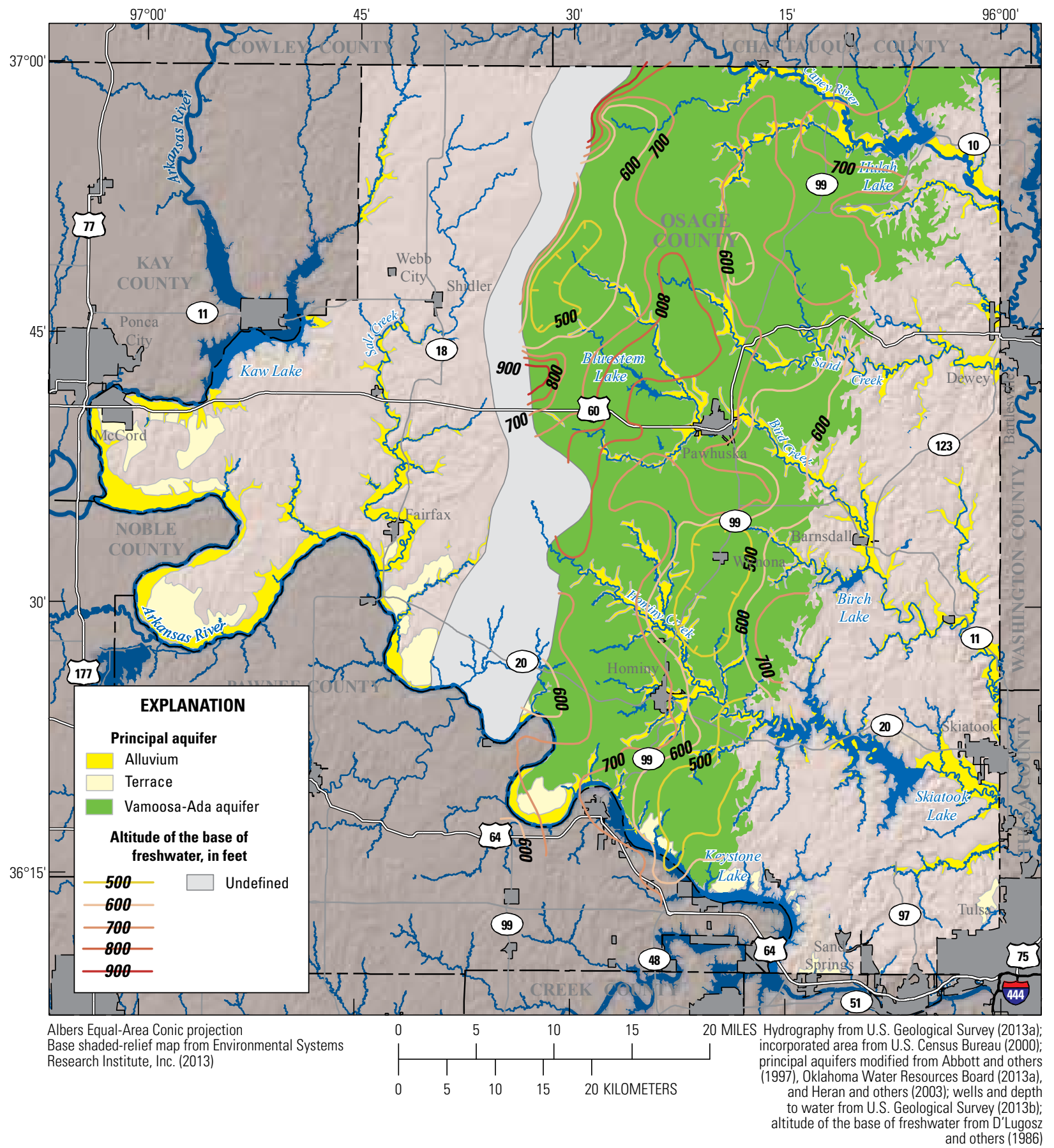

Figure 20. Altitude of the base of freshwater in the Vamoosa-Ada aquifer in the Osage Nation, northeastern Oklahoma, as of 1975. 


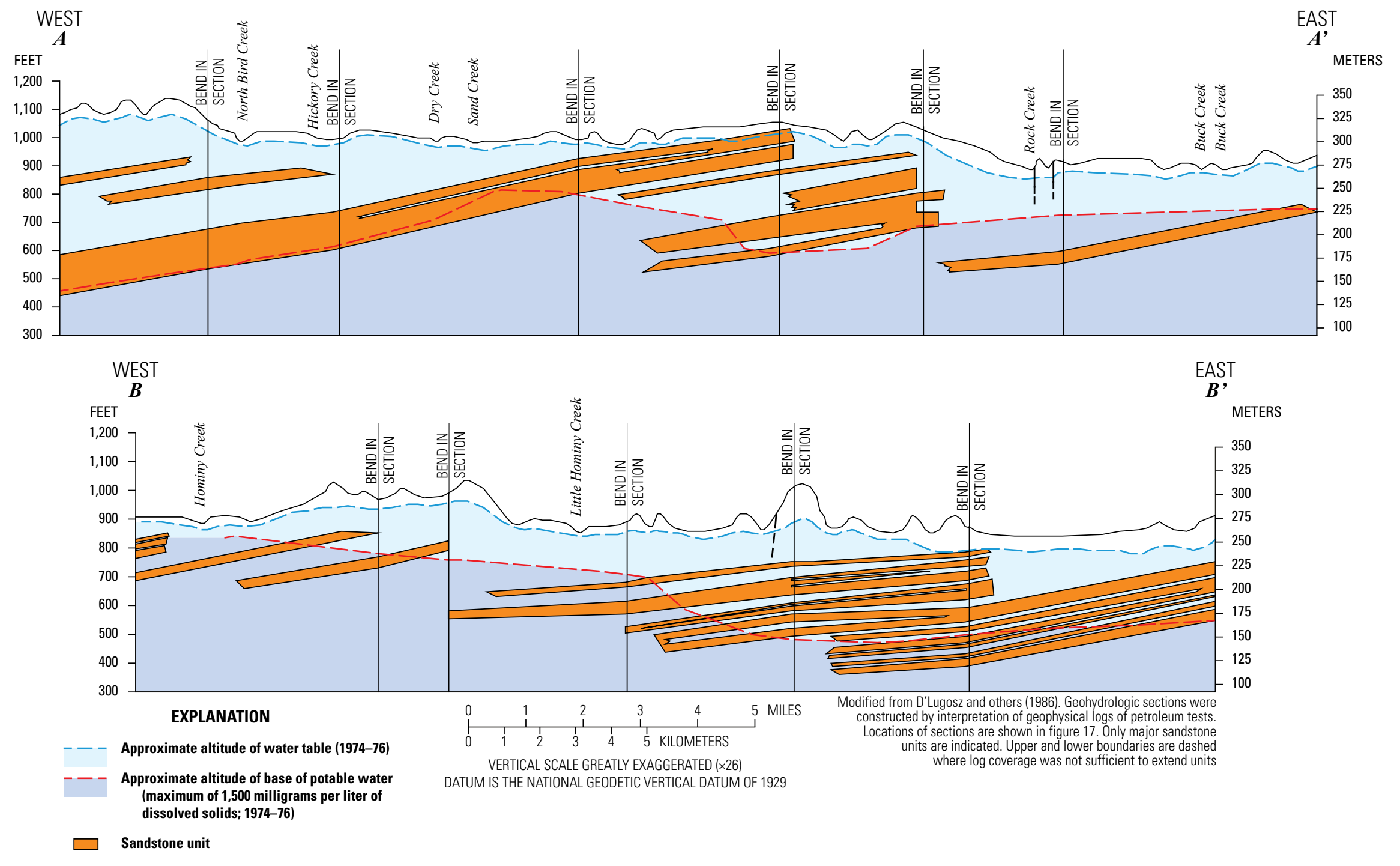

Figure 21. Sandstone layers and hydrogeologic boundaries in the Vamoosa-Ada aquifer in the Osage Nation, northeastern Oklahoma. 


\section{Groundwater Quality}

Groundwater-quality data collected from 88 wells completed in known or likely aquifers at known depths sampled by the USGS from 1972 through 1997 are summarized in this report (fig. 22). Concentrations of total dissolved solids, dissolved chloride, and total (rather than dissolved) phosphorus in groundwater samples collected from those wells are described in this report.

Because groundwater is in constant contact with minerals in rocks and sediments, it gradually dissolves those minerals and with time becomes saline, as described in Zouari and others (2011) and Cartwright and others (2012). Saline groundwater also can be related to connate water, seawater trapped between mineral grains at the time of deposition of sediments in marine environments (Bein and Dutton, 1993). All of the Osage Nation is underlain by brines containing large concentrations of sodium and chloride and total dissolved solids concentration as large as 200,000 mg/L (D'Lugosz and others, 1986; table 9).

Total dissolved solids concentrations were similar in water samples collected from freshwater supply wells completed in the alluvial, Vamoosa-Ada, and minor bedrock aquifers (fig. 23). Sampling of 103 temporary test holes in 2001 and 2002 in the alluvial aquifers adjoining the Arkansas River (Mashburn and others, 2003) produced a slightly larger range of total dissolved solids concentrations $(88-3,658 \mathrm{mg} / \mathrm{L})$ than were measured in the water samples collected from permanent wells described in this report. About 30 percent of water samples collected from 32 wells completed in the alluvial aquifers and 60 percent of the water samples collected from 54 wells completed in the Vamoosa-Ada aquifer contained total dissolved solids concentrations larger than the secondary drinking-water standard of $500 \mathrm{mg} / \mathrm{L}$ (fig. 23).

Chloride, a component of total dissolved solids, is a conservative element in hydrologic systems that can indicate sources and movement of groundwater, such as upward discharge of saline groundwater to springs and streams, or the effects of disposal or leakage of brines brought to the land surface during petroleum and natural-gas extraction. Chloride concentrations were significantly greater in water samples collected from wells completed in the Vamoosa-Ada aquifer than in water samples collected from wells completed in alluvial aquifers in the Osage Nation (fig. 24). Chloride concentrations in the few water samples collected from wells completed in minor aquifers were not significantly different than those in water samples collected from wells completed in alluvial and the Vamoosa-Ada aquifers in the Osage Nation (fig. 24). Water sampled from wells completed in alluvial, the Vamoosa-Ada, and minor bedrock aquifers generally contained smaller concentrations of dissolved chloride than water samples collected at Hominy Creek near Hominy, Okla., and the Arkansas River at Ralston, Okla., stations (figs. 13 and 24). Groundwater samples collected from 32 wells completed in alluvial and terrace aquifers contained dissolved chloride concentrations similar to those in water samples collected from the Bitter Creek and Bird Creek at Avant, Okla., sites (figs. 13 and 24). General decreases in dissolved chloride concentration with larger streamflows at five surface-water sites in the Osage Nation indicate that base flow (derived from groundwater seepage) tended to contain larger dissolved chloride concentrations than were measured in runoff (associated with high flows) in those streams (fig. 14). Larger concentrations of dissolved chloride in base flow may have been caused by upward seepage of saline groundwater along stream channels, as commonly shown in groundwater-flow models (fig. 25), or by increased dissolved chloride concentration in local shallow groundwater near petroleum-gathering structures such as evaporation ponds, tank batteries, and leaking pipelines as was described near Skiatook Lake in Kharaka and Otton (2003). As no general geographic patterns of dissolved chloride concentration in groundwater samples collected in the Osage Nation are apparent (fig. 22), local effects, either from seepage of brines into shallow groundwater or from leaks and spills from petroleum and natural-gas extraction activities conducted near the land surface, may cause the substantial variations in dissolved chloride concentration in groundwater in the Osage Nation. 


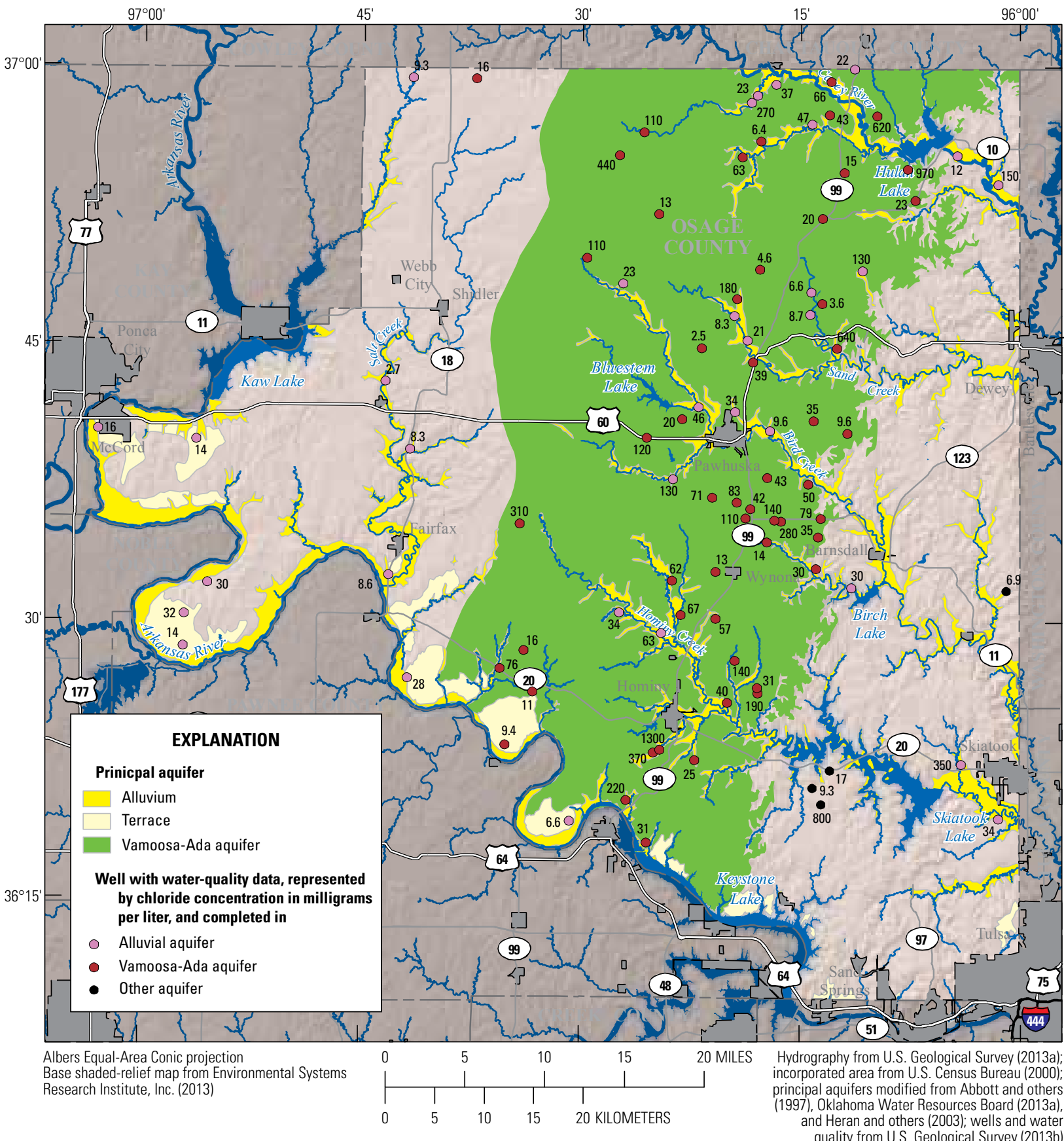

Figure 22. Locations of wells sampled for water quality in the Osage Nation, northeastern Oklahoma, 1972 through 1997. 
Table 9. Quality of 894 brine samples collected from petroleum and natural-gas wells in the Osage Nation, northeastern Oklahoma, 1939 through 1980.

[mg/L, milligrams per liter; source is U.S. Geological Survey (2013f)]

\begin{tabular}{lrrr}
\hline & \multicolumn{3}{c}{ Constituent } \\
\cline { 2 - 4 } \multicolumn{1}{c}{ Statistic } & $\begin{array}{c}\text { Total } \\
\text { dissolved } \\
\text { solids } \\
\text { (mg/L) }\end{array}$ & $\begin{array}{c}\text { Sodium } \\
\text { (mg/L) }^{1}\end{array}$ & $\begin{array}{c}\text { Chloride } \\
\text { (mg/L) }\end{array}$ \\
\hline Minimum & 1,270 & 1,530 & 450 \\
25th percentile & 79,400 & 37,600 & 48,800 \\
50th percentile (median) & 141,000 & 49,500 & 86,800 \\
75th percentile & 181,000 & 56,300 & 112,000 \\
Maximum & 290,000 & 87,600 & 179,000 \\
\hline
\end{tabular}

${ }^{1}$ Some samples were not analyzed for sodium concentrations.

Phosphorus concentration in groundwater typically is much less than in surface water because of sorption of phosphorus to metals in aquifer materials and relatively stable physical parameter values in groundwater as described in Drever (1988) and Morel and Hering (1993); however, longterm application of animal wastes and inorganic phosphate fertilizers to the land surface can increase phosphorus concentration in groundwater (Domalgalski and Johnson, 2012). In surface water, rapid changes in $\mathrm{pH}$ and oxidation state tend to cause cycles of release of phosphorus from streambed and lakebed sediments related to reduction and dissolution of iron and manganese minerals to which phosphorus commonly is sorbed (Morel and Hering, 1993). Runoff to streams and lakes during and immediately after precipitation also tends to carry small particles containing total phosphorus and dissolved phosphorus from animal wastes, other organic detritus, and soils at the land surface (Andrews and others, 2009; Esralew and others, 2012).

Total phosphorus concentrations measured in groundwater sampled in the Osage Nation were similar to dissolved phosphorus concentrations measured in surface-water samples collected from the Bird Creek at Avant, Okla., and the Arkansas River at Ralston, Okla., sites at smaller streamflows, indicating a probable relation between groundwater seeping to local streams at base-flow conditions and dissolved phosphorus concentration in those streams (figs. 15, 16, and 26), as described in Domalgalski and Johnson (2012). About 40 percent of the groundwater samples collected from alluvial aquifers in the Osage Nation contained phosphorus concentrations exceeding the standard for phosphorus in surface water set for Oklahoma Scenic Rivers of $0.037 \mathrm{mg} / \mathrm{L}$ (figs. 15 and 26), indicating that local groundwater may be affected by phosphorus seeping into alluvial materials from surface water and also may be a source of phosphorus to local streams through base flow.

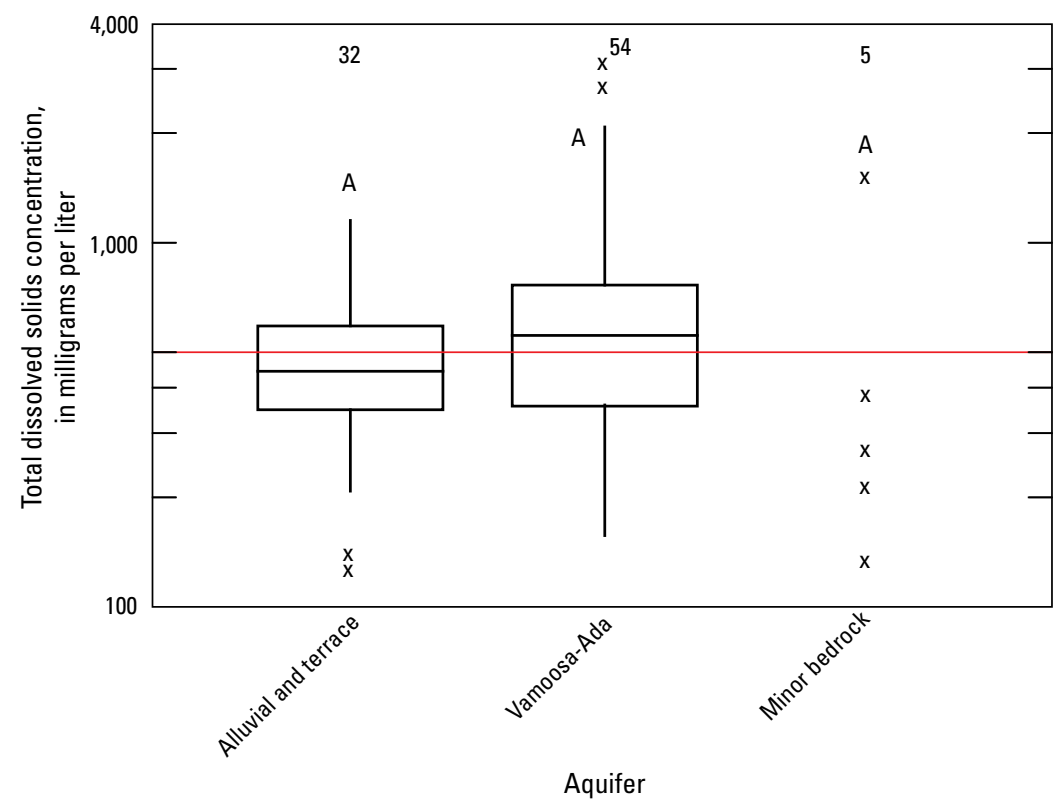

EXPLANATION

Number of values

Total dissolved solids concentration distributions with the same letter are not significantly different

( $p$-value greater than $\mathbf{0 . 0 5}$ for the

two-sided Wilcoxon rank-sum test)

Upper outside

Upper adjacent

Secondary drinking-water standard (U.S. Environmental Protection Agency, 2013b)

75th percentile

\begin{tabular}{l|l}
50 th percentile & Interquartile \\
(median)
\end{tabular} (median)

25th percentile range

Lower adjacent

$x \quad$ Lower outside

Figure 23. Total dissolved solids concentration by aquifer in the Osage Nation, northeastern Oklahoma, 1972 through 1997. 


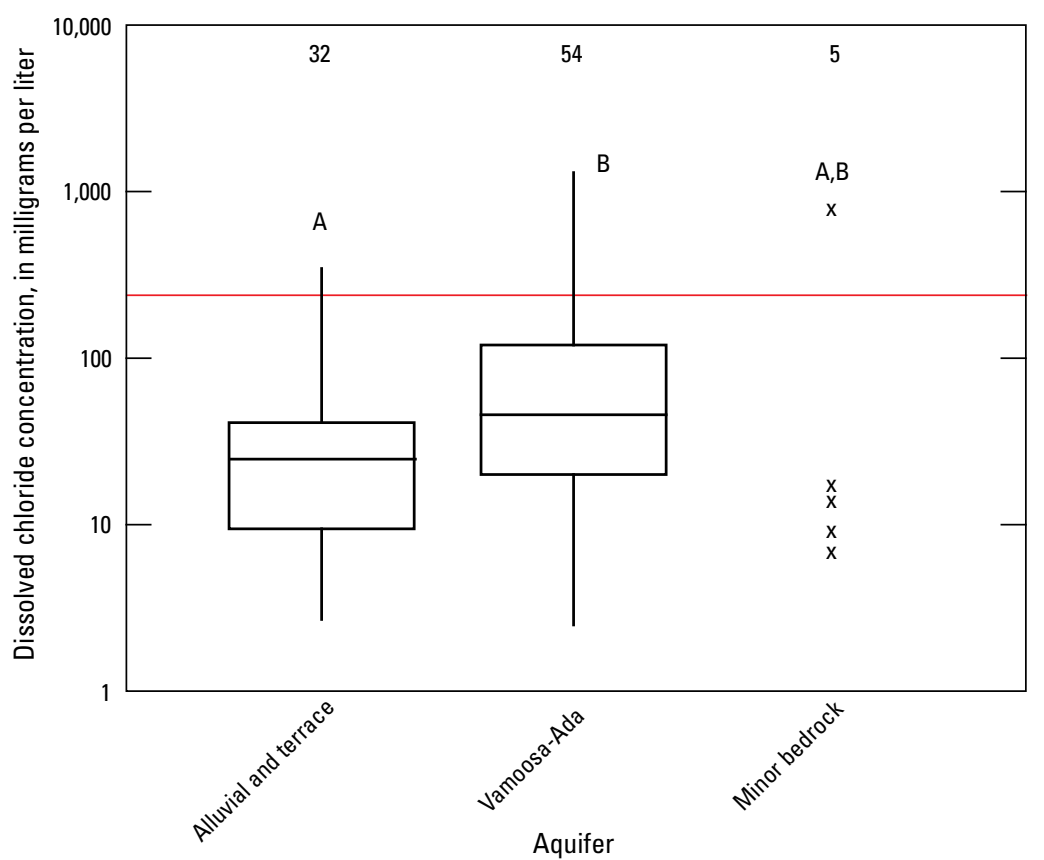

\section{EXPLANATION}

32 Number of values

A Dissolved chloride concentration distributions with the same letter are not significantly different ( $p$-value greater than $\mathbf{0 . 0 5}$ for the two-sided Wilcoxon rank-sum test)

x Upper outside Upper adjacent

- Secondary drinking-water standard (U.S. Environmental Protection Agency, 2013b)

75th percentile

50th percentile Interquartile (median)

25th percentil

Lower adjacent

$x \quad$ Lower outside

Figure 24. Dissolved chloride concentration in groundwater samples by aquifer in the Osage Nation, northeastern Oklahoma, 1972 through 1997.

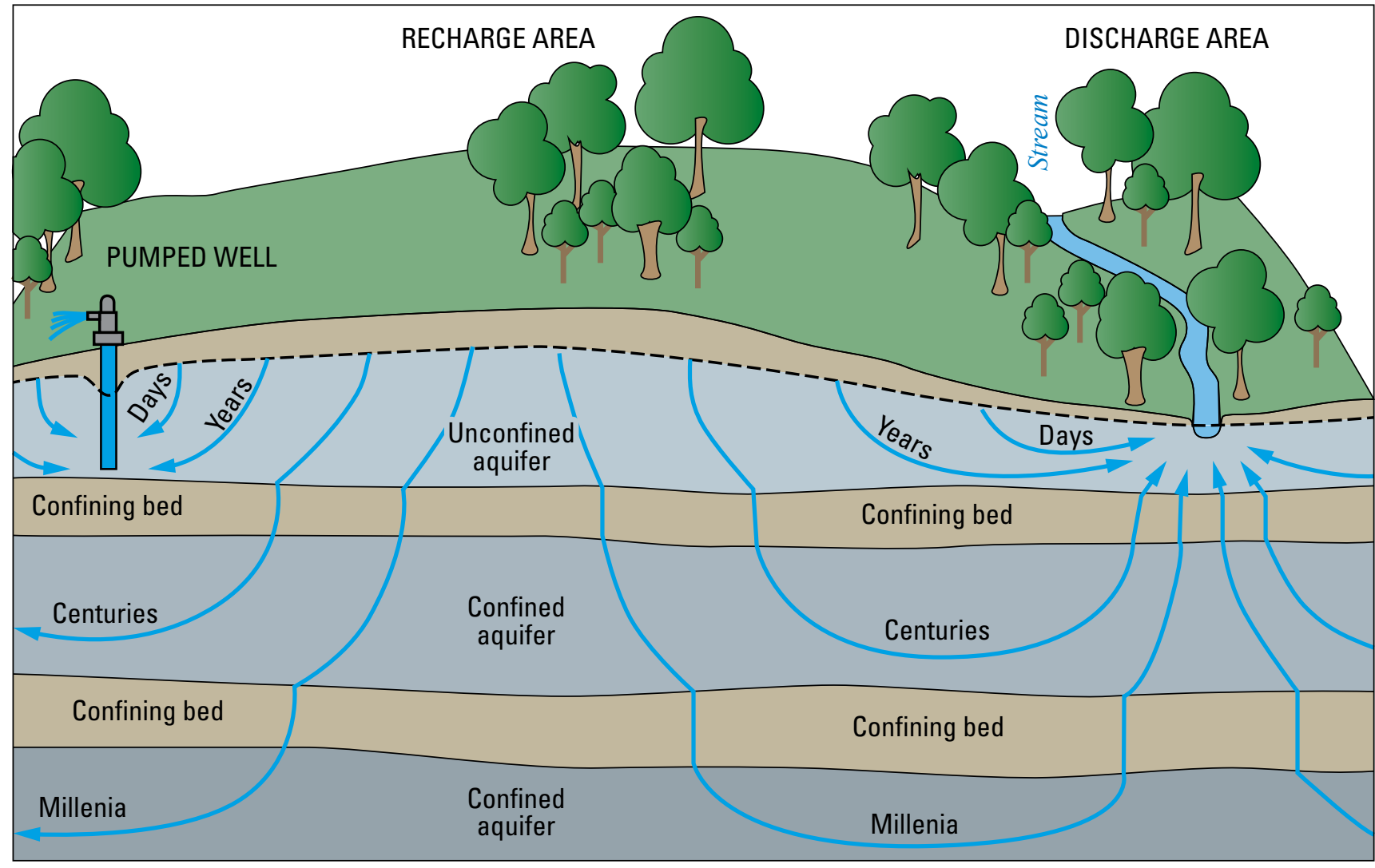

(U.S. Geological Survey, 2013g)

Figure 25. The general pattern of groundwater recharge and discharge to streams and wells. 

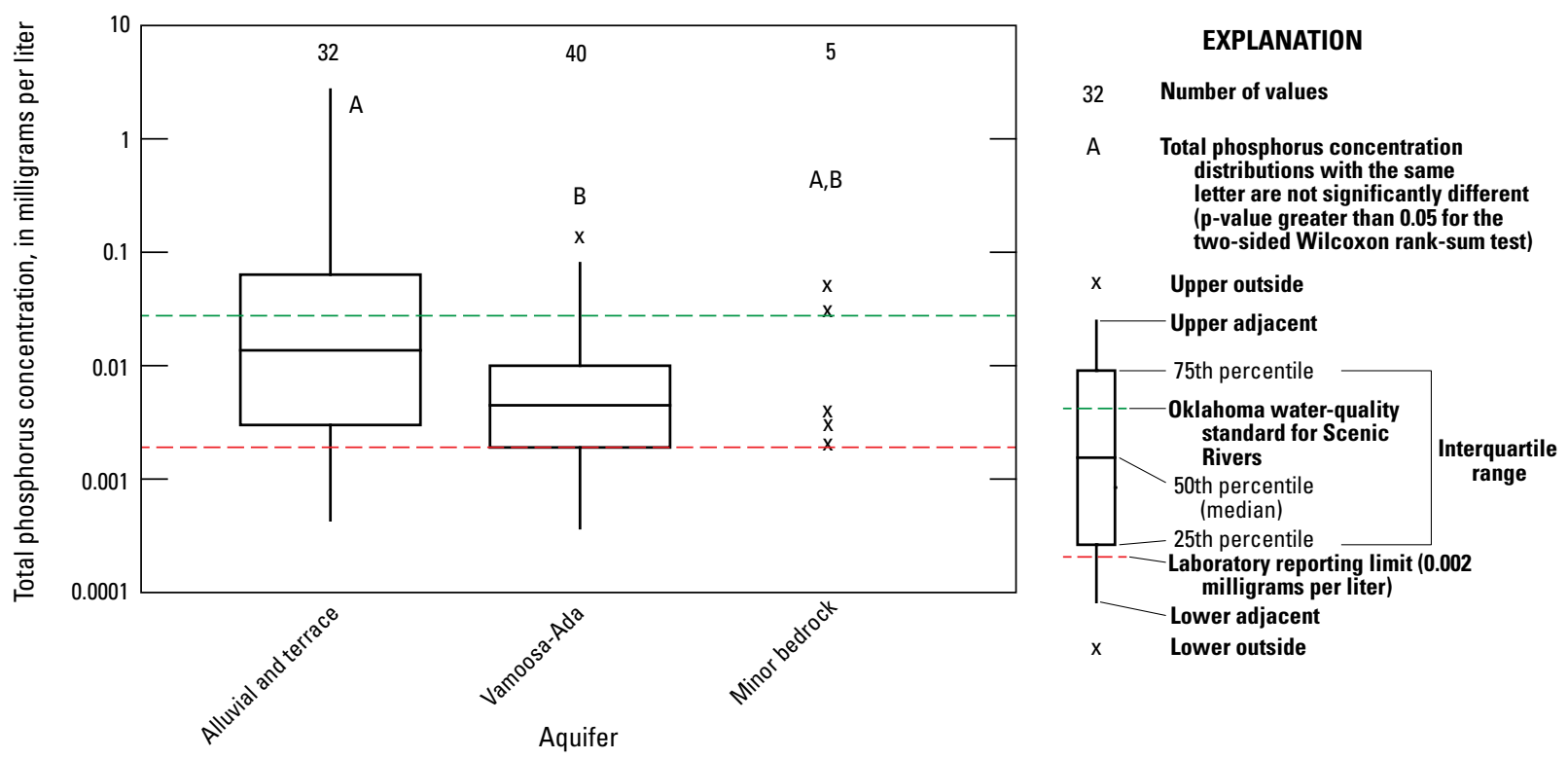

Figure 26. Total phosphorus concentration by aquifer in the Osage Nation, northeastern Oklahoma, 1972 through 1993.

\section{Estimated Water Use}

The primary water sources used in the Osage Nation are surface water withdrawn from Skiatook Lake and groundwater withdrawn from alluvial aquifers and the Vamoosa-Ada aquifer (fig. 1). Sources of data, coefficients, and other relevant information for each source type and purpose are described in the following sections.

\section{Public Supply Water Use}

Water withdrawn by public suppliers (cities, towns, rural water districts, and small communities) can be used for a variety of purposes, though typically it is used for domestic, commercial, and industrial purposes. The amounts of water withdrawn by public suppliers in areas like Osage County, where there are no large industries using water from public suppliers, are likely to be proportional to the number of customers served and thus are likely to change with human population (table 10). In 2010, about 96 percent of the water withdrawn by public suppliers in the Osage Nation was from surface-water sources (tables 11 and 12), with Skiatook Lake being the primary source of water for public water suppliers in the Osage Nation and for cities in or partly in adjoining counties, such as Sand Springs, Okla., and Sapulpa, Okla. (M. Goree, Oklahoma Water Resource Board, written commun., 2011). Estimated water withdrawals for public suppliers increased from none in 1890, when there were no known public water suppliers in the Osage Nation, to $14.3 \mathrm{Mgal} / \mathrm{d}$ in 2010 (fig. 27). A relatively large decrease in surface water withdrawn by public water suppliers in 1990 and a large increase of groundwater withdrawn by public water suppliers in 1995 in the Osage Nation may have been caused by limited water availability from the Skiatook Lake or the City of Tulsa and may also be related to the variable nature of data that is self-reported by water permit holders to the OWRB.

\section{Domestic Self-Supplied Water Use}

Osage Nation residents living outside of towns or service areas of rural water districts rely on private wells to provide domestic water. As previously described, estimates of domestic self-supplied water use were based on regressions of known water use in recent decades with population of the area back to 1890 and by using decreasing per capita wateruse coefficients dating back to 1890 . Domestic self-supplied water use in the Osage Nation from 1890 through 2010 was primarily groundwater withdrawn from domestic wells (tables 10-12). Before electricity was available in rural areas of the Osage Nation in the late 1800s through early 1900s, much of the water used for domestic purposes was likely to have come from hand-pumped wells or wells pumped by windmills at homesteads located at notable distances from streams or springs. Because of the gradual spread of public water suppliers in the Osage Nation through municipal suppliers and rural water districts (Oklahoma Water Resources Board, 1998), estimated domestic self-supplied water use did not increase substantially for much of the period from 1890 to 2010 , despite an increase in human population of a factor of about 15.8 during that period (fig. 27, tables 10-12). 
Table 10. Estimated human population and population water sources in the Osage Nation, northeastern Oklahoma, 1890 through 2010.

\begin{tabular}{|c|c|c|c|c|}
\hline Year & $\begin{array}{l}\text { Total human } \\
\text { population }\end{array}$ & $\begin{array}{l}\text { Population } \\
\text { using } \\
\text { publicly } \\
\text { supplied } \\
\text { surface } \\
\text { water }\end{array}$ & $\begin{array}{l}\text { Population } \\
\text { using } \\
\text { publicly } \\
\text { supplied } \\
\text { groundwater }\end{array}$ & $\begin{array}{l}\text { Population } \\
\text { using self- } \\
\text { supplied } \\
\text { groundwater }\end{array}$ \\
\hline 1890 & ${ }^{1} 3,000$ & ${ }^{3} 0$ & ${ }^{3} 0$ & 3,000 \\
\hline 1895 & ${ }^{2} 6,520$ & ${ }^{3} 0$ & ${ }^{3} 0$ & 6,520 \\
\hline 1900 & ${ }^{1} 10,050$ & ${ }^{3} 2,550$ & ${ }^{3} 420$ & 7,080 \\
\hline 1905 & ${ }^{2} 15,080$ & ${ }^{3} 4,050$ & ${ }^{3} 670$ & 10,360 \\
\hline 1910 & ${ }^{4} 20,100$ & ${ }^{3} 5,540$ & 3920 & 13,640 \\
\hline 1915 & 233,720 & ${ }^{3} 7,040$ & ${ }^{3} 1,170$ & 25,510 \\
\hline 1920 & ${ }^{4} 36,540$ & ${ }^{3} 8,540$ & ${ }^{3} 1,420$ & 26,580 \\
\hline 1925 & 244,420 & ${ }^{3} 10,030$ & ${ }^{3} 1,670$ & 30,240 \\
\hline 1930 & ${ }^{4} 47,330$ & ${ }^{3} 11,430$ & ${ }^{3} 1,920$ & 33,980 \\
\hline 1935 & 237,280 & ${ }^{3} 13,020$ & ${ }^{3} 2,170$ & 22,090 \\
\hline 1940 & ${ }^{4} 33,070$ & ${ }^{3} 14,520$ & ${ }^{3} 2,420$ & 16,130 \\
\hline 1945 & 236,590 & ${ }^{3} 16,020$ & ${ }^{3} 2,670$ & 17,900 \\
\hline 1950 & ${ }^{4} 40,110$ & ${ }^{3} 17,510$ & ${ }^{3} 2,920$ & 19,680 \\
\hline 1955 & ${ }^{2} 36,280$ & ${ }^{3} 19,010$ & ${ }^{3} 3,170$ & 14,100 \\
\hline 1960 & ${ }^{4} 32,440$ & ${ }^{3} 20,500$ & ${ }^{3} 3,420$ & 8,520 \\
\hline 1965 & 231,100 & ${ }^{3} 22,000$ & ${ }^{3} 3,670$ & 5,430 \\
\hline 1970 & ${ }^{4} 29,750$ & ${ }^{3} 23,500$ & ${ }^{3} 3,920$ & 2,330 \\
\hline 1975 & 532,900 & ${ }^{3} 25,000$ & ${ }^{3} 4,170$ & 3,730 \\
\hline 1980 & ${ }^{4} 41,640$ & ${ }^{3} 26,490$ & ${ }^{3} 4,420$ & 10,730 \\
\hline 1985 & 641,500 & ${ }^{7} 29,600$ & ${ }^{75}, 260$ & ${ }^{7} 6,640$ \\
\hline 1990 & ${ }^{7} 41,640$ & ${ }^{7} 30,360$ & ${ }^{7} 6,690$ & 74,590 \\
\hline 1995 & ${ }^{7} 42,580$ & ${ }^{7} 29,430$ & ${ }^{7} 6,260$ & ${ }^{7} 6,890$ \\
\hline 2000 & 744,440 & 730,620 & 75,620 & ${ }^{7} 8,200$ \\
\hline 2005 & 845,330 & 833,930 & ${ }^{8} 4,640$ & ${ }^{8} 6,760$ \\
\hline 2010 & 47,470 & 32,940 & 7,440 & 7,090 \\
\hline
\end{tabular}

${ }^{1}$ Estimated from changes in statewide census numbers in Bureau of the Census (2002).

${ }^{2}$ Estimated by interpolation between decennial censuses.

${ }^{3}$ Estimated from linear regression of total population served by public water supplies and approximate 6 to 1 ratio of population served by surface water to population served by groundwater.

${ }^{4}$ Forstall (1995).

${ }^{5}$ Bureau of the Census (1982).

${ }^{6}$ Bureau of the Census (1992).

${ }^{7}$ U.S. Geological Survey (2013c).

${ }^{8}$ Tortorelli (2009).

\section{Industrial Self-Supplied Water Use}

Industrial self-supplied water-use data are available by county from the USGS AWUDS database spanning the period 1985-2010 (U.S. Geological Survey, 2013d). Those data and linear interpolation of industrial self-supplied water use in the Osage Nation, based on an assumption of zero use for this purpose in the late 19th century, indicated that industrial self-supplied use of surface water and groundwater in the Osage Nation has been a relatively small component of total water use, generally averaging a few hundred thousand gallons per day for the period 1915 through 2010 (fig. 27, tables 11 and 12). The primary industry of this mostly rural area up to the present (2014) has consisted of drilling for and extraction of petroleum and natural gas. Water used for those activities is considered by the USGS to be related to "mining activities" and, as such, is included in that water-use category in this report (Tortorelli, 2009).

\section{Irrigation Water Use}

Irrigation water use generally increased in Oklahoma after the advent of center-pivot irrigation in the mid-1940s (Oklahoma Historical Society, 2013). The greatest use of early center-pivot irrigation equipment generally was in the drier western half of the State, particularly in the panhandle (Oklahoma Historical Society, 2013). In the Osage Nation, irrigation water use was not reported until 1954 (Bureau of the Census, 1956). Estimated irrigation water use has averaged between about 0.15 and $0.50 \mathrm{Mgal} / \mathrm{d}$ since that time, with the majority of estimated water withdrawals for this purpose being from surface water (fig. 27, tables 11 and 12).

\section{Livestock Water Use}

Livestock water use was estimated from numbers of livestock reported in or estimated from agricultural censuses and per-head estimates of daily water use by major types of livestock. Because of the rural nature of the Osage Nation and relatively large numbers of livestock compared to numbers of humans, water use for livestock has been a substantial part of water use in this area from 1890 through 2010 , only being exceeded for much of that period by water used by public suppliers (fig. 27, tables 11 and 12). After a period of erratic livestock census counts and related estimated water use from 1890 through 1930 - perhaps caused by poor surveying methods, adjustments by ranchers to the climate of Oklahoma, and the agricultural depression of the 1920s through the 1930s - water use for livestock slowly increased through 2010 (fig. 27, tables 11 and 12), averaging $1.69 \mathrm{Mgal} / \mathrm{d}$ from 1990 through 2010. 
Table 11. Estimated fresh surface-water use, by purpose, in the Osage Nation, northeastern Oklahoma, 1890 through 2010.

[Water use in million gallons per day]

\begin{tabular}{|c|c|c|c|c|c|c|c|}
\hline Year & $\begin{array}{l}\text { Public } \\
\text { supply }\end{array}$ & $\begin{array}{c}\text { Self-supplied } \\
\text { domestic }\end{array}$ & $\begin{array}{l}\text { Self-supplied } \\
\text { industrial }\end{array}$ & Irrigation & Livestock & Aquaculture & Total \\
\hline 1890 & 0.00 & 0.00 & 0.00 & 0.00 & 0.75 & 0.00 & 0.75 \\
\hline 1895 & 0.00 & 0.00 & 0.00 & 0.00 & 1.38 & 0.00 & 1.38 \\
\hline 1900 & 0.98 & 0.00 & 0.01 & 0.00 & 0.63 & 0.00 & 1.62 \\
\hline 1905 & 1.58 & 0.00 & 0.02 & 0.00 & 0.80 & 0.00 & 2.40 \\
\hline 1910 & 2.18 & 0.00 & 0.03 & 0.00 & 0.98 & 0.00 & 3.19 \\
\hline 1915 & 2.78 & 0.00 & 0.06 & 0.00 & 1.06 & 0.00 & 3.90 \\
\hline 1920 & 3.38 & 0.00 & 0.06 & 0.00 & 1.12 & 0.00 & 4.56 \\
\hline 1925 & 3.97 & 0.00 & 0.07 & 0.00 & 0.84 & 0.00 & 4.90 \\
\hline 1930 & 4.53 & 0.00 & 0.09 & 0.00 & 0.85 & 0.00 & 5.47 \\
\hline 1935 & 5.17 & 0.00 & 0.07 & 0.00 & 1.21 & 0.00 & 6.45 \\
\hline 1940 & 5.77 & 0.00 & 0.06 & 0.00 & 1.25 & 0.00 & 7.08 \\
\hline 1945 & 6.37 & 0.00 & 0.06 & 0.00 & 1.33 & 0.00 & 7.76 \\
\hline 1950 & 6.96 & 0.00 & 0.07 & 0.00 & 1.21 & 0.00 & 8.24 \\
\hline 1955 & 7.56 & 0.00 & 0.06 & 0.13 & 1.28 & 0.00 & 9.03 \\
\hline 1960 & 8.16 & 0.00 & 0.06 & 0.23 & 1.22 & 0.00 & 9.67 \\
\hline 1965 & 8.76 & 0.00 & 0.05 & 0.28 & 1.48 & 0.00 & 10.57 \\
\hline 1970 & 9.36 & 0.00 & 0.05 & 0.40 & 1.48 & 0.00 & 11.29 \\
\hline 1975 & 9.96 & 0.00 & 0.06 & 0.30 & 1.52 & 0.00 & 11.84 \\
\hline 1980 & 10.56 & 0.00 & 0.07 & 0.24 & 1.39 & 0.00 & 12.26 \\
\hline 1985 & ${ }^{1} 10.21$ & ${ }^{1} 0.05$ & ${ }^{1} 0.03$ & ${ }^{1} 0.18$ & 1.20 & ${ }^{1} 0.00$ & 11.67 \\
\hline 1990 & ${ }^{18} 8.93$ & ${ }^{1} 0.00$ & ${ }^{1} 0.01$ & ${ }^{1} 0.19$ & 1.39 & ${ }^{1} 0.00$ & 10.52 \\
\hline 1995 & ${ }^{1} 13.09$ & ${ }^{1} 0.00$ & ${ }^{1} 0.01$ & ${ }^{1} 0.09$ & 1.60 & ${ }^{1} 0.00$ & 14.79 \\
\hline 2000 & ${ }^{1} 13.98$ & ${ }^{1} 0.00$ & ${ }^{1} 0.00$ & ${ }^{1} 0.17$ & 1.56 & ${ }^{1} 0.00$ & 15.71 \\
\hline 2005 & ${ }^{2} 13.90$ & ${ }^{1} 0.00$ & ${ }^{1} 0.13$ & ${ }^{1} 0.11$ & 1.51 & ${ }^{1} 0.00$ & 15.65 \\
\hline 2010 & 13.77 & 0.00 & 0.16 & 0.20 & 1.55 & 0.51 & 16.19 \\
\hline
\end{tabular}

${ }^{1}$ U.S. Geological Survey (2013c).

${ }^{2}$ Tortorelli (2009).

\section{Aquaculture Water Use}

From 1985 through 2005, no water use for aquaculture was estimated to have occurred in the Osage Nation (tables 11 and 12). That estimation of no water use for aquaculture was extrapolated back to 1890 (fig. 27, tables 11 and 12). For 2010 , estimation of $0.51 \mathrm{Mgal} / \mathrm{d}$ of surface-water use and $0.03 \mathrm{Mgal} / \mathrm{d}$ of groundwater use (not shown in fig. 27) for aquaculture in the Osage Nation was based on data collected for the 2007 Census of Agriculture, some of which were unpublished (J. Lovelace, U.S. Geological Survey, written commun., 2013).

\section{Mining Water Use}

No freshwater withdrawals were recorded for mining purposes in the Osage Nation from 1985 through 2010 (U.S. Geological Survey, 2013d; tables 11 and 12). Extraction of petroleum and natural gas, the primary mining activity in this area, includes extraction of saline groundwater, much of which is reinjected into the petroleum-producing zones, which are stratigraphically below the bedrock aquifers in this area, to enhance petroleum extraction in the process known as water flooding (Collins, 1974; K. Murray, Oklahoma Geological Survey, written commun., 2014). Use of hydraulic fracturing, also known as fracking, to extract remaining petroleum and natural gas from existing fields and previously undeveloped shale units may have increased saline-groundwater reinjection in the heavily developed Burbank Oil Field (fig. 12) in the Osage Nation in recent years (Murray, 2013). The amount of saline groundwater reinjected in the Burbank Oil Field, which is one of several petroleum and naturalgas producing fields in the Osage Nation, was considerably larger than the amount of freshwater estimated to have been withdrawn for all other purposes in the Osage Nation during 1950-2012 (tables 11-13). Additional amounts of produced saline groundwater probably are reinjected in other producing fields in the Osage Nation (fig. 12), but data were not available from those fields when this report was written. Freshwater also may be used for fracking in this area, but no 
Table 12. Estimated fresh groundwater use, by purpose, in the Osage Nation, northeastern Oklahoma, 1890 through 2010.

[Water use in million gallons per day]

\begin{tabular}{cccccccc}
\hline Year & $\begin{array}{c}\text { Public } \\
\text { supply }\end{array}$ & $\begin{array}{c}\text { Self-supplied } \\
\text { domestic }\end{array}$ & $\begin{array}{c}\text { Self-supplied } \\
\text { industrial }\end{array}$ & Irrigation & Livestock & Aquaculture & Total \\
\hline 1890 & 0.00 & 0.05 & 0.00 & 0.00 & 0.08 & 0.00 & 0.13 \\
1895 & 0.00 & 0.10 & 0.00 & 0.00 & 0.15 & 0.00 & 0.25 \\
1900 & 0.00 & 0.11 & 0.01 & 0.00 & 0.07 & 0.00 & 0.19 \\
1905 & 0.01 & 0.16 & 0.06 & 0.00 & 0.09 & 0.00 & 0.32 \\
1910 & 0.03 & 0.48 & 0.11 & 0.00 & 0.11 & 0.00 & 0.73 \\
1915 & 0.04 & 0.89 & 0.24 & 0.00 & 0.12 & 0.00 & 1.29 \\
1920 & 0.05 & 0.93 & 0.27 & 0.00 & 0.12 & 0.00 & 1.37 \\
1925 & 0.06 & 1.06 & 0.32 & 0.00 & 0.09 & 0.00 & 1.53 \\
1930 & 0.08 & 1.19 & 0.38 & 0.00 & 0.09 & 0.00 & 1.74 \\
1935 & 0.09 & 0.77 & 0.28 & 0.00 & 0.13 & 0.00 & 1.27 \\
1940 & 0.10 & 0.97 & 0.24 & 0.00 & 0.14 & 0.00 & 1.45 \\
1945 & 0.11 & 1.07 & 0.27 & 0.00 & 0.15 & 0.00 & 1.60 \\
1950 & 0.13 & 1.18 & 0.31 & 0.00 & 0.13 & 0.00 & 1.75 \\
1955 & 0.14 & 0.85 & 0.27 & 0.03 & 0.14 & 0.00 & 1.43 \\
1960 & 0.15 & 0.51 & 0.23 & 0.06 & 0.14 & 0.00 & 1.09 \\
1965 & 0.16 & 0.33 & 0.22 & 0.07 & 0.16 & 0.00 & 0.94 \\
1970 & 0.18 & 0.20 & 0.20 & 0.11 & 0.16 & 0.00 & 0.85 \\
1975 & 0.19 & 0.32 & 0.23 & 0.08 & 0.17 & 0.00 & 0.99 \\
1980 & 0.20 & 0.91 & 0.32 & 0.06 & 0.15 & 0.00 & 1.64 \\
1985 & 10.31 & 0.56 & 1.03 & 10.07 & 0.13 & ${ }^{1} 0.00$ & 2.10 \\
1990 & 10.28 & 10.39 & 10.04 & 0.06 & 0.15 & 10.00 & 0.92 \\
1995 & 1.62 & 10.58 & 10.00 & 10.03 & 0.18 & 10.00 & 2.41 \\
2000 & 10.11 & 10.70 & 10.36 & 10.01 & 0.17 & 10.00 & 1.35 \\
2005 & 20.12 & 10.57 & 10.41 & 0.00 & 0.17 & 10.00 & 1.37 \\
2010 & 0.53 & 0.60 & 1.05 & 0.01 & 0.17 & 0.03 & 2.39 \\
\hline
\end{tabular}

${ }^{1}$ U.S. Geological Survey (2013b).

${ }^{2}$ Tortorelli (2009).

data for such water use were available when this report was being written.

\section{Thermoelectric Water Use}

As there were no known thermoelectric power plants generating electricity in the Osage Nation from 1985 through 2010, no water was estimated to have been used for generation of electrical power in this area during that period (U.S. Geological Survey, 2013d). Because no information related to possible previous thermoelectric powerplants operating in the Osage Nation was available, no water was assumed to have been used for generation of electrical power for the preceding period of 1890-1980.

\section{Water Use for All Purposes}

Predominant fresh surface-water uses and fresh groundwater uses in 2010 were for public water supply, livestock, and industrial self-supplied purposes. From 1890 through 2010, estimated freshwater use in the Osage Nation gradually increased from less than $1 \mathrm{Mgal} / \mathrm{d}$ to nearly $19 \mathrm{Mgal} / \mathrm{d}$ (fig. 28, tables 11 and 12). Total fresh surface-water withdrawals (use) and fresh groundwater withdrawals in the Osage Nation were estimated to have increased from 0.75 to $16.19 \mathrm{Mgal} / \mathrm{d}$ and from 0.13 to $2.39 \mathrm{Mgal} / \mathrm{d}$, respectively, from 1890 to 2010. Much of that increase in freshwater use can be attributed to increase in human population of the area, increased per capita water use by humans, and developments in infrastructure and technology that increased water withdrawals for industry and irrigation. Increased human population and development of the Tulsa metropolitan area, including cities such as Sapulpa, Okla., and Sand Springs, Okla., are likely to increase demand for freshwater in the Osage Nation, from both lakes and groundwater in the future. 


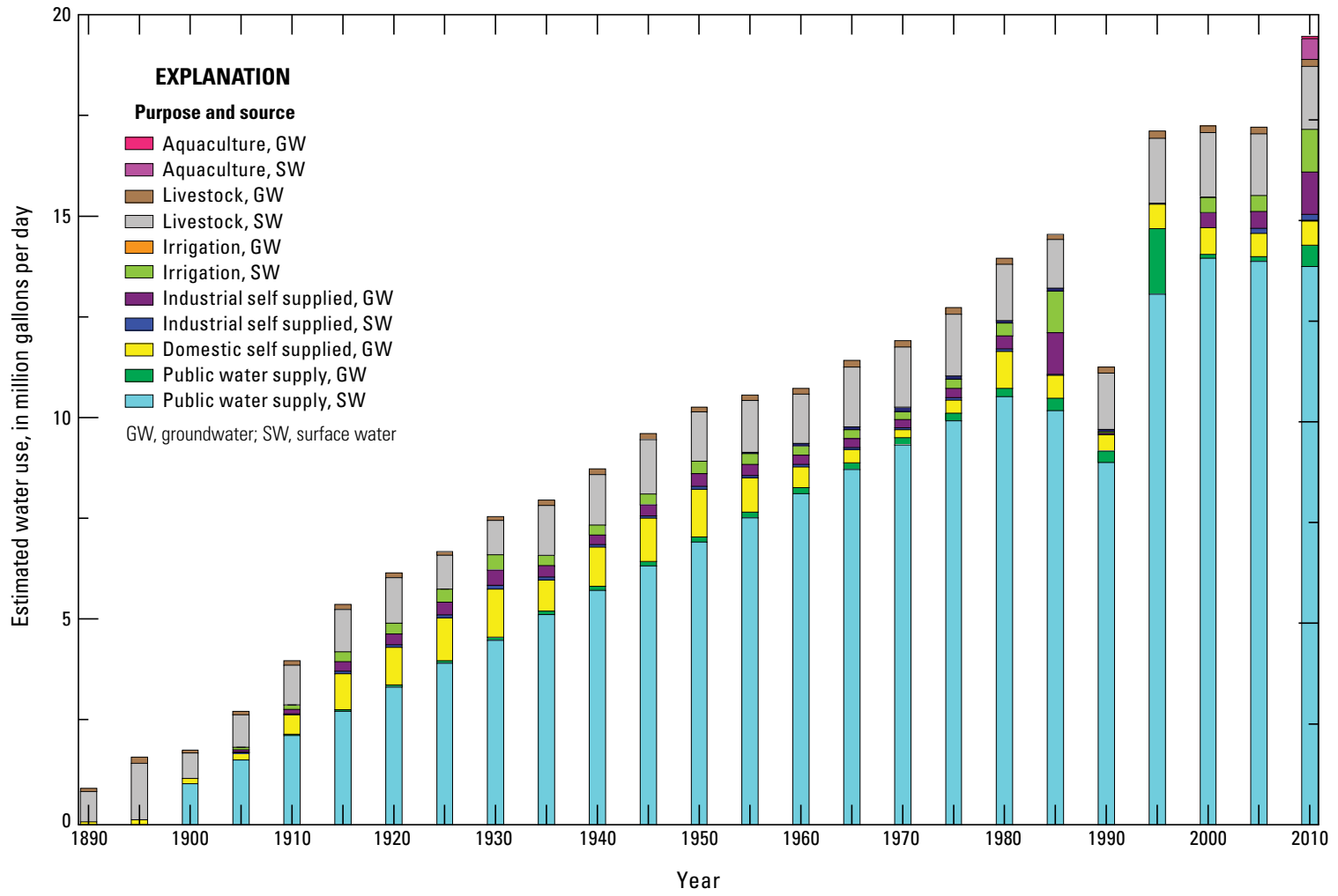

Figure 27. Estimated freshwater use, by purpose and source, in the Osage Nation, northeastern Oklahoma, 1890 through 2010.

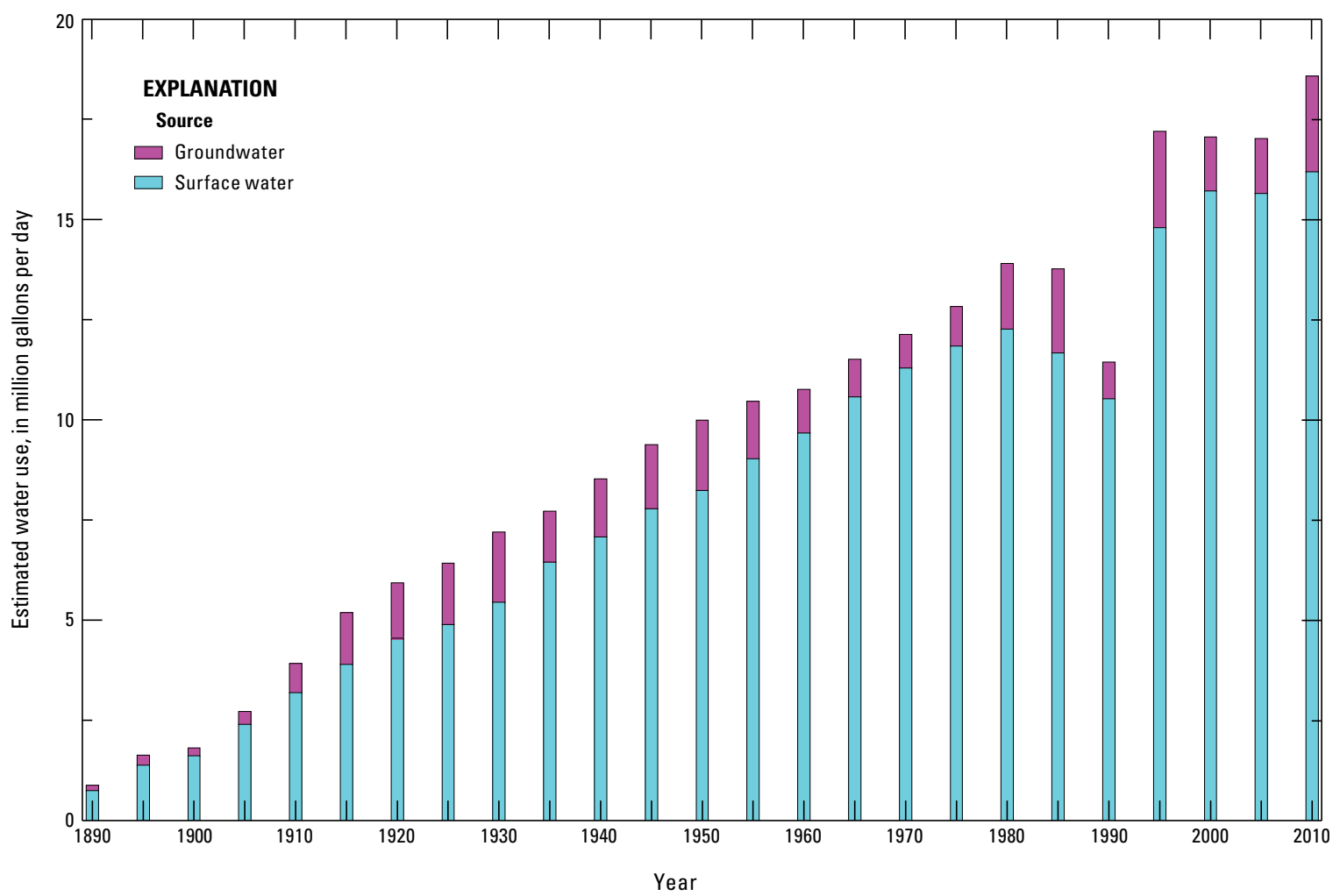

Figure 28. Estimated fresh surface-water and groundwater use by source in the Osage Nation, northeastern Oklahoma, 1890 through 2010. 
Saline-groundwater use, as measured by reinjection of saline water after withdrawal during petroleum and naturalgas extraction, was many times larger than all freshwater use in the Osage Nation, as estimated for one petroleum field (Burbank Oil Field) in the Osage Nation (tables 11-13). Increases in saline-groundwater use during the 2000s (table 13) may be related to a combination of increased use of fracking in horizontal wells to withdraw remaining petroleum and natural gas and to a nearly fourfold increase in petroleum prices during that period (McElroy and $\mathrm{Lu}$, 2013; U.S. Energy Information Administration, 2013). With ongoing improvements in desalinization technology, salinewater resources may be used in increasing amounts for other purposes in addition to reinjection in petroleum-producing strata or deep disposal wells (Osborn and others, 2013).

\section{Water-Resource Estimates}

The Osage Nation is bounded on the west and southwest for 123 miles by the Arkansas River. At the Arkansas River near Ralston, Okla., streamflow-gaging station, annual mean streamflows ranged from 1,121 to $16,810 \mathrm{ft}^{3} / \mathrm{s}(812,123$ to $12,407,788 \mathrm{acre}-\mathrm{ft} / \mathrm{yr}$ or 724 to $10,900 \mathrm{Mgal} / \mathrm{d}$ ) from 1977 through 2012 (U.S. Geological Survey, 2013a). Five lakes operated by the U.S. Army Corps of Engineers and other smaller lakes in the Osage Nation contain conservation storage of about 3,781,000 acre-ft $(1,230,000$ million gallons [Mgal]) of water (Shields, 1993). The alluvial aquifers adjacent to the Arkansas River have been estimated to contain about 4,116,000 acre- $\mathrm{ft}(1,340,000 \mathrm{Mgal})$ of water, terrace aquifers were estimated to contain about 1,250,000 acre-ft

Table 13. Estimated saline-groundwater reinjection related to petroleum and natural-gas extraction in the Burbank Oil Field, Osage Nation, northeastern Oklahoma, 1950 through 2012.

[Saline-groundwater reinjection in million gallons per day]

\begin{tabular}{cccccc}
\hline Year & $\begin{array}{c}\text { Saline-groundwater } \\
\text { reinjection' }\end{array}$ & Year & $\begin{array}{c}\text { Saline-groundwater } \\
\text { reinjection' }\end{array}$ & Year & $\begin{array}{c}\text { Saline-groundwater } \\
\text { reinjection' }^{1}\end{array}$ \\
\hline 1950 & 130.55 & 1976 & $10,164.75$ & 2002 & $4,077.67$ \\
1951 & 715.57 & 1977 & $9,529.09$ & 2003 & $4,626.14$ \\
1952 & $1,505.98$ & 1978 & $8,840.70$ & 2004 & $4,656.09$ \\
1953 & $2,482.32$ & 1979 & $8,832.83$ & 2005 & $4,893.49$ \\
1954 & $1,884.33$ & 1980 & $8,298.53$ & 2006 & $5,080.51$ \\
1955 & $2,254.53$ & 1981 & $8,763.24$ & 2007 & $5,695.17$ \\
1956 & $2,663.06$ & 1982 & $8,573.18$ & 2008 & $6,418.81$ \\
1957 & $3,191.18$ & 1983 & $8,476.53$ & 2009 & $7,044.94$ \\
1958 & $3,996.98$ & 1984 & $8,014.47$ & 2010 & $7,203.63$ \\
1959 & $4,882.52$ & 1985 & $7,681.90$ & 2011 & $7,819.03$ \\
1960 & $6,290.91$ & 1986 & $4,094.40$ & 2012 & $8,373.68$ \\
1961 & $7,597.68$ & 1987 & $2,986.50$ & & \\
1962 & $9,026.83$ & 1988 & $2,825.12$ & & \\
1963 & $10,056.13$ & 1989 & $2,228.40$ & & \\
1964 & $11,236.65$ & 1990 & $1,947.50$ & & \\
1965 & $11,889.78$ & 1991 & $1,713.00$ & & \\
1966 & $11,932.87$ & 1992 & $1,761.06$ & & \\
1967 & $12,169.53$ & 1993 & $1,810.60$ & & \\
1968 & $11,380.70$ & 1994 & $1,647.73$ & & \\
1969 & $11,500.43$ & 1995 & 822.56 & & \\
1970 & $12,043.79$ & 1996 & $1,169.08$ & & \\
1971 & $11,849.06$ & 1997 & $1,974.32$ & & \\
1972 & $11,652.28$ & 1998 & $2,479.46$ & & \\
1973 & $11,511.42$ & 1999 & $2,819.36$ & & \\
1974 & $10,774.52$ & 2000 & $2,642.49$ & & \\
1975 & $10,395.00$ & 2001 & $3,299.99$ & & \\
\hline
\end{tabular}

'Erwin Pino, DeLon Flinchum, and Matt Stover, Chaparral Energy, Inc., written commun., 2013. 
(407,000 Mgal) of water, and minor bedrock aquifers were estimated to contain 9,464,000 acre-ft (3,080,000 Mgal) of freshwater in the Osage Nation (D.C. Kent, Oklahoma State University, written commun., 1992). Mashburn and others (2003) estimated that alluvial aquifers along the Arkansas River in the Osage Nation contained about 200,000 acre-ft (65,200 Mgal). D'Lugosz and others (1986) estimated that the Vamoosa-Ada aquifer contained about $36,000,000$ acre-ft $(11,700,000 \mathrm{Mgal})$ of freshwater, with the part of that aquifer in the Osage Nation being estimated by Shields (1993) to contain about 10,185,000 acre-ft (3,320,000 Mgal) of freshwater. Combining those estimates, which were based on previously published literature and USGS streamflow data for the Arkansas River, indicates that a range of about 29,600,000-41,200,000 acre-ft (9,640,000-13,400,000 Mgal) of freshwater is theoretically available for use in the Osage Nation in any given year. Those estimates, however, are upper limits, because sustainable water use would preclude withdrawing the total flow of the Arkansas River, the total volume of all water-supply lakes, and the freshwater contents of all aquifers in the Osage Nation in any given year, because such withdrawals would cause substantial deleterious effects on aquatic ecosystems, water-related tourism, property values, water quality (from increased upward seepage of underlying saline water), and water availability for public suppliers and agriculture. Assuming annual precipitation of 42 inches per year (fig. 2) and loss of half of that water to evapotranspiration, a maximum withdrawal of freshwater in the Osage Nation can be estimated to be 2,570,000 acre- $\mathrm{ft}$ or $838,000 \mathrm{Mgal}$ per year (Mgal/yr, or 2,294 Mgal/d). That maximum amount of withdrawal, based on net precipitation, however, would be likely to substantially reduce streamflows and lake levels, locally reduce fresh groundwater levels, and increase upward seepage of saline waters to streams and shallow aquifers. Annual estimated combined surface-water and groundwater withdrawals of 6,790 Mgal/yr (or 18.6 $\mathrm{Mgal} / \mathrm{d}$ from the 2010 annual total withdrawals) indicate that only about 1 percent of freshwater resources and the annual net precipitation is being withdrawn as freshwater. Determination of sustainable use of water resources in the Osage Nation can best be made with groundwater and surface-water models that simulate and can identify the effects of climate variations and changes in water withdrawals on freshwater and saline-water resources in the Osage Nation.

In addition to freshwater resources, much larger reserves of saline-water resources underlie the Osage Nation. The upper unit of the Western Interior Plains aquifer system underlying freshwater aquifers in Osage County, which corresponds to the Mississippian-age sedimentary formations shown in table 7, is about $150 \mathrm{ft}$ thick and contains groundwater with dissolved solids concentration larger than $35,000 \mathrm{mg} / \mathrm{L}$, which is considered to be a brine (Osborn and others, 2013). Lower units of that Western Interior Plains aquifer system, which consist of sedimentary formations of Late Cambrian through Ordovician ages of about 500-ft thickness also contain groundwater with dissolved solids concentration exceeding 35,000 mg/L (Osborn and others, 2013). Those generalized thicknesses, with the assumptions that those units underlie the entire extent of the Osage Nation and that porosities of those units average 0.15 (Freeze and Cherry, 1979; Christenson and others, 2011), indicate that 45,000,000 Mgal of brines may underlie the Osage Nation. At present, a small portion of those brines is a byproduct of petroleum and natural-gas extraction (produced water) that is reinjected into those deep strata to enhance petroleum extraction or is disposed into deeper strata. Such brines may be used for other purposes as desalinization technology continues to improve and becomes more economical (Osborn and others, 2013).

\section{Data Gaps}

Collection of additional hydrogeologic data could improve understanding of the water resources of the Osage Nation. Better understanding of streamflow, surface-waterquality variability and trends in time and place, and factors affecting surface-water quality could be provided by establishing long-term streamflow and water-quality sampling stations at (1) a site between Kaw Lake and the Arkansas River at Ralston, Okla., streamflow-gaging station, (2) a site on the Arkansas River downstream of Keystone Lake, (3) one or more sites in the Caney River Basin, and (4) a site in the Sand Creek Basin west of Bartlesville, Okla. Installation of continuous water-quality monitors for parameters such as turbidity, temperature, specific conductance, and dissolved oxygen concentration at one or more streamflow-gaging stations could provide additional information about daily and longer term changes in surface-water quality that cannot be determined from collection and measurement of a few waterquality samples per year.

Knowledge of fresh groundwater quantity and quality also is limited in the Osage Nation. Simulation of groundwater movement through freshwater aquifers underlying the Osage Nation with three-dimensional static and transient groundwater-flow models could improve knowledge of groundwater recharge and discharge and could be useful for testing scenarios of the effects of future projected climate conditions and changes in groundwater withdrawals on those water resources. Regular periodic sampling of a network of 20-30 wells completed in freshwater aquifers could provide better information about changes in groundwater elevations, groundwater-flow directions, and changes in groundwater quality with time and place in the Osage Nation. Installation of pressure transducers in several wells could provide additional information about seasonal changes in groundwater levels, aquifer recharge, seepage rates through the unsaturated zone, and other factors that may affect groundwater movement, quality, and availability in the Osage Nation. Gathering additional data about saline-groundwater reinjection and disposal in the Osage Nation from all petroleum and 
natural-gas fields could provide a better understanding of the uses and value of saline-water resources in this area.

Water-use data for Oklahoma generally are based on self-reported withdrawal numbers by water withdrawers and generalized coefficients of water use by humans, livestock, agriculture, and industry. Metering water use of various types at selected locations could enable more accurate estimates of water use in the Osage Nation.

Better understanding of aquifer properties and saline/ freshwater interfaces through geophysical surveys, which are being done in 2013-14 in the Osage Nation by the Osage Nation, the USGS, and others, could improve understanding of the permeability and related properties of aquifer materials, aquifer stratigraphy, and quantities and spatial distribution of fresh and saline-groundwater resources underlying the Osage Nation.

\section{Summary}

The Osage Nation of northeastern Oklahoma is characterized by gently rolling uplands, incised stream valleys, and underlying sedimentary rock units of Pennsylvanian through Permian age. Cattle ranching and petroleum and natural-gas extraction are the principal land uses in this rural area. Freshwater resources in the Osage Nation include water flowing in the Arkansas River and several smaller streams, water stored in several lakes, and groundwater stored in unconsolidated alluvial aquifers and bedrock aquifers, including the Pennsylvanian-age Vamoosa-Ada aquifer and minor bedrock aquifers. Fresh groundwater is underlain by saline groundwater in deeper aquifers underlying the Osage Nation. Such saline waters commonly are brought to the land surface as produced water and are reinjected to deep strata for petroleum extraction.

Water rights in tribal lands such as the Osage Nation are Federal reserved rights, which have limits. Such rights supersede other rights for water withdrawals that may be granted by States or other entities. There are sufficient water resources for current land uses and economic activities in most of the Osage Nation. Because of the potential for future population increases, demands for water from neighboring areas such as the Tulsa metropolitan area, and expansion of petroleum and natural-gas extraction affecting water resources, the U.S. Geological Survey (USGS), in cooperation with the Osage Nation, summarized existing hydrologic data and identified gaps in those data to facilitate better understanding of the water resources of this area for planning future development and water use.

Long-term streamflow measurements at several streamflow-gaging stations in or near the Osage Nation indicate that streamflows at several streamflow-gaging stations increased by as much as a factor of 2 during wetter periods from the 1970 s to 2000 , with subsequent decreases of as much as 50 percent during intermittent drier years of the early 2000s. Surface water generally contains sufficient concentrations of dissolved oxygen for survival of coldwater and warmwater aquatic biota. Water in several lakes sampled in the Osage Nation in 2011-12 by the Oklahoma Water Resources Board (OWRB) contained sufficient chlorophyll- $a$ concentrations to be ranked as mesotrophic to eutrophic, indicating water-quality impairment by nutrients. At sites sampled on Hominy Creek, Little Hominy Creek, and the Arkansas River, total dissolved solids concentrations exceeded the secondary drinking-water standard of 500 milligrams per liter $(\mathrm{mg} / \mathrm{L})$ in $25-75$ percent of surface-water samples, indicating limitations for supplying drinking water or other purposes. About 25 percent of the water samples collected by the Osage Nation at the Hominy Creek site and by the OWRB at the Arkansas River site contained dissolved chloride concentrations exceeding the secondary drinking-water standard of $250 \mathrm{mg} / \mathrm{L}$ set by the EPA. Chloride concentration in surface-water samples collected by the USGS tended to be larger in watersheds with greater densities of numbers of petroleum wells. Larger dissolved chloride concentrations at smaller streamflows at several sites indicated that groundwater seeping as base flow to streams in the Osage Nation can contain dissolved chloride concentrations that exceed the secondary drinking-water standard. Because of the relatively large dissolved chloride concentrations and large streamflows measured at the Arkansas River at Ralston, Okla., site, the greatest dissolved chloride loads were measured at that site. The largest dissolved chloride yields were measured for the watershed upstream of the Little Hominy Creek site. Dissolved phosphorus concentration was significantly larger in surface-water samples collected at the Arkansas River at Ralston, Okla., site than in surface-water samples collected at the Bird Creek at Avant, Okla., site. Relatively large dissolved phosphorus concentrations compared to water-quality standards indicate that eutrophication can occur in these streams (usually dominated by periphyton, algae growing on solid surfaces) or in lakes receiving these waters (usually dominated by phytoplankton, algae growing predominantly near the top of the water column).

Groundwater also is an important source of water for the Osage Nation, which is underlain by three principal freshwater aquifers: (1) alluvial aquifers, consisting of unconsolidated sands, silts, clays, and gravels deposited along streams and rivers; (2) the Vamoosa-Ada aquifer, consisting of a sequence of sandstones, limestones, and shales; and (3) minor bedrock aquifers associated with shales, sandstones, and limestones. The amount of potable groundwater stored in the alluvial aquifers and the Vamoosa-Ada aquifer is adequate for current domestic and other purposes, but in areas where these aquifers are absent, groundwater must be pumped from minor bedrock aquifers that produce smaller amounts of water. About 30 percent of water samples collected from alluvial aquifers and 60 percent of water samples collected from the VamoosaAda aquifer contained total dissolved solids concentrations larger than the secondary drinking-water standard of $500 \mathrm{mg} / \mathrm{L}$, indicating potential limitation of use of water from 
those aquifers in some areas. Local factors, such as natural seepage of brines up into fresh groundwater or leaks and spills from petroleum and natural-gas extraction activities conducted near the land surface, appear to cause substantial variations in dissolved chloride concentration in groundwater in the Osage Nation. Groundwater underlying freshwater aquifers in the Osage Nation can contain substantial concentrations of chloride. Total phosphorus concentrations measured in groundwater samples collected in the Osage Nation were similar to dissolved phosphorus concentrations measured in water samples collected at the Bird Creek at Avant, Okla., and the Arkansas River at Ralston, Okla., sites at smaller streamflows, indicating that local groundwater may be affected by phosphorus seeping into alluvial materials from surface water and also may be a source of phosphorus discharging to local streams.

Fresh surface-water and groundwater withdrawals (use) in the Osage Nation were estimated at 5-year intervals from 1890 to 2010 on the basis of population estimates of humans and livestock, previous estimates of water use from 1985 through 2010, linear regression, and coefficients. Fresh surface-water use and fresh groundwater use were estimated to increase from 0.75 to 16.19 million gallons per day (Mgal/d) and from 0.13 to $2.39 \mathrm{Mgal} / \mathrm{d}$, respectively, for the 1890-2010 period. Predominant fresh surface-water uses and groundwater uses in 2010 were for public water supply, livestock, and industrial self-supplied purposes. Annual estimates of quantities of saline groundwater reinjected into petroleum and natural-gas producing zones after withdrawals from the heavily developed Burbank Oil Field from 1950 through 2012 indicate that much more saline water is used in Osage County than freshwater, with recent increases in use of saline water occurring in the 2000s. Additional large amounts of saline water probably are withdrawn from numerous other producing fields in the Osage Nation during extraction of petroleum and natural gas.

Estimates of freshwater resources in local streams, lakes, and freshwater aquifers and of net annual precipitation indicate that less than 1 percent of freshwater resources and net annual precipitation is being withdrawn annually in the Osage Nation. Generalized estimates of thickness and porosity of brine-filled aquifers indicate that the Osage Nation may be underlain by $45,000,000$ million gallons of brines.

Additional measurement, sampling, and analyses of water resources in the Osage Nation could improve understanding about those resources and the ability to manage them. Simulation of groundwater movement through freshwater aquifers underlying the Osage Nation with three-dimensional static and transient groundwater-flow models could improve knowledge of groundwater recharge and discharge and be useful for testing scenarios of the effects of future projected climate conditions and changes in groundwater withdrawals. Additional long-term streamflow and water-quality sampling stations, some with continuous water-quality monitors, could expand and improve understanding of surface-water quality in time and place in the Osage Nation. Regular periodic measurement of water levels and water-quality sampling of wells completed in freshwater aquifers could provide additional information about trends of groundwater quantity and quality in time and place in the Osage Nation. More accurate monitoring of the use of fresh and saline water at selected sites could enable more refined estimates of water use across the Osage Nation. Better understanding of aquifer properties and saline/freshwater interfaces through geophysical surveys could improve understanding of aquifer properties and the spatial distribution of fresh and saline groundwater resources underlying the Osage Nation.

\section{References Cited}

Abbott, M.M., 2000, Water quality of the Quaternary and Ada-Vamoosa Aquifers on the Osage Reservation, Osage County, Oklahoma, 1997: U.S. Geological Survey WaterResources Investigations Report 99-4231, 76 p.

Abbott, M.M., Runkle, Donna, and Rea, Alan, 1997, Digital data sets that describe aquifer characteristics of the Vamoosa-Ada aquifer in east-central Oklahoma: U.S. Geological Survey Open-File Report 96-444, 1:250,000 scale.

Abbott, M.M., and Tortorelli, R.L., 2002, Surface-water characteristics and quality on the Osage Reservation, Osage County, Oklahoma, 1999: U.S. Geological Survey WaterResources Investigations Report 02-4060, 68 p.

Andrews, W.J., Becker, M.F., Smith, S.J., and Tortorelli, R.L., 2009 , Summary of surface-water quality data from the Illinois River Basin in northeast Oklahoma, 1970-2007: U.S. Geological Survey Scientific Investigations Report 2009-5182, $39 \mathrm{p}$.

Beckwith, H.T., 1928, Oil and gas in Oklahoma, geology of Osage County: Oklahoma Geological Survey Bulletin No. 40-T, 62 p.

Bein, Amos, and Dutton, A.R., 1993, Origin, distribution, and movement of brine in the Permian Basin (U.S.A.)-A model for displacement of connate brine: Geological Society of America Bulletin, v. 105, no. 6, p. 695-707.

Bingham, R.H., and Bergman, D.L., 1980, Reconnaissance of the water resources of the Enid Quadrangle north-central Oklahoma: Oklahoma Geological Survey, Hydrologic Atlas 7,4 sheets.

Bourlier, B.G., Nichols, J.D., Ringwald, W.J., Workman, P.J., and Clemmons, Stanley, 1979, Soil survey of Osage County, Oklahoma: Soil Conservation Service and Bureau of Indian Affairs, variously paged, accessed January 12, 2014, at http://www.nrcs.usda.gov/Internet/FSE MANUSCRIPTS/oklahoma/osageOK1979/osageOK̄ 1979. pdf. 
Boyd, D.T., 2002, Oklahoma oil and gas fields: Oklahoma Geological Survey Geologic Map 36. [Also available at http://www.ogs.ou.edu/level3-oilgas.php.]

Boyd, D.T., 2011, Oklahoma 2010 drilling highlights: The Shale Shaker, v. 61, no. 5, p. 293-305.

Bureau of the Census, 1927, United States Census of Agriculture - 1925, reports for States, with statistics for counties and a summary for the United States, part II, the Southern States: Bureau of the Census, 96 p.

Bureau of the Census, 1936, United States Census of Agriculture - 1935, reports for States with statistics for counties and a summary for the United States, Oklahoma, v. 1, part 2: Bureau of the Census, 947 p.

Bureau of the Census, 1942, United States Census of Agriculture - 1940, reports for States with statistics for counties and a summary for the United States, Oklahoma, v. 1, part 2: Bureau of the Census, $638 \mathrm{p}$.

Bureau of the Census, 1946, United States Census of Agriculture-1945, Oklahoma, statistics for counties, v. 1, part 25: Bureau of the Census, 204 p.

Bureau of the Census, 1952, United States Census of Agriculture-1950, v. 1, counties and State economic areas, part 25, Oklahoma: Bureau of the Census, $325 \mathrm{p}$.

Bureau of the Census, 1956, United States Census of Agriculture-1954, v. 1, counties and State economic areas, part 25, Oklahoma: Bureau of the Census, 312 p.

Bureau of the Census, 1961, United States Census of Agriculture-1959, final report, v. 1, part 36, Oklahoma counties: Bureau of the Census, 299 p.

Bureau of the Census, 1967, 1964 Census of Agriculture, Oklahoma State and county data, v. 1, part 36: Bureau of the Census, 997 p.

Bureau of the Census, 1972, 1969 Census of Agriculture, Oklahoma State and county data, v. 1, part 36: Bureau of the Census, 997 p.

Bureau of the Census, 1977, 1974 Census of Agriculture, Oklahoma State and county data, v. 1, part 36: Bureau of the Census, $760 \mathrm{p}$.

Bureau of the Census, 1982, Preliminary estimates of the intercensal population of counties, 1970-1979: Bureau of the Census, accessed June 20, 2013, at http://www.census. gov/popest/data/counties/totals/pre-1980/tables/e7079co.txt.

Bureau of the Census, 1984, 1982 Census of Agriculture, Oklahoma State and county data, v. 1, part 36: Bureau of the Census, 444 p.

Bureau of the Census, 1989, 1987 Census of Agriculture, Oklahoma State and county data, v. 1, part 36: Bureau of the Census, 492 p.
Bureau of the Census, 1992, Intercensal estimates of the resident population of States and counties, 1980-1989: Bureau of the Census, accessed June 20, 2013, at http:// www.census.gov/popest/data/historical/1980s/county.html.

Bureau of the Census, 1994, 1992 Census of Agriculture, Oklahoma State and county data, v. 1, part 36: Bureau of the Census, $480 \mathrm{p}$.

Bureau of the Census, 1999, 1997 Census of Agriculture, Oklahoma State and county data, Geographic Area Series Part 36: Bureau of the Census, AC-97-A-36, v. 1, 491 p.

Bureau of the Census, 2002, Resident population and apportionment of the U.S. House of Representatives: Bureau of the Census, accessed June 20, 2013, at http:// www.census.gov/dmd/www/resapport/states/oklahoma.pdf.

Bureau of the Census, 2004, 2002 Census of Agriculture, Oklahoma State and county data, Geographic Area Series Part 36: Bureau of the Census, AC-02-A-36, v. 1, 611 p.

Bureau of the Census, 2009, 2007 Census of Agriculture, Oklahoma State and county data, Geographic Area Series Part 36: Bureau of the Census, AC-07-A-36, v. 1, 683 p.

Carlucci, J.R., and Westrop, S.R., 2009, Sequence stratigraphy and facies architecture of the Bromide Formation (Upper Ordovician; Sandbian) of Oklahoma: Portland, Oreg., Geological Society of America Paper no. 36-5, 1 p.

Cartwright, Ian, Weaver, T.R., Cendon, D.I., Fifield, L.K., Tweed, S.O., Petrides, Ben, and Swain, Ian, 2012, Constraining groundwater flow, residence times, interaquifer mixing, and aquifer properties using environmental isotopes in the southeast Murray Basin, Australia: Applied Geochemistry, v. 27, no. 9, p. 1698-1700.

Chapman, Gary, 1986, Ambient water quality criteria for dissolved oxygen: U.S. Environmental Protection Agency, EPA 440/5-85-003, 46 p.

Christenson, Scott, Osborn, N.I., Neel, C.R., Faith, J.R., Blome, C.D., Puckette, James, and Pantea, M.P., 2011, Hydrogeology and simulation of groundwater flow in the Arbuckle-Simpson aquifer, south-central Oklahoma: U.S. Geological Survey Scientific Investigations Report 20115029, 104 p.

Cleveland, W.S., and Devlin, S.J., 1988, Locally-weighted regression-An approach to regression analysis by local fitting: Journal of American Statistical Association, v. 83, p. 596-610.

Cohen, F.S., 1982, Felix S. Cohen's handbook of Federal Indian law: Charlottesville, Va., Lexis Law Publishing, $912 \mathrm{p}$.

Cohn, T.A., 1988, Adjusted maximum likelihood estimation of the moments of lognormal populations from Type 1 censored samples: U.S. Geological Survey Open-File Report 88-350, 34 p. 
Collins, A.G., 1974, Saline groundwaters produced with oil and gas: U.S. Environmental Protection Agency, Report EPA-660/2-74-010, 68 p.

Colorado Geological Survey, 2008, Ground water atlas of Colorado: Colorado Geological Survey, accessed August 9, 2013, at http://geosurvey.state.co.us/water/ GroundwaterAtlas/Pages/GroundwaterAtlasofColorado. aspx.

Cushman, R.C., 2004, Peterson Field Guides-The North American prairie: Boston, Mass., Houghton Mifflin Harcourt, 528 p.

DeHay, K.L., Andrews, W.J., and Sughru, M.P., 2004, Hydrology and ground-water quality in the mine workings within the Picher mining district, northeastern Oklahoma, 2002-03: U.S. Geological Survey Scientific Investigations Report 2004-5043, 62 p.

D’Lugosz, J.J., McClaflin, R.G., and Marcher, M.V., 1986, Geohydrology of the Vamoosa-Ada aquifer east-central Oklahoma: Oklahoma Geological Survey Circular 87, 42 p.

Domalgalski, J.L., and Johnson, Henry, 2012, Phosphorus and groundwater-Establishing links between agricultural use and transport to streams: U.S. Geological Survey Fact Sheet 2012-3004, 4 p.

Drever, J.I., 1988, The geochemistry of natural waters (2d ed.): Englewood Cliffs, N.J., Prentice Hall, 437 p.

Environmental Systems Research Institute, Inc., 2012, Zonal Statistics as Table (Spatial Analyst): Environmental Systems Research Institute, Inc., ArcGIS Resource Center, Desktop 10, accessed December 9, 2013, at http:// help.arcgis.com/en\%20/arcgisdesktop/10.0/help/index. html\#//009z000000w8000000.htm.

Environmental Systems Research Institute, Inc., 2013, Shaded relief: Environmental Systems Research Institute, Inc., accessed September 11, 2013, at http://www.arcgis.com/ home/item.html?id=7fcb19a848f0497c940b2c7370afba06.

Esralew, R.A., Andrews, W.J., Allen, M.L., and Becker, C.J., 2012, Comparison of load estimation techniques and trend analysis for nitrogen, phosphorus, and suspended sediment in the Eucha-Spavinaw Basin, northwestern Arkansas and northeastern Oklahoma, 2002-10: U.S. Geological Survey Scientific Investigations Report 2011-5172, 60 p.

Esralew, R.A., Andrews, W.J., and Smith, S.J., 2011, Evaluation and trends of land cover, streamflow, and water quality in the North Canadian River Basin near Oklahoma City, Oklahoma, 1968-2009: U.S. Geological Survey Scientific Investigations Report 2011-5117, 97 p.

Fenneman, N.M., and Johnson, D.W., 1946, Physical divisions of the conterminous United States: U.S. Geological Survey, 1 sheet, scale 1:7,000,000.
Forstall, R.L., 1995, Oklahoma, population of counties by decennial census - 1900 to 1990: U.S. Bureau of the Census, accessed June 20, 2013, at http:/www.census.gov/ population/cencounts/ok190090.txt.

Franks, K.A., 1989, The Osage oil boom: Oklahoma City, Oklahoma Heritage Association, 180 p.

Freeze, R.A., and Cherry, J.A., 1979, Groundwater: Englewood Cliffs, N.J., Prentice-Hall, Inc., 604 p.

Fry, J.A., Cian, George, Jin, Suming, Dewitz, J.A., Homer, C.G., Yang, Limin, Barnes, C.A., Herald, N.D., and Wickham, J.D., 2011, Completion of the 2006 National Land Cover Database for the conterminous United States: Photogrammetric Engineering and Remote Sensing, v. 77, no. 9, p. 858-866.

Graham, J.L., Loftin, K.A., Ziegler, A.C., and Meyer, M.T., 2008, Guidelines for design and sampling for cyanobacterial toxin and taste-and-odor studies in lakes and reservoirs: U.S. Geological Survey Scientific Investigations Report 2008-5308, 39 p.

Helsel, D.R., and Hirsch, R.M., 2002, Statistical methods in water resources: New York, Elsevier, 522 p.

Helton, Taiawagi, 1998, Indian reserved water rights in the dual-system State of Oklahoma: Tulsa Law Review, v. 33, issue 3, p. 979-1002.

Heran, W.D., Green, G.N., and Stoeser, D.B., 2003, A digital geologic map database for the State of Oklahoma: U.S. Geological Survey Open-File Report 2003-247. [Also available at http://pubs.usgs.gov/of/2003/ofr-03-247/.]

Huggins, D.G., and Anderson, Jeff, 2005, Dissolved oxygen fluctuation regimes in streams of the western corn belt plains ecoregion: Kansas Biological Survey Report no. 130, $57 \mathrm{p}$.

Johnson, K.S., 1983, Maps showing principal ground-water resources and recharge areas in Oklahoma: Oklahoma State Department of Health, 2 sheets, scale 1:500,000.

Kharaka, Y.K., and Otton, J.K., eds., 2003, Environmental impacts of petroleum production-Initial results from the Osage-Skiatook Petroleum Environmental Research Sites, Osage County, Oklahoma: U.S. Geological Survey WaterResources Investigations Report 03-4260, 155 p.

Langbein, W.B., and Iseri, K.T., 1960, General introduction and hydrologic definitions-Manual of hydrology-Part 1. General surface-water techniques: U.S. Geological Survey Water-Supply Paper 1541-A, 29 p.

Lee, Wallace, Leatherock, Constance, and Botinelly, Theodore, 1948, The stratigraphy and structural development of the Saline Basin of Kansas: State Geological Survey of Kansas Bulletin 74, 155 p. 
MacKichan, K.A., 1957, Estimated use of water in the United States, 1955: U.S. Geological Survey Circular 398, 18 p.

MacKichan, K.A., and Kammerer, J.C., 1961, Estimated use of water in the United States, 1960: U.S. Geological Survey Circular 456, $44 \mathrm{p}$.

Madsen, John, and Oberle, Frank, 1993, Tallgrass prairie: Kingwood, Tex., Falcon Press Publishing Company, 112 p.

Mashburn, S.L., Cope, C.C., and Abbott, M.M., 2003, Aquifer characteristics, water availability, and water quality of the Quaternary aquifer, Osage County, northeastern Oklahoma, 2001-2002: U.S. Geological Survey Water-Resources Investigations Report 03-4235, $41 \mathrm{p}$.

McElroy, M.B., and Lu, Xi, 2013, Fracking's future-Natural gas, the economy, and America's energy prospects: Harvard Magazine, Nov.-Dec. 2013, accessed December 9, 2013, at http://harvardmagazine.com/2013/01/frackings-future.

Morel, F.M.M., and Hering, J.G., 1993, Principles and applications of aquatic chemistry: New York, John Wiley and Sons, Inc., $588 \mathrm{p}$.

Murray, C.R., 1968, Estimated use of water in the United States, 1965: U.S. Geological Survey Circular 556, 53 p.

Murray, C.R., and Reeves, E.B., 1972, Estimated use of water in the United States in 1970: U.S. Geological Survey Circular 676, $37 \mathrm{p}$.

Murray, C.R., and Reeves, E.B., 1977, Estimated use of water in the United States in 1975: U.S. Geological Survey Circular 765, $39 \mathrm{p}$.

Murray, K.E., 2013, State-scale perspective on water use and production associated with oil and gas operations, Oklahoma, U.S.: Environmental Science and Technology, v. 47 , p. $4918-4925$.

National Agricultural Statistics Service, 2011, Oklahoma agricultural statistics, 2011: National Agricultural Statistics Service, $86 \mathrm{p}$.

National Oceanic and Atmospheric Administration, 2013, Climate data online - Search tool: National Oceanic and Atmospheric Administration, National Climatic Data Center, accessed August 6, 2013, at http://www.ncdc.noaa. gov/cdo-web/search.

Natural Resources Conservation Service, 2006, Digital general soil map of the United States: Natural Resources Conservation Service, accessed February 13, 2012, at http://soildatamart.nrcs.usda.gov.

Natural Resources Conservation Service, 2013, Geospatial Data Gateway: Natural Resources Conservation Service, accessed March 14, 2013, at http://datagateway.nrcs.usda. gov/.
Natural Resources Conservation Service, 2014, The soil orders of Texas: Natural Resources Conservation Service, accessed March 13, 2014, at http://www.nrcs.usda.gov/wps/portal/ $\mathrm{nrcs} /$ detail/tx/soils/?cid=nrcs144p2_003094.

New Mexico Office of the State Engineer, 1999, Glossary of water terms: New Mexico Office of the State Engineer, accessed August 9, 2013, at http://www.ose.state.nm.us/ water_info_glossary.html.

Oklahoma Climatological Survey, 2013, The climate of Osage County: Oklahoma Climatological Survey, accessed August 8, 2013, at http://climate.ok.gov/county_climate/Products/ County_Climatologies/county_climate_osage.pdf.

Oklahoma Historical Society, 2013, Irrigation: Oklahoma Historical Society, accessed July 2, 2013, at http://digital. library.okstate.edu/encyclopedia/entries/I/IR003.html.

Oklahoma Water Resources Board, 1998, Rural water systems in Oklahoma: Oklahoma Water Resources Board, 212 p.

Oklahoma Water Resources Board, 2013a, GroundwaterData and maps: Oklahoma Water Resources Board, accessed May 8, 2013, at http://www.owrb.ok.gov/maps/ pmg/owrbdata_GW.html.

Oklahoma Water Resources Board, 2013b, Results for station ID 621200010200-001AT: Oklahoma Water Resources Board, accessed July 19, 2013, at http://www.owrb.ok.gov/ maps/data/wqdatagrid.php?SID=621200010200-001AT.

Oklahoma Water Resources Board, 2013c, 2012 Oklahoma lakes report: Oklahoma Water Resources Board, accessed October 18, 2013, at http://www.owrb.ok.gov/quality/ monitoring/bump/pdf_bump/Current/Lakes/2012_ LakesBUMPReport.pdf.

Omernik, J.M., 1987, Ecoregions of the conterminous United States: Annals of the Association of American Geographers, v. 77 , no. 1 , p. $118-125$.

Osage Nation, 2006, Osage Nation historic reservationInformation: Osage Nation, accessed August 7, 2013, at http://www.osagetribe.com/historicpreservation/info_sub_ page.aspx?subpage_id $=14$.

Osborn, N.I., Smith, S.J., and Seger, C.H., 2013, Hydrogeology, distribution, and volume of saline groundwater in the southern midcontinent and adjacent areas of the United States: U.S. Geological Survey Scientific Investigations Report 2013-5017, 58 p.

Rantz, S.E., and others, 1982, Measurement and computation of streamflow-Volume 2, computation of discharge: U.S. Geological Survey Water-Supply Paper 2175, v. 2, 285 p.

Shields, R.H., Jr., 1993, A water resources management strategy for surface and groundwater in Osage County, Oklahoma utilized to formulate policy guidelines for water rights and resources protection and management for Indian lands: Oklahoma State University, Ph.D. dissertation, 161 p. 
Shivers, M.J., and Andrews, W.J., 2013, Hydrologic drought of water year 2011 compared to four major drought periods of the 20th century in Oklahoma: U.S. Geological Survey Scientific Investigations Report 2013-5018, 52 p.

Solley, W.B., Chase, E.B., and Mann, W.B., IV, 1983, Estimated use of water in the United States in 1980: U.S. Geological Survey Circular 1001, 56 p.

Solley, W.B., Merk, C.F., and Pierce, R.R., 1988, Estimated use of water in the United States in 1985: U.S. Geological Survey Circular 1004, 82 p.

Solley, W.B., Pierce, R.R., and Perlman, H.A., 1993, Estimated use of water in the United States in 1990: U.S. Geological Survey Circular 1081, 76 p.

State of Oklahoma, 2006, Implementation of Oklahoma's water quality standards, chap 46 of State of Oklahoma, Title 785, Oklahoma Water Resources Board, unofficial 785:46, 44 p., accessed December 15, 2011, at http://www.owrb. ok.gov/util/rules/pdf_rul/Chap46.pdf.

State of Wisconsin, 2010, Chapter NR102. Water quality standards for Wisconsin surface waters: State of Wisconsin Register, November 2010, no. 659, 22 p.

TIBCO Software Incorporated, 2008, TIBCO Spotfire S-Plus version 8.1.1 for Microsoft Windows professional developer edition with release 4.0 of the U.S. Geological Survey S-PLUS library: Palo Alto, Calif., TIBCO Software Incorporated.

Tortorelli, R.L., 2008, Hydrologic drought of water year 2006 compared with four major drought periods of the 20th century in Oklahoma: U.S. Geological Survey Scientific Investigations Report 2008-5199, 46 p.

Tortorelli, R.L., 2009, Water use in Oklahoma 1950-2005: U.S. Geological Survey Scientific Investigations Report 2009-5212, 50 p.

U.S. Census Bureau, 2000, Cartographic boundary filesPlaces (incorporated places and census designated places): U.S. Census Bureau, accessed February 13, 2013, at http:// www.census.gov/geo/maps-data/data/cbf/cbf_place.html.

U.S. Census Bureau, 2013, 2010 census: U.S. Census Bureau, accessed August 6, 2013, at www.census.gov/2010census/.

U.S. Census Office, 1895, Report on the statistics of agriculture in the United States at the Eleventh Census-1890: U.S. Census Office, 606 p.

U.S. Census Office, 1902, Twelfth Census of the United States taken in the year 1900, agriculture: United States Census Office, Census Reports v. 5, part 1, 767 p.

U.S. Energy Information Administration, 2013, Cushing, OK WTI spot Price FOB: U.S. Energy Information Administration, accessed December 9, 2013, at http://www.eia.gov/dnav/pet/hist/LeafHandler. $\operatorname{ash} \mathrm{x} ? \mathrm{n}=\mathrm{PET} \& \mathrm{~s}=\mathrm{RWTC} \& \mathrm{f}=\mathrm{A}$.
U.S. Environmental Protection Agency, 2013a, STORET Data Warehouse access: U.S. Environmental Protection Agency, accessed July 18, 2013, at http://www.epa.gov/storet/dbtop. html.

U.S. Environmental Protection Agency, 2013b, Secondary drinking water regulations - Guidance for nuisance chemicals: U.S. Environmental Protection Agency, accessed July 19, 2013, at http://water.epa.gov/drink/contaminants/ secondarystandards.cfm.

U.S. Geological Survey, 2006, Collection of water samples, chap. A4 of National field manual for the collection of water-quality data: U.S. Geological Survey Techniques of Water-Resources Investigations, book 9, chap. A4, 166 p., accessed March 17, 2014, at http://water.usgs.gov/owq/ FieldManual/chapter4/pdf/Chap4_v2.pdf.

U.S. Geological Survey, 2012, Multi-resolution land cover database: U.S. Geological Survey, accessed June 6, 2012, at http://www.mrlc.gov.

U.S. Geological Survey, 2013a, National Map Viewer: U.S. Geological Survey, accessed March 20, 2013, at http://viewer.nationalmap.gov/viewer/.

U.S. Geological Survey, 2013b, USGS water data for Oklahoma: U.S. Geological Survey National Water Information System, accessed November 13, 2013, at http://nwis.waterdata.usgs.gov/ok/nwis/.

U.S. Geological Survey, 2013c, Publications-Estimated use of water in the United States: U.S. Geological Survey, accessed June 20, 2013, at http://water.usgs.gov/ watuse/50years.html.

U.S. Geological Survey, 2013d, USGS water use data for the Nation: U.S. Geological Survey, accessed June 20, 2013, at http://waterdata.usgs.gov/nwis/wu.

U.S. Geological Survey, 2013e, Environmental impacts associated with disposal of saline water produced during petroleum production - Osage-Skiatook Petroleum Environmental Research Project: U.S. Geological Survey, accessed July 8, 2013, at http://toxics.usgs.gov/sites/ produced_water/.

U.S. Geological Survey, 2013f, Produced waters database: U.S. Geological Survey, accessed September 20, 2013, at http://energy.cr.usgs.gov/prov/prodwat/data2.htm.

U.S. Geological Survey, 2013g, The water cycleGroundwater discharge: U.S. Geological Survey, accessed August 1, 2013, at http://ga.water.usgs.gov/edu/ watercyclegwdischarge.html.

U.S. Oil and Gas Corporation, 2008, Oil production and secondary recovery: U.S. Oil and Gas Corporation, accessed July 8, 2013, at http://www.usoilandgas.net/oilproduction. $\mathrm{htm}$. 
Watkins, Kevin, Carvajal, Liliana, Coppard, Daniel, Fuentes, Ricardo, Ghosh, Arunabha, Ciamberardine, Chiara, Johansson, Claes, Seck, Pape, Ugaz, Cecilia, and Yaqub, Shanin, 2006, Human development report 2006, beyond scarcity-Power, poverty, and the global water crisis: United Nations Development Programme, 424 p.

Wilcoxon, Frank, 1945, Individual comparisons by ranking methods: Biometrics Bulletin, v. 1, no. 6, p. 80-83.
World Water Council, 2014, Water crises-Towards a way to improve the situation: World Water Council, accessed March 13, 2014, at http://worldwatercouncil.org/index. php?id $=25$.

Zouari, Kamel, Travelsi, Rim, and Chkir, Najiba, 2011, Using geochemical indicators to investigate groundwater mixing and residence time in the aquifer system of Djeffara of Medenine (southeastern Tunisia): Hydrogeology Journal, v. 19 , no. 1 , p. 209-219. 


\section{Glossary}

aquatic Life forms or substances in water.

aquifer A geologic formation, group of formations, or part of a formation that contains sufficient saturated permeable material to yield large quantities of water to wells and springs (New Mexico Office of the State Engineer, 1999).

base flow Streamflow derived from groundwater seepage; synonymous with "low flow."

climate The sum total of the meteorological elements that characterize the average and extreme condition of the atmosphere during a long period of time at any one place or region of Earth's surface (Langbein and Iseri, 1960).

concentration The mass of a substance dissolved per unit volume of liquid or contained in a unit mass of solid.

criterion A number or narrative statement assigned to protect a designated beneficial use. A water-quality standard set by the State.

cubic feet per second ( $\left.\mathrm{ft}^{\mathbf{3}} / \mathbf{s}\right) \quad$ A unit expressing rates of discharge. One cubic foot per second is equal to the discharge of a stream of rectangular cross section, 1 foot wide and 1 foot deep, with water flowing at an average velocity of 1 foot per second (Langbein and Iseri, 1960).

domestic water use Water used for normal household purposes, such as drinking, food preparation, bathing, washing clothes and dishes, flushing toilets, and watering lawns and gardens.

ecosystem A natural unit including all life forms and nonliving physical elements that function together.

eutrophication Nutrient enrichment (particularly of nitrogen and phosphorus) in aquatic ecosystems that leads to increased productivity, including excessive growth of algae and other aquatic plants (Graham and others, 2008). Excessive eutrophication changes aquatic habitat by changes in dissolved oxygen concentration, water temperature, availability of spawning beds, and visibility for predator fish. Aesthetic effects of hypereutrophication include degradation of water quality for swimming and other recreational activities and increases in concentrations of taste- and odor-producing organic compounds in drinking water.

irrigation water use Application of water on lands to assist in the growing of crops and pastures or maintaining recreational lands such as parks and golf courses.

load The mass of a substance flowing past a given point in a stream per unit of time, derived from multiplying streamflow by the aqueous concentration of a substance by unit correction factors. Loads are typically expressed in pounds or kilograms per day. milligrams per liter (mg/L) Milligrams of a substance dissolved in 1 liter of water; that is, the same as a part per million in freshwater because 1 liter of distilled water weighs 1 million milligrams (1 kilogram). This measure is equivalent to parts per million ( $\mathrm{ppm}$ ) (Colorado Geological Survey, 2008).

mining water use Water used in the extraction of naturally occurring minerals such as coal and ores, crude petroleum, and natural gas. Also includes quarrying, well operation, milling, and other preparation at a mine site.

precipitation Includes atmospheric hail, mist, rain, sleet, and snow that descend upon Earth; the quantity of water accumulated from these events (New Mexico Office of the State Engineer, 1999).

public supply Water withdrawn for all uses by public and private water suppliers and delivered to users that do not supply their own water. Water suppliers provide water for a variety of uses such as domestic, commercial, and industrial.

recharge Addition of water to an aquifer by infiltration, either directly into the aquifer or indirectly through another rock formation. Recharge may be natural, as when precipitation infiltrates to the water table, or artificial, as when water is injected through wells or spread over permeable surfaces for the purpose of recharging an aquifer (modified from New Mexico Office of the State Engineer, 1999).

reinjection water Water injected into an aquifer or an unsaturated porous formation after having been withdrawn in the course of oil extraction.

runoff That part of the precipitation that appears in surface streams (Langbein and Iseri, 1960).

saline water Water that contains more than 1,000 milligrams per liter of dissolved solids.

self-supplied water Water withdrawn from a surface-water or groundwater source by a user and not obtained from a public supply.

streamflow Discharge in a natural channel of the course of a surface stream (New Mexico Office of the State Engineer, 1999).

streamflow-gaging station A device used to measure and record the elevation of water in a stream or lake in a semicontinuous manner. In a flowing stream, comparisons of measured streamflows to surface-water elevations are used to estimate streamflow, commonly at 15 -minute intervals.

thermoelectric power Electrical power generated by using fossil-fuel, geothermal, or nuclear energy.

withdrawal Water removed from the ground or diverted from a surface-water source for use. 
yield The mass of a substance flowing past a given point in a stream per unit of time divided by the land area of the upstream watershed area. Yields are used to estimate relative contributions of constituents in surface water from particular watershed areas. 



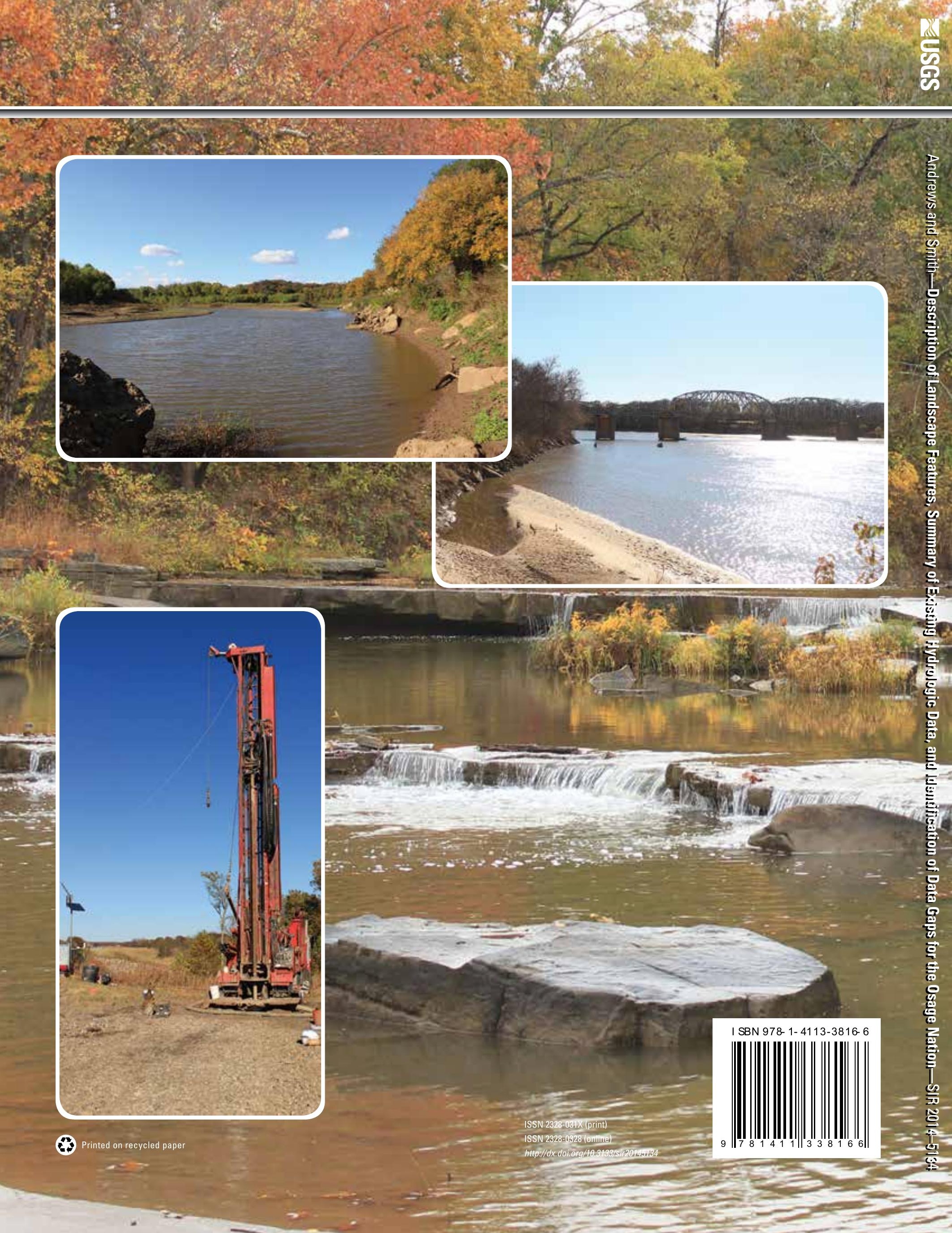

